\title{
Deciphering Isotopic Signals of Monsoon-Induced Upwelling in Foraminifera from the Western Arabian Sea sediment trap
}

by

\section{Dana Ruth Stuart}

B. S., The University of Michigan (1993).

Submitted in partial fulfillment of the requirements for the degree of

\section{MASTER OF SCIENCE}

at the

\section{MASSACHUSETTS INSTITUTE OF TECHNOLOGY \\ and the}

\section{WOODS HOLE OCEANOGRAPHIC INSTITUTION}

March, 1997

(C) Dana Ruth Stuart, 1997. All rights reserved

The author hereby grants to MIT and WHOI permission to reproduce and to distribute copies of this thesis document in whole or in part.

Signature of Author

$$
\text { Joint Program in Oceanogrąphy }
$$

Massachusetts Institute of Technology

Woods Hole Oceanographic Institution March 7, 1997

\section{A}

Certified by

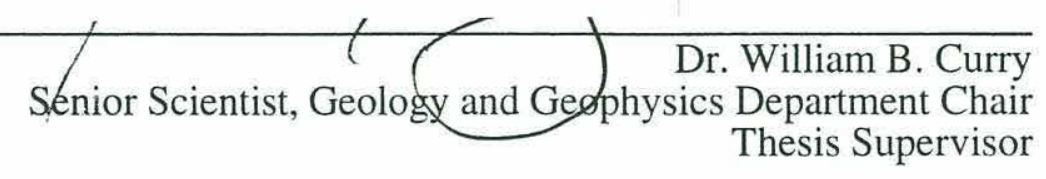

Accepted by

Dr. Deborah K. Smith

Chair, Joint Committee for Marine Geology and Geophysics Massachusetts Institute of Technology

Woods Hole Oceanographic Institution 


\title{
DECIPHERING ISOTOPIC SIGNALS OF MONSOON-INDUCED UPWELLING IN FORAMINIFERA FROM THE WESTERN ARABIAN SEA SEDIMENT TRAP \\ by

\author{
Dana Ruth Stuart
}

\author{
Submitted to the Department of Earth, Atmospheric, and Planetary Sciences \\ Massachusetts Institute of Technology \\ and \\ Department of Geology and Geophysics \\ Woods Hole Oceanographic Institution \\ March, 1997 \\ in partial fulfillment of the requirements \\ for the degree of Master of Science
}

\begin{abstract}
Isotopic analyses have been made on four species of foraminifera collected with a PARFLUX Mark VI sediment trap in the Arabian Sea during the 1986 and 1987 monsoons. Two of the species are non-spinose thermocline dwellers (Neogloboquadrina dutertrei, Globorotalia menardii) and two are spinose surface dwellers (Globigerinoides sacculifer, Globigerina bulloides). Individual tests were measured for shape, and analyzed for carbon and oxygen isotopes to document how each species responded to phases of the upwelling system, and to determine the utility of these planktonic foraminifera as upwelling indicators. The oxygen isotopic composition of the two thermocline dwellers remained fairly constant during the seasonal monsoon cycle, showing little to no effect from upwelling whereas the surface dwellers exhibited a wider range of $\delta^{18} \mathrm{O}$ values. The $\delta^{13} \mathrm{C}$ signal shows a similar pattern, with the thermocline dwellers showing less variation than the surface dwellers. Results are compared to the empirical model of Kroon and Ganssen (1989) that describes a faunal succession of planktonic foraminiferal species based on isotopic composition and timing of optimum growth conditions. The succession of species based on fluxes was inconclusive and although three of the species showed the same isotopic patterns as described in the model, G. bulloides was not enriched in ${ }^{13} \mathrm{C}$, as predicted. The covariance of $\delta^{13} \mathrm{C}$ and $\delta^{18} \mathrm{O}$ in this particular species suggests that $G$. bulloides is isotopically unreliable for reconstruction of monsoon-induced upwelling in the Arabian Sea.
\end{abstract}

Thesis Supervisor: Dr. William B. Curry

Title: Senior Scientist, Geology and Geophysics Department Chair 


\section{ACKNOWLEDGEMENTS}

I would first like to thank my advisor, Bill Curry, for his extended support and unending patience, despite his busy schedule and duties as Department Chair. I have learned more from him than what is reflected in this thesis.

I would also like to thank M.V.S. Guptha at the National Institute of Oceanography in Goa, India and Venu Ittekkot at the University of Hamburg, Germany for carrying out the sampling program and for access to the sediment trap samples. WHOI Summer Fellow (1993) Kerry Mammone is responsible for the shape analysis on N. dutertrei samples, which was a valuable contribution.

Laboratory assistance came from a number of people. Rindy Ostermann helped me with the mass spectrometer isotopic analyses, taught me tricks of bug-picking, and provided useful scientific comments on my writing. Dick Norris taught me how to use the digitizing equipment necessary for the shape analysis. His genuine excitement about science and the scientific discussions we had are appreciated.

Computer assistance from consultants at MIT and the CIS group at WHOI helped me through a number of computer problems, from Mac to MATLAB to finding a computer to work on. Thanks go to Roger Goldsmith for the programs he wrote to sort the hydrographic data.

I would also like to thank Charlie Langmuir of Lamont-Doherty Earth Observatory for encouraging me, while I was a summer intern, to pursue graduate studies. He noticed a "spark" and gave me the opportunity of a lifetime with the FAZAR cruise. I am most grateful for his belief in my ability and enthusiasm ("Dona Nobis Pacem"). Thanks also to Jen Monteith for being my long-distance cheerleader.

Support from people at WHOI has also helped me immeasurably. Dan McCorkle's quiet understanding, encouragement, advice and discussion helped at times when I needed direction with any of my projects or in general. Julia Westwater and Jake Peirson in the Education office deserve much credit for making my Joint Program days easier and enjoyable. I thank Garrett Ito for late-night camaraderie in Clark and for his optimism: "Get psyched, D!"; Bill Shaw for MATLAB help; Gorka, Ishi, and Tachikara for helping me through the rough times; and Susan Alderman for leading the way.

Special thanks go to those who have dealt with my ups and downs on a day to day basis, especially my housemates for the past three years, Lihini Aluwihare and Kirsten Laarkamp. I thank Sheri White for providing me with a sympathetic ear, a shoulder to cry on, help with GMT, and chalupas!! I thank Lisa DiPalma for her sincere friendship, warm smile, generous use of her computer, and for adding Color to my Bland world.

To everyone who was there for me on 23 August 1995: "Carpé Diem!"

Extra special thanks go to my parents, sisters, and Graeme for always being there to listen, understand and encourage me to follow my dreams. I dedicate this thesis to them, and in memory of Grandpa Jack-- "Something worth doing is worth doing well."

This research was made possible through funding from two sources, the Office of Naval Research (grant \#N00014-93-1-0709) and the National Science Foundation (grant \#OCE-9311396). 


\section{TABLE OF CONTENTS}

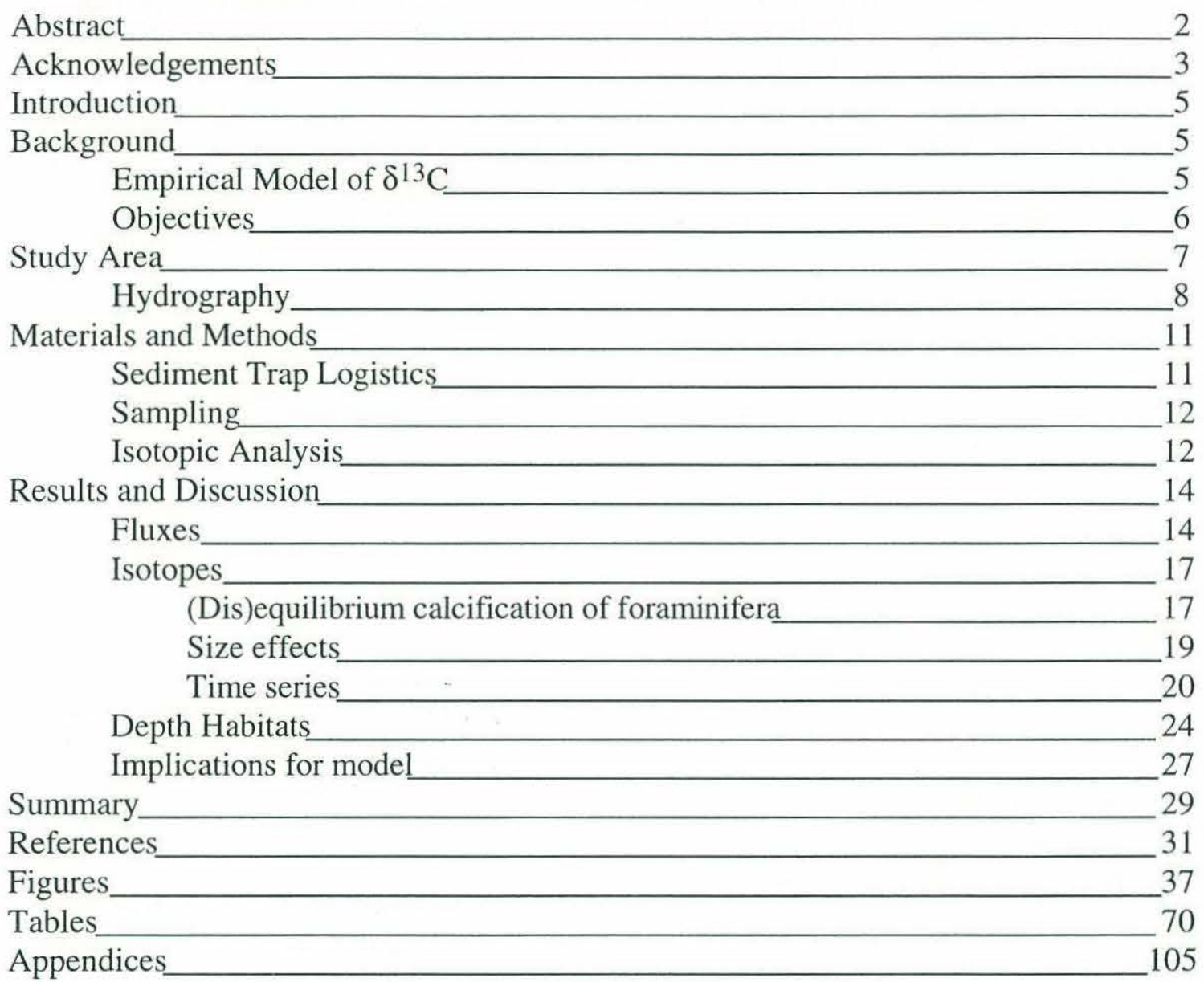




\section{INTRODUCTION}

Foraminifera are marine protozoans with calcareous shells that form a large part of the biomass in many marine ecosystems. They provide information on topics ranging from foraminiferal ecology to larger scale problems like climate cycles. Interannual, centennial, and millennial timescale variability of climate systems is reflected in the flux patterns and isotopic composition of planktonic foraminifera, which makes these microfossils useful when investigating a dynamic area such as the Arabian Sea. Seasonal changes in wind strength and direction, rainfall, productivity and particle fluxes are associated with the monsoon system, and the chemistry of foraminiferal shells may provide a mechanism to reconstruct the past physical and chemical gradients in the water column, as well as constrain the variability of the monsoon-driven productivity and carbon flux. Much of our knowledge of the long-term variability of the southwest monsoon system in the Arabian Sea and its associated upwelling originates from work on core-top and down-core sediment samples [PRELL, 1984; ClEMENS ET AL, 1991; ANDERSON AND PRELL, 1992]. These studies show that monsoon-driven upwelling exhibits significant millennial and orbital scale variability. However, it is still unclear how well foraminiferal chemistry reflects monsoon variability. Time-series sediment trap data is examined in detail in the current study to address the possibility of using foraminifera for reconstruction of shorter timescales, such as the seasonal monsoon cycle.

\section{BACKGROUND}

EMPIRICAL MODEL OF $\delta^{13} \mathrm{C}$

The $\delta^{13} \mathrm{C}$ and $\delta^{18} \mathrm{O}$ of the water column in the Arabian Sea vary due to upwelling, but the extent to which the foraminifera accurately record the water column conditions depends on whether the species calcifies in equilibrium. If foraminifera accurately record the seawater signal while growing in the surface water, then the lightest $\delta^{18} \mathrm{O}$ values should be associated with the heaviest $\delta^{13} \mathrm{C}$ values because preferential uptake of ${ }^{12} \mathrm{C}$ by 
organisms during photosynthesis leaves the surface water enriched in the heavier carbon isotope.

Based on measurements of the carbon isotopic composition of seven species of foraminifera from plankton tows in the northern Indian Ocean, Kroon and Ganssen (1989)

proposed an empirical model relating the $\delta^{13} \mathrm{C}$ signal in foraminiferal tests to the upwelling system. Having observed several species responding to upwelling with opposite $\delta^{13} \mathrm{C}$ changes, they attributed the isotopic differences to temporal differences in the production of the species. Their hypothesis is that the $\delta^{13} \mathrm{C}$ signal of the foraminifera depends on the timing of each species' ideal growing conditions, resulting in a "faunal succession" of species related to the differing phases of the upwelling system. Non-spinose, thermocline dwellers $N$. dutertrei and G. menardii thrive at the incipient stages of upwelling, calcifying in waters that are high in ${ }^{12} \mathrm{C}$ due to the influx of nutrient-rich water from depth. Spinose, shallower dwelling species like $G$. sacculifer and $G$. bulloides flourish in a later stage of upwelling. The heavier $\delta^{13} \mathrm{C}$ values in these species reflect growth in water where the preferential uptake of light carbon into organic matter has balanced or exceeded the amount of ${ }^{12} \mathrm{C}$ carried into the surface waters by upwelling.

\section{OBJECTIVES}

The objectives of this project are to decipher the factors controlling the isotopic signals of four planktonic foraminifera species from a sediment trap deployed in the western Arabian Sea. Two thermocline dwellers (Globorotalia menardii and Neogloboquadrina dutertrei) and two surface dwellers (Globigerinoides sacculifer and Globigerina bulloides) were analyzed for shape and isotopic composition to determine the utility of each species as a tracer of monsoon-related variations. We can test the hypothesis that $\delta^{13} \mathrm{C}$ of various foraminifer species reflects the distinct phases in the upwelling cycle (KROON AND GANSSEN, 1989) by examining the isotopic composition and fluxes of these planktonic foraminifera. The different $\delta^{13} \mathrm{C}$ response should be confirmed by 
corresponding $\delta^{18} \mathrm{O}$ signals, since the ${ }^{18} \mathrm{O} /{ }^{16} \mathrm{O}$ ratios in the shells depend on temperature, and the effect of upwelling is to decrease sea surface temperatures by approximately $4^{\circ} \mathrm{C}$.

The morphometric and isotopic analyses of sediment trap samples provide timeseries information essential to our understanding of how large scale seasonal water column changes associated with monsoon-induced upwelling affect the depth habitat and calcification of foraminiferal species. The Kroon and Ganssen model, based on spatial distribution, will be tested using the temporal distribution of the four species as seen in the sediment trap samples. We will also demonstrate that the fluxes, especially of $G$. bulloides, are good indicators of upwelling but the isotopic signals are complicated by vital effects. This study, along with future time-series sediment trap studies, will aid in the reconstruction of past upwelling in the Arabian Sea, and more generally, will provide clues for the interpretation of the sedimentary record.

\section{STUDY AREA}

The Western Arabian Sea Sediment Trap (WAST) has a time-series collection of planktonic foraminifera that lived before, during, and after upwelling events that occurred during 1986 and 1987 . The trap mooring was located beneath an upwelling cell at $16^{\circ} 19^{\prime} \mathrm{N}$ latitude and $60^{\circ} 28^{\prime}$ E longitude (Figure 1), and thus shows higher foraminiferal fluxes than traps in the Central and Eastern Arabian Sea, mainly because of increased productivity due to higher food availability. Higher production at the WAST location is reflected in elevated chlorophyll concentrations [BROCK ET AL., 1991; BROCK AND MCCLAIN, 1992] and in higher overall fluxes of biogenic opal, carbonate, and organic carbon during the southwest (SW) monsoon.

The study area differs from other upwelling regions in a number of ways. First, windspeeds are highest in the western Arabian Sea because it is a region of maximum wind stress for the southwest monsoon [HASTENRATH AND LAMB, 1979]. Second, unlike other upwelling regions, the western Arabian Sea is not downstream of an eastern 
boundary current so the possibility of colder water and foraminifera being advected into the area is greatly reduced. Each year, at the onset of the southwest monsoon (usually the first week of June), the sea surface temperature drops by $3-6^{\circ} \mathrm{C}$, indicating the sudden influx of cold upwelled subsurface waters.

\section{HYDROGRAPHY}

The Arabian Sea is a region marked by seasonal changes in windspeed and direction. Differential heating of the land and the ocean in the winter and the summer creates gradients which drive the winds. In the northern hemisphere winter, the air over southern Asia is cooler and denser than air over the ocean. The resulting pressure gradient leads to a northeasterly flow of air from Asia to south of the equator, termed the Northeast monsoon. During summer, increased heating of the continent causes a reversal of air flow due to the formation of a low pressure system over southern Asia. Southwesterly winds develop parallel to the coastlines of Somalia and Oman as air moves in to replace the cell of rising air over the land. As the winds of the Southwest monsoon blow over the water, energy is transferred to the surface layers of the ocean. The surface current is deflected offshore, setting up the upwelling system.

Upwelling systems are characterized by the rising of cold, dense subsurface seawater toward the surface to replace water that has been transported offshore by winds or currents. The mixed layer cools and deepens due to wind-induced mixing as the surface waters become colder and more nutrient-rich. The carbon isotopic composition of the water is affected by the mixing of subsurface and surface waters, and by increased primary productivity due to nutrient injection into the euphotic zone during episodes of deep mixing [NAIR ET AL., 1989]. During photosynthesis, light carbon $\left({ }^{12} \mathrm{C}\right)$ in surface waters is preferentially fixed into organic matter by phytoplankton [WONG AND SACKETT, 1987] and then settles to depth. Breakdown of organic matter through oxidation releases the fixed ${ }^{12} \mathrm{C}$ into the deep water, giving these waters an isotopically lighter signature (more negative 
$\delta^{13} \mathrm{C}$ values) than surface waters. According to data from GEOSECS stations in the Arabian Sea, the $\delta^{13} \mathrm{C}$ of the $\Sigma \mathrm{CO}_{2}$ at the surface is $1.6 \%$ (PDB) compared to a value of $0 \%$ (PDB) at a depth of 100-200 meters. When this nutrient-rich subsurface water is upwelled, the local effect is a lowering of surface water $\delta^{13} \mathrm{C}$ which persists until the nutrients are utilized by phytoplankton for photosynthesis. Once essential nutrients are used up, the $\delta^{13} \mathrm{C}$ of the surface water increases to its nutrient-limited value, altered only to a small extent by air-sea exchange.

The sea surface temperatures in the western Arabian Sea for the time of trap deployment (May 1986-October 1987) are plotted in Figure 2. At the onset of upwelling, there is a sudden drop in SST by $\sim 4^{\circ} \mathrm{C}$. Comparison with multi-year sea surface temperature records and ten year averages [SCHWEITZER, 1993], indicates that the 1987 monsoon season had unusually warm sea surface temperatures, about $2-3^{\circ} \mathrm{C}$ higher than normal over the long term. A similar result is seen when comparing the AVHRR satellite data to the historical Levitus monthly means ${ }^{1}$. While both 1986 and 1987 monsoon seasons are warmer than the Levitus monthly means, the 1987 monsoon season temperatures are significantly higher than the averages. Because the range of SSTs is greater, one may also wonder if the 1987 monsoon was stronger than normal. Windspeed measurements by Haake et al. (1993) indicate no difference in windspeeds for 1986 and 1987, implying little difference in monsoon strength. In both years, the duration of increased windspeed is similar, as is the maximum windspeed of $\sim 35$ knots, so the 1987 monsoon year appears to be anomalous only in temperature.

Seasonal temperature changes may be recorded in the $\mathrm{CaCO}_{3}$ test of foraminifera, but in order to determine if the organisms are recording the water column conditions, a common scale must be used for the comparison. Paleotemperature equations provide a

\footnotetext{
${ }^{1}$ Levitus monthly means were obtained from the World Ocean Atlas 1994 (WOA94). See Appendix A for more details.
} 
way to convert the sea surface temperatures to an isotopic scale by calculating the equilibrium oxygen isotopic $\left(\delta^{18} \mathrm{O}_{\mathrm{c}}\right)$ values for each SST.

Early paleotemperature work [EPSTEIN ET AL, 1953; EMILIANI, 1955; O'NEIL ET AL., 1969; SHACKLETON ET AL., 1973] used mollusc shell carbonate, inorganically precipitated calcite, and foraminiferal calcite to determine the relationship between $\delta_{\mathrm{W}}$, the oxygen isotopic composition of the seawater in which the calcite precipitated, and $\delta_{\mathrm{c}}$, the oxygen isotopic composition of calcite precipitated in equilibrium with the water. The paleotemperature equation used in this study is the Shackleton (1973) reformulation of the O’Neil (1969) equation:

$$
\mathrm{T}\left({ }^{\circ} \mathrm{C}\right)=16.9-4.38\left(\delta_{\mathrm{C}}-\delta_{\mathrm{W}}\right)+0.10\left(\delta_{\mathrm{C}}-\delta_{\mathrm{w}}\right)^{2}
$$

where $\delta_{\mathrm{W}}$ is determined from a salinity: $\delta^{18} \mathrm{O}_{\mathrm{w}}$ relationship and temperature is the AVHRR sea surface temperature.

A salinity: $\delta^{18} \mathrm{O}_{\mathrm{w}}$ relationship for the Arabian Sea was determined by linear regression of salinity and $\delta_{\mathrm{w}}$ for shallow $(<200 \mathrm{~m})$ Indian Ocean waters using data from GEOSECS stations (Table 1). The regression is plotted in Figure 3, with the equation of the best fit line relative to SMOW:

$$
\delta^{18} \mathrm{O}_{\mathrm{W}}(\mathrm{SMOW})=0.20(\mathrm{~S} \% \text { o })-6.59
$$

Using a mean salinity of 36.1608\% [LEVITUS ET AL., 1994], the above relationship was used to calculate $\delta^{18} \mathrm{O}_{\mathrm{w}}$ values for the western Arabian Sea. However, to relate water values and calcite values, a conversion [HUT, 1987] from the SMOW2 to $\mathrm{PDB}^{3}$ scales was necessary:

$$
\delta^{18} \mathrm{O}_{\mathrm{w}}(\mathrm{PDB})=\delta^{18} \mathrm{O}_{\mathrm{w}}(\mathrm{SMOW})-0.27
$$

The calculated $\delta^{18} \mathrm{O}_{\mathrm{w}}$ (PDB) values were then used in the paleotemperature equation to find $\delta^{18} \mathrm{O}_{\mathrm{c}}$ values, presented in reference to the PDB scale.

Oxygen isotopic compositions of foraminifera are affected by both temperature and salinity, but due to small seasonal variations in the area around the western Arabian Sea

2 SMOW $=$ Standard Mean Ocean Water

$3 \mathrm{PDB}=$ Pee Dee Belemnite 
sediment trap and the low slope of $\delta^{18} \mathrm{O}_{\mathrm{w}}$ vs. salinity (\%o), the effect of salinity is negligible. Figure 4 shows profiles of $\delta^{18} \mathrm{O}_{\mathrm{c}}$, temperature, $\delta_{\mathrm{w}}$ and salinity from GEOSECS Station 413, which is closest to the sampling area. The $\delta^{18} \mathrm{O}_{\mathrm{c}}$ and temperature profiles are nearly identical, while the salinity variations with depth do not appear to be affecting the $\delta^{18} \mathrm{O}_{\mathrm{c}}$ signal. Thus, temperature variations will control the variations in $\delta^{18} \mathrm{O}$ observed in the foraminifera. Upwelling-related changes in $\mathrm{T}, \mathrm{S}$, and $\delta^{18} \mathrm{O}_{\mathrm{c}}$ are seen in the contoured plots of Figure 5. The rising of subsurface water is reflected in the upward bending of the isotherms, shoaling of the thermocline, and accompanying equilibrium calcite $\delta^{18} \mathrm{O}_{\mathrm{c}}$ values becoming more positive. The greatest effects of upwelling on $\delta^{18} \mathrm{O}$ occur in the upper 100 meters of the water column.

\section{MATERIALS AND METHODS}

SEDIMENT TRAP LOGISTICS

Samples were obtained from a sediment trap mooring in the western Arabian Sea deployed as part of a large, cooperative research program between the University of Hamburg, the National Institute of Oceanography in India, and the Woods Hole Oceanographic Institution. The mooring had two PARFLUX ${ }^{4}$ Mark VI time series sediment traps [HONJO AND DOUGHERTY, 1988], one located 1000 meters below the water surface and the deeper trap located 1000 meters from the ocean floor. Each of the traps was programmed to recover samples every twelve to thirteen days for a six month period. The microprocessor control of the sample cups records the date and time of each sample cup change, providing accurate information about the duration of each sampling interval. Recovery and redeployment of the traps twice during the field program allowed for an eighteen month sampling period which produced a unique set of sediment trap foraminiferal data covering two southwest monsoon seasons and one northeast monsoon season.

${ }^{4}$ PARFLUX $=$ Particulate Flux Experiment 
SAMPLING

Sample analysis and processing of foraminifera after collection from the sediment traps is described in detail by Curry et al. (1992). The foraminifera were sorted by size fraction and species, then counted to determine the flux of each species. The fluxes (\#/m²/day) from the Arabian Sea sediment traps were calculated from the counts, the splits, the known aperture of the sediment trap and the duration of the sample. Four species, two thermocline dwellers (Neogloboquadrina dutertrei, Globorotalia menardii) and two surface dwellers (Globigerinoides sacculifer, Globigerina bulloides) were analyzed for shape and isotopic composition (Tables 2-5). The mass of individual foraminifers was determined using a Mettler MT5 electronic analytical microbalance. Each foraminifer was then affixed to a slide using glue that does not affect the isotopic composition.

The area and maximum length of each individual was digitized using a Stemi SV6 microscope and Sony screen monitor. Once a magnification and configuration have been set, the Optimas 4.0 digitizing program calculates the area of each pixel for the digitized image. To find the area of the outlined shape, Optimas counts the number of pixels and multiplies by the pixel size. Maximum length is found by iteration, where the program finds the largest distance between points and as it traverses around the shape, makes corrections if needed. The maximum length for the Globorotalid species, G. menardii, was found two ways--once laid flat with aperture down in broad view and then balanced on the edge with the aperture up. Restricting the range of shell mass and morphotype was done to reduce any variations in isotopic measurements due to morphotype variability of the foraminifera.

\section{ISOTOPIC ANALYSIS}

Stable isotopes were measured on a Finnigan MAT252 mass spectrometer equipped with a Kiel automated carbonate preparation device. Individual tests of G. sacculifer, $N$. dutertrei, and G. menardii were reacted with $70^{\circ} \mathrm{C}, 100 \% \mathrm{H}_{3} \mathrm{PO}_{4}$ to produce $\mathrm{CO}_{2}$ which 
was then measured for carbon and oxygen isotopic composition. The isotopic results for carbon and oxygen are reported in standard delta notation:

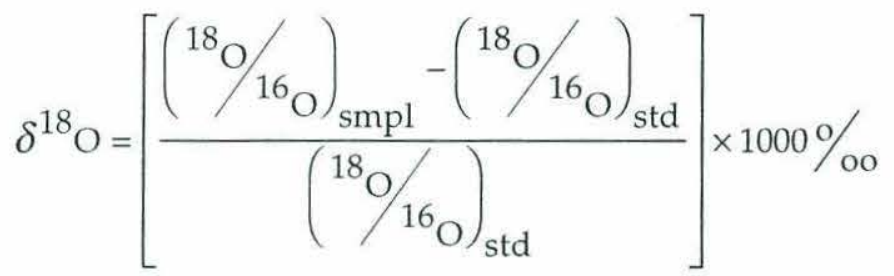

where $\left({ }^{18} \mathrm{O} / 16 \mathrm{O}\right)_{\mathrm{Smpl}}$ is the isotopic ratio in the foraminifera sample, and $\left({ }^{18} \mathrm{O} /{ }^{16} \mathrm{O}\right)_{\mathrm{std}}$ is the isotopic ratio of the standard. The three working standards used were B1 (belemnite), NBS-19 (National Bureau of Standards-19), and our own AtlantisII (deep sea coral). Calibrations to PDB are made through NBS-19 using its known $\delta^{13} \mathrm{C}(1.95 \% 0)$ and $\delta^{18} \mathrm{O}$ $(-2.20 \%$ o) values with respect to PDB.

Individual foraminifers were run as single samples on the mass spectrometer except in cases where the mass was less than or equal to $10 \mu \mathrm{g}$. This lower bound for mass was determined by doing a number of standard tests in which standards ranging from $5 \mu \mathrm{g}$ to $45 \mu \mathrm{g}$ were analyzed to determine the sensitivity of the mass spectrometer and confidence limit for small masses/weights. In cases where a species (G. bulloides, G. sacculifer) had individuals that were too small to be measured alone, two or three foraminifera having similar mass/area ratios were grouped together (Tables 2-5). Foraminifera having the same areas often have different masses (and vice versa) due to differences in calcite thickness. The mass/area ratios represent a "pseudo-density" measurement and allows the specimens to be classed together based on the most similar characteristics. The foraminifera that were analyzed for isotopic composition were from the larger size fractions $(250-500 \mu \mathrm{m},>500 \mu \mathrm{m})$, however most of the G. bulloides flux is from the smaller $(<250 \mu \mathrm{m})$ size fractions, so the isotopic results for this species are not necessarily representative of the majority of the flux. 
The analytical precision for isotopic measurements is size dependent, varying from $\pm 0.08 \%$ oror $\delta^{13} \mathrm{C}$ and $\pm 0.15 \%$ or for $\delta^{18} \mathrm{O}$ in small size samples (10 to $20 \mu \mathrm{g}$ ), to $0.02 \%$ o for $\delta^{13} \mathrm{C}$ and $\pm 0.06 \%$ or $\delta^{18} \mathrm{O}$ for large size samples $(>70 \mu \mathrm{g}$ ) [CURRY, IN PREP].

\section{RESULTS AND DISCUSSION}

The Kroon and Ganssen (1989) model suggests that there will be a specific succession of foraminiferal taxa during an upwelling event, with the isotope response reflecting the timing of shell calcification within the upwelling phase. In the following sections, I will document that the faunal succession is partially supported by the time-series sediment trap data.

The Kroon and Ganssen model was based only on the spatial distribution of species in a series of plankton tows, so time-series sediment trap data provides a temporal check of the hypothesis. Since foraminiferal shell isotopic composition is affected by climate and ontogenetic factors, each of these was examined in detail. Depth habitats for each species were also determined based on the oxygen isotopic composition. The depth of calcification allows us to see where in the water column the foraminifera are living and to infer whether or not they are calcifying in isotopic equilibrium. The thermocline species appear to follow equilibrium, while the surface dwellers are extremely variable, showing ranges in $\delta^{13} \mathrm{C}$ and $\delta^{18} \mathrm{O}$ that exceed the maximum and minimum values for the deeper dwellers. Although the isotopic response to upwelling is complex and only partially confirms the Kroon and Ganssen model, the flux data partially support the predicted faunal succession.

FLUXES

Planktonic foraminifera collected in the Western Arabian Sea sediment trap during 1986 and 1987 showed distinct changes in productivity, abundance of species, and isotopic shell chemistry. The fluxes for all size fractions are presented as a number per square meter per day (\#/m²/day) in Figure 6. Previous work [CURRY ET AL., 1992; THUNELL 
AND SAUTTER, 1992] has shown that planktonic foraminifera respond rapidly to sudden changes in surface water hydrography, including large increases in the total shell flux. The increased flux of foraminifera related to the southwest monsoon of 1986 last nine weeks, from late June 1986 to the end of August 1986 (Julian Days 176 to 241). The southwest monsoon of 1987 also begins mid-June, but high fluxes continue for a longer period (about four months), with fluxes remaining fairly high until October. The only species to have a greater flux during the northeast monsoon season (winter 1986-1987) is G. sacculifer. Relative to the southwest monsoon peaks, the other species have little to no increase in flux during this time.

The most abundant species during the upwelling event is the colder water species G. bulloides, which shows prominent increases in flux during the southwest monsoon. Its abundance (production rate) increased by three orders of magnitude in the western Arabian Sea [CURRY ET AL., 1992] with fluxes as high as 10,000 individuals per square meter per day. There is a flux peak for this species during the 1986 SW monsoon between Julian Days 202-254, which spans just under two months (21 Jul 86-11 Sep 86). The largest flux is seen as a double-humped peak occurring during the 1987 SW monsoon between Julian Days 554-654, which occurred over a three month period ( 8 Jul 87-16 Oct 87). It should be noted that even though the flux during the NE monsoon is negligible compared to the fluxes during the SW monsoons, the absolute flux numbers for this species during this time are greater than the largest flux peaks during the SW monsoons for the other three species (Table 3). Because of this strong response to upwelling, $G$. bulloides flux is a distinct upwelling indicator.

The next most abundant species is $N$. dutertrei, which has the largest peak during the 1986 SW monsoon, with the maximum flux occurring on Julian Day 215 (which corresponds to the two week period of 3 Aug 86 to 15 Aug 86). The SW monsoon of 1987 shows a lower flux, but a longer duration of increased flux. The maximum flux for this time occurs at Julian Day 579 (beginning of August 1987). 
The flux of the other thermocline dweller, G. menardii, is found primarily in the larger $(>250 \mu \mathrm{m})$ size fractions. Like $N$. dutertrei, the largest flux peak is at Julian Day 215 during the SW monsoon of 1986. The second largest peak occurs at Julian Day 382 (mid-January) during the NE monsoon of the 1986-1987 winter. The next peak occurs at Julian Day 566 (which corresponds to the two week period of 20 July 87 to 1 Aug 87) during the SW monsoon of 1987.

G. sacculifer has highest fluxes during the NE monsoon period with the largest flux being on Julian Day 331, and smaller fluxes occurring during the SW monsoons. For 1986, the maximum peak was on Julian Day 215 and for 1987, the maximum peak was on Julian Day 591.

Previous work suggests that foraminifera species have an optimal bloom time during the upwelling period [THUNELL AND SAUTTER, 1992; KROON AND GANSSEN, 1989]. Thunell and Sautter (1992) were able to assign a pre-upwelling, upwelling, or post-upwelling habitat to each of the species they studied based on the flux data, which had weekly resolution. Unfortunately, the Arabian Sea WAST data is bi-weekly, and thus does not resolve subtle changes in pre-, during, or post-upwelling timing. However, a general approximation of timing can be determined. All four species ( $G$. bulloides, G. sacculifer, G. menardii and N. dutertrei) appear to have simultaneous blooms during the 1986 southwest monsoon. During the northeast monsoon, G. menardii, N. dutertrei, and G. bulloides have small increases first, followed by a large peak for G. sacculifer, then a second peak for both G. bulloides and G. menardii. The SW monsoon of 1987 is different than that of 1986 in that the periods of peak flux (maximum bloom) of different species are slightly separated in time. G. menardii and G. sacculifer show early peaks around 25 June 1987 (Julian Day 541), with $N$. dutertrei showing the first peak during the next sampling interval beginning 20 July 1987 (Julian Day 566). Finally, the G. bulloides peaks in late August (Julian Day 600). The only species to have its peak flux occur during the interval 
between the southwest monsoons is G. sacculifer. The timing of the species' flux peaks is similar to that suggested by the model based on isotopic composition. For this study, the 1987 southwest monsoon flux peaks appear to corroborate the Kroon and Ganssen faunal succession for N. dutertrei, G. menardii and G. bulloides.

\section{ISOTOPES}

When using foraminifera as a tool for decoding climate histories, a good understanding of the factors affecting the incorporation of the chemical signal is prerequisite to making any conclusions about the climate system. One of the factors that could be affecting the isotopic signal is changing calcification conditions throughout the growth stages of the individual foraminifer. In the beginning stages of ontogeny the foraminifer generally calcifies out of equilibrium for $\delta^{13} \mathrm{C}$ and perhaps $\delta^{18} \mathrm{O}$ [EREZ AND LUZ, 1983; BÉ, 1982]. Larger individuals, however, have $\delta^{13} \mathrm{C}$ and $\delta^{18} \mathrm{O}$ values which approach equilibrium. Since planktonic foraminifera continue to calcify throughout their entire life, including the period when they sink through the water column, the isotopic signal in the shells represents an average of the entire calcification process. Thus, it is important to maintain uniformity in both mass and shell size for isotopic analyses in order to better interpret signals in the isotopic composition from multiple effects throughout growth.

\section{(Dis)equilibrium calcification of foraminifera}

There is some disagreement about the ability of foraminifera to adequately record seasonal climate variations because factors affecting the isotopic signal of foraminifera are poorly understood [BERGER ET AL., 1978; PRELL AND CURRY, 1981; KROON AND GANSSEN, 1989; CURRY ET AL., 1992]. Skeletal carbonate originates from two different sources--sea water bicarbonate $\left(\mathrm{HCO}_{3}^{-}\right)$that is incorporated into the skeleton by isotopic equilibrium processes, and an internal metabolic $\mathrm{CO}_{2}$ pool which is known to be depleted 
in the heavy isotopes of carbon and oxygen [WEBER AND WOODHEAD, 1970]. The extent to which $\mathrm{CO}_{3}{ }^{2-}$ from each of these two sources is taken up by foraminifera determines whether or not the shell calcifies in isotopic equilibrium. If a significant proportion of foraminiferal test carbonate is derived from metabolic $\mathrm{CO}_{2}$ rather than originating solely from seawater bicarbonate, then both the $\delta^{13} \mathrm{C}$ and $\delta^{18} \mathrm{O}$ ratios will be more negative than those of $\mathrm{CaCO}_{3}$ formed in isotopic equilibrium with ambient seawater.

Numerous studies have indicated that carbon isotopic fractionation may result from "vital effects", which depend on the ontogenetic stage of the individual as well as on the depth habitat [BOUVIER-SOUMAGNAC AND DUPLESSY, 1985; VERGNAUD-GRAZZINI, 1976; WILLIAMS ET AL., 1977]. The cause of the fractionation could be related to growth of an individual, food habits, or the activity of symbiotic algae.

The oxygen isotopic composition $\left(\delta^{18} \mathrm{O}\right)$ of foraminifera is closer to equilibrium than $\delta^{13} \mathrm{C}$, although there is evidence for small deviations from equilibrium. MOCNESS 5 tow data show $\delta^{18} \mathrm{O}$ values $0.2 \%$ to $0.3 \%$ lower than equilibrium for $G$. ruber [FAIRBANKS ET AL., 1982] although Curry et al. (1992) found this same species deviated $\sim 0.5 \%$ o from equilibrium. Bouvier-Soumagnac and Duplessy (1985) found the deviation from equilibrium for $N$. dutertrei, G. menardii, and $O$. universa to be $0.2 \%$ to $0.3 \%$.

The oxygen isotopic composition of foraminifera is further complicated by gametogenesis [EREZ AND HONJO, 1981; DUPLESSY ET AL., 1981]. Gametogenesis is a process that involves the formation of gametes and represents only a small fraction of time in the total foraminifera lifecycle. However, this process is accompanied by secondary calcification, which forms a heavier crust that may be as much as $20 \%$ of the total shell weight [BÉ, 1980], and can contribute largely to the isotopic signal [EREZ AND HONJO, 1981; DUPLESSY ET AL., 1981]. By examining size, shape, and isotopic composition of individual foraminifera, it is possible to constrain the effect of gametogenic calcification in the isotopic signal.

${ }^{5}$ MOCNESS $=$ Multiple Opening and Closing Sampler Nets and Environmental Sampling System 
The isotopic composition may also be an indicator of depth habitat for foraminifera species. There is strong agreement between relative isotopic depth rankings of planktonic foraminifera and depth rankings from plankton tow observations [EMILIANI, 1954; BERGER, 1969; WILLIAMS, 1976] suggesting that foraminiferal shell $\delta^{18} \mathrm{O}$ values are generally close to equilibrium. There is also agreement between isotopic temperatures calculated from observed $\delta^{18} \mathrm{O}$ values of shallow-dwelling foraminifera in core top samples and observed sea surface temperatures [EMILIANI, 1966; SAVIN AND DOUGLAS, 1973; WilliamS, 1976; WiLliamS AND HEALY-WiLliamS, 1980; CURRY AND MATTHEWS, 1981]. If the foraminifera calcify out of oxygen isotopic equilibrium, they appear to do so with a constant offset that is characteristic for a certain species. This is important for the interpretation of paleoceanographic isotope studies because a basic assumption of this type of study is that the oxygen isotopic composition of the foraminiferal test accurately reflects the temperature and oxygen isotopic composition of the seawater in which it grew.

\section{$\underline{\text { Size Effects }}$}

There is a general trend of heavier $\delta^{13} \mathrm{C}$ with larger mass in all four species of foraminifera studied, with $G$. sacculifer and $N$. dutertrei showing stronger positive correlations than the other two species (Figure 7). Similar results are seen when $\delta^{13} \mathrm{C}$ values are plotted with the quantities of maximum length and area. The relationships of $\delta^{13} \mathrm{C}$ to all three measurements of size for the foraminifera indicate that the larger the individual, the more positive is the $\delta^{13} \mathrm{C}$ value. One explanation for this trend is that smaller foraminifera (probably juveniles) incorporate larger amounts of metabolic $\mathrm{CO}_{2}$ into their tests, resulting in more negative $\delta^{13} \mathrm{C}$ values.

This carbon isotopic trend with size has previously been observed in a number of studies. Bouvier-Soumagnac and Duplessy (1985) observed that both G. menardii and N. dutertrei begin to grow their shells close to the surface, but continue to add chambers to the shell and increase their weight below the mixed layer. The larger specimens of these two 
species showed enrichment in ${ }^{13} \mathrm{C}$, but no significant differences in $\delta^{18} \mathrm{O}$. This agrees with the observations of Fairbanks and others $(1980,1982)$ on living samples from the western North Atlantic and the Panama Basin. However, Kahn (1979) reported large $\delta^{18} \mathrm{O}$ differences in shell size in samples from the equatorial Atlantic. Similarly, Williams et al. (1981) found that isotopic composition is highly dependent on shell size with larger individuals being enriched in $\delta^{13} \mathrm{C}$ and $\delta^{18} \mathrm{O}$.

Oxygen isotopic composition shows variations with size as well, although the sediment trap samples show a trend opposite that suggested by Williams et al. (1981) and core top results [PRELL AND CURRY, 1981]. Western Arabian Sea sediment trap $G$. menardii $\delta^{18} \mathrm{O}$ values fall within a constant band of $\delta^{18} \mathrm{O}(-1.5 \%$ to $0 \%$ ) regardless of the size of the individual, which is what Bouvier-Soumagnac and Duplessy (1985) saw in $G$. menardii and $N$. dutertrei samples. WAST $N$. dutertrei and G. sacculifer show a "reverse trend" of decreasing $\delta^{18} \mathrm{O}$ with increasing size (Figure 8), similar to that observed in prior investigations [DUNBAR, 1983; WEFER ET AL., 1983; SAUTTER AND THUNELL, 1991]. This negative correlation of $\delta^{18} \mathrm{O}$ and size implies that if the foraminifera were calcifying in equilibrium, then the larger individuals were living higher in the water column, where warmer water results in more negative $\delta^{18} \mathrm{O}$ values.

\section{Time series}

The time series of oxygen isotopic composition for each species is plotted in

Figures 9-12 with a band of equilibrium calcite sea surface temperature values superimposed. The band of $\delta^{18} \mathrm{O}_{\mathrm{c}}$ represents the range of calculated values for surface water temperatures using bounds of \pm 2 standard deviations of the mean annual salinity. Since the salinity has a minimal effect on $\delta^{18} \mathrm{O}_{\mathrm{c}}$ in this area, the variability is small. Comparison of these equilibrium calcite SST values to the foraminiferal stable isotopic data indicates whether the foraminifera are calcifying in isotopic equilibrium with the surface waters, and whether they record the seasonality of the monsoons. 
The data is shown with no lag and with a 21 day lag to include the minimum and maximum settling rates, as well as the duration of the foraminiferal lifecycle $(<30$ days). The lag time accounts for varying settling rates of the foraminifera, and was determined from experimental data [CURRY, UNPUBLISHED DATA]. Using the minimum and maximum values for length and mass of the Arabian Sea foraminifera species, the minimum and maximum sinking speeds were determined from sinking speed vs. length or sinking speed vs. weight relationships from the Panama Basin experimental data. There are no sinking speed data for $G$. bulloides, but the other three species' minimum sinking speed, with respect to both length and mass, was 700 meters/day. The maximum was 2500 meters/day. If the foraminifera sank at a rate of 700 meters/day, they would reach the shallow trap ( 1000 meters) in approximately a day and a half, and reach the deep trap ( $\sim 3000$ meters $)$ in a little over four days. However, these experimental rates may be overestimates of sinking speed if biological factors are taken into account. Considering the foraminifer lifecycle, differing densities between living foraminifera with protoplasm and empty shells, and drag in the water column due to spines, I chose three weeks (from death to collection in the sediment trap) as a conservative estimate of the lag for the samples.

The $\delta^{18} \mathrm{O}$ values for $N$. dutertrei and $G$. menardii remain fairly constant throughout the time series, with only a slight decrease accompanying the warmer sea surface temperatures during the 1987 monsoon season (Figures 9, 10). G. menardii values range from $-2 \%$ to $0 \%$, while $N$. dutertrei values range from -1.5 and $-0.5 \%$ (Figure 13). This range in $\delta^{18} \mathrm{O}$ indicates a stable environment, and supports the idea that $G$. menardii and $N$. dutertrei are deep dwellers, calcifying subsurface and showing little effect from sea surface temperature variation. All of the isotopic values for G. menardii and $N$. dutertrei fall within the range of possible equilibrium values when a 21 day lag is applied.

The spinose shallow dwellers show a much wider range in values, seemingly reflecting the shifting conditions near the surface (Figures 11, 12). Excluding five 
measurements occurring around Julian Day $215^{6}$, all the G. sacculifer $\delta^{18} \mathrm{O}$ values are very light, ranging from $-1 \%$ to $-3 \%$, with almost half of the individuals having $\delta^{18} \mathrm{O}$ values lower than the lowest surface water equilibrium. Lagging the results by 21 days brings more values into equilibrium, primarily those for the $1986 \mathrm{SW}$ monsoon and the NE monsoon. However the 1987 SW monsoon values are significantly lower than equilibrium surface water values. In a pulsating upwelling cell, the conditions change rapidly, which may partially explain the wide range and the disequilibrium, that is also seen in $G$. bulloides. This species has the largest range of $\delta^{18} \mathrm{O}(-4 \%$ to $+2 \%$ ) with some values extending past the range of the deep dwellers (Figures 13-15).

A basic assumption in paleoceanographic isotope studies is that the isotopic composition of the foraminiferal test calcite accurately reflects the temperature and nutrient concentrations of the ambient water column. During monsoons, cold nutrient-rich subsurface water is upwelled, leaving the surface water enriched in $\delta^{18} \mathrm{O}$ and depleted in $\delta^{13} \mathrm{C}$. If foraminifera are calcifying in equilibrium, they will reflect this water column isotopic signal. Figures $\mathbf{1 6}$ and $\mathbf{1 7}$ show the carbon and oxygen isotopic averages plotted with equilibrium sea surface temperatures. G. menardii has a range of $\sim 0.7 \%$ o $\delta^{18} \mathrm{O}$, and a range of $\sim 1 \% \circ \delta^{13} \mathrm{C}$. During the monsoons, there is an increase in $\delta^{18} \mathrm{O}$ by $0.5 \%$ and a decrease in $\delta^{13} \mathrm{C}$ by $0.5 \%$. $N$. dutertrei has a range of $\sim 0.7 \%$ in $\delta^{18} \mathrm{O}$ and $\sim 1.75$ range in $\delta^{13} \mathrm{C}$. During the monsoons, there is an increase in $\delta^{18} \mathrm{O}$ by $\sim 0.5 \%$ and a decrease in $\delta^{13} \mathrm{C}$ by $\sim 1 \%$. The range of G. sacculifer is about $2 \%$ for $\delta^{18} \mathrm{O}$ and $1 \%$ for $\delta^{13} \mathrm{C}$. During the monsoons, $\delta^{18} \mathrm{O}$ increases by $1.2 \%$ for $1986 \mathrm{SW}$ monsoon, $\sim 1.0 \%$ for NE monsoon, and $\sim 0.5 \%$ for the $1987 \mathrm{SW}$ monsoon. The $\delta^{13} \mathrm{C}$ of this same species decreases by one per mil during all monsoons. G. bulloides has a $1.75 \%$ range in $\delta^{18} \mathrm{O}$ and a $1.5 \%$ range in $\delta^{13} \mathrm{C}$. The data show that thermocline dwellers' $\delta^{18} \mathrm{O}$ increases a little less than $1 \%$, while the surface dwellers exhibit larger amplitude $\delta^{18} \mathrm{O}$ changes of

${ }^{6}$ The values for these five measurements have been verified. They are correct measurements, not due to erroneous data. However, the reason for the deviation from the average is unknown. 
$2 \%$. In times of upwelling, especially during the southwest monsoons, G. menardii, N. dutertrei and G. sacculifer have opposite isotopic signals as expected: the $\delta^{18} \mathrm{O}$ increases at the same time $\delta^{13} \mathrm{C}$ decreases. However, G. bulloides $\delta^{13} \mathrm{C}$ and $\delta^{18} \mathrm{O}$ covary, with both increasing during the upwelling periods. Strong positive correlations between $\delta^{18} \mathrm{O}$ and $\delta^{13} \mathrm{C}$ suggest disequilibrium calcification with respect to oxygen, and/or carbon [CURRY AND MATTHEWS, 1981] because the lightest $\delta^{18} \mathrm{O}$ values (i.e. warm surface water) should be associated with the heaviest values of $\delta^{13} \mathrm{C}$.

Another way to see if the foraminifera are calcifying in equilibrium with the surface water is to compare their isotopic values with the water column values. Since there is no real-time CTD or other hydrographic data, the GEOSECS Stations 413 and 417 water column $\delta^{18} \mathrm{O}$ and $\delta^{13} \mathrm{C}$ are used. The most striking aspect of Figure 18 is that for $G$. bulloides, $\delta^{13} \mathrm{C}$ and $\delta^{18} \mathrm{O}$ vary opposite to the water column trend. The range in $\delta^{13} \mathrm{C}$ is nearly twice the water column variability while the other three species (G. menardii, $G$. sacculifer, and $N$. dutertrei) exhibit patterns which parallel the hydrographic profile. These foraminifera are presumably recording the temperature of the ambient water and its range of salinity and temperature, as well as the nutrients. Except for several measurements around $0 \%$ for G. sacculifer, both G. bulloides and G. sacculifer show $\delta^{18} \mathrm{O}$ values lighter than N. dutertrei and G. menardii, in agreement with their reported depth habitats [BÉ, 1960; BÉ AND LOTT, 1964; BÉ AND TOLDERLUND, 1967; BÉ, 1982]. G. sacculifer and $G$. bulloides are thought to live in the mixed layer whereas $N$. dutertrei and G. menardii live deeper near the thermocline.

Previous authors have suggested that $G$. bulloides secretes its calcite test in isotopic disequilibrium with respect to carbon and oxygen [KAHN AND WILLIAMS, 1981; SAUTTER AND THunELl, 1991; ALDERMAN, 1996], while others have indicated that $G$. bulloides calcifies close to oxygen isotopic equilbrium [CURRY AND MATTHEWS, 1981; DUNBAR, 1983; GANSSEN AND SARNTHEIN, 1983] but is in strong disequilibrium with respect to carbon [WilliamS ET AL., 1977; KAHN AND WilLiamS, 1981; DunBAR, 1983]. Most 
recently, Spero and Lea (1996) quantified the environmental and physiological parameters responsible for disequilibrium in cultured $G$. bulloides, finding that $8-15 \%$ of the chamber $\delta^{13} \mathrm{C}$ signal was due to the incorporation of metabolic $\mathrm{CO}_{2}$. If fifteen percent of the $\delta^{13} \mathrm{C}$ signal comes from metabolic $\mathrm{CO}_{2}$ with a $\delta^{13} \mathrm{C}$ value of $-20 \%$ and the other $85 \%$ comes from $\delta^{13} \mathrm{C}$ of $1.5 \%$, then the expected $\delta^{13} \mathrm{C}$ value would be $-1.7 \%$. Thus, incorporation of metabolic $\mathrm{CO}_{2}$ may force errors (as large as $3.0 \%$ ) in the $\delta^{13} \mathrm{C}$ that are greater than or equal to the water column variability from surface to seafloor $(\sim 1.6 \%$ ).

The $\delta^{18} \mathrm{O}$ and $\delta^{13} \mathrm{C}$ ranges for each species are plotted as histograms in Figures 14, 15. The average $\delta^{13} \mathrm{C}$ for $G$. bulloides is about $-1.7 \%$, which corresponds to the work of Spero and Lea (1996) considering metabolic $\mathrm{CO}_{2}$ incorporation. This value is quite different from the $\delta^{13} \mathrm{C}$ averages for the other three species, which have positive ranges from $0.5 \%$ o to $2 \%$. For both $\delta^{18} \mathrm{O}$ and $\delta^{13} \mathrm{C}$, the thermocline dwellers show a narrower range of values, which is consistent with a stable, deeper habitat.

\section{DEPTH HABITATS}

Depth rankings of the foraminifera can be determined based on the average species ranges of oxygen isotopes (Figures 13, 15). Assuming the lightest $\delta^{18} \mathrm{O}$ values represent the shallowest living species, and the heaviest (more positive) $\delta^{18} \mathrm{O}$ values represent the deeper dwellers, the depth ranking (from shallow to deep) is as follows: $G$. bulloides, G. sacculifer, N. dutertrei and G. menardii.

Planktonic foraminifera live mainly in the euphotic zone, where the phytoplankton and zooplankton upon which they feed are found in highest abundance. However, differences in ecological and physiological requirements result in the segregation of foraminifera species by depth [BÉ, 1982]. Species with photosynthetic algal symbionts are limited to the sunlit waters, while the non-symbiotic species can live much deeper in the water column because they have no light requirements, only food requirements. Since $G$. 
sacculifer has symbiotic algae [ANDERSON AND BÉ, 1976], this species is generally found in sunlit surface waters.

Using the World Ocean Atlas (1994) climatology and assuming that the foraminifera calcify in equilibrium, which we have shown is not always true, a depth where calcification occurred for each individual can be estimated. However, since foraminifera calcify at different depths and temperatures throughout their entire lifecycle, the calcite tests record a variety of hydrographic conditions. The isotopic composition represents an average of the entire calcification history [EREZ AND LUZ, 1983], and the assigned depth is a mean of the various depths where the foraminifera calcified.

The depth range calculated for G. menardii and N. dutertrei is between 50 to 150 meters depth, although the foraminifera appear to be following a nearly constant band of $\delta^{18} \mathrm{O}$ rather than remaining at a fixed depth. G. menardii and $N$. dutertrei exhibit very little seasonal change in $\delta^{18} \mathrm{O}$, with values varying mainly during the SW monsoon upwelling period (Figures 19, 21). When a 21 day lag is taken into account, values which had previously appeared to be out of equilibrium come within the realm of equilibrium calcification within the thermocline (Figures 20, 22).

For G. sacculifer and G. bulloides, however, a different pattern emerges (Figures 23, 24). Many of the isotopic values are lower than the lowest possible equilibrium values for surface waters, implying that these taxa must be calcifying out of oxygen isotope equilibrium. This follows the observations of Fairbanks et al. (1980, 1982), in which $\delta^{18} \mathrm{O}$ values obviously lower than equilibrium were seen only in the spinose species. In the western Arabian Sea trap (WAST), the spinose species G. sacculifer and G. bulloides show $\delta^{18} \mathrm{O}$ values which are lower than the lowest $\delta^{18} \mathrm{O}$ values possible for the water column. If a lag is taken into account, more points fall within the possible range of equilibrium values, but there is still obvious disequilibrium. A possible explanation for disequilibrium in G. sacculifer is the presence of its symbiotic algae [HEMLEBEN AND SPINDLER, 1983] which is supported by the isotope vs. mass data which shows a "classic 
photosymbiont trend" [PERS. COMM., DICK NORRIS]. However, G. bulloides does not have symbionts, so there must be another factor affecting its isotopic composition.

The separation of species by depth according to ecological preferences does not always occur, especially in a dynamic region like the Arabian Sea where hydrographic conditions are highly variable. Monsoon-induced upwelling creates a highly mixed water column in which the conditions at the surface are also conducive to the deeper dwelling species, thus allowing the non-spinose thermocline dwellers to live and calcify in the same waters as the spinose surface dwellers.

Steens et al. (1992) suggest that the difference in oxygen isotope values $\left(\Delta \delta^{18} \mathrm{O}\right)$ between a surface dweller ( $G$. bulloides) and a thermocline dweller $(N$. dutertrei) is a measure of upwelling intensity. In the Arabian Sea, shoaling of the thermocline during upwelling may create an environment where deep dwellers can live together with the surface dwellers. For example, when strong upwelling drives $N$. dutertrei nearer to the surface, the two species may live and calcify in the same waters, so the isotopic compositions of their tests are similar and the $\Delta \delta^{18} \mathrm{O}$ becomes smaller. In non-upwelling areas, the species have different depth habitats in a stratified water column, so the $\Delta \delta^{18} \mathrm{O}$ is larger. The $\Delta \delta^{18} \mathrm{O}$ values for surface minus thermocline dwellers for WAST are plotted in Figure 25. As previously shown [STEENS ET AL., 1992], the differences between $\delta^{18} \mathrm{O}$ values for G. bulloides and N. dutertrei are plotted. Comparisons of G. sacculifer, the other surface dweller, to each of the thermocline dwellers are also examined. The $\delta^{18} \mathrm{O}$ differences between $G$. bulloides and $G$. menardii, and between $G$. bulloides and $N$. dutertrei are less during times of upwelling, providing support for the Steens et al. (1992) observations. When comparing G. sacculifer to the deep dwellers, the difference is very small during the $1986 \mathrm{SW}$ monsoon, but greater during the 1987 monsoon. If $\delta^{18} \mathrm{O}$ values are near to equilibrium then the species calcified together under the same conditions in a cooled water column with a deep mixed layer during the 1986 SW monsoon. During the 
1987 SW monsoon, however, G. sacculifer $\delta^{18} \mathrm{O}$ remains around $-2.0 \%$, while the thermocline dwellers and G. bulloides all have values of $-1.0 \%$.

There is a tendency for $\delta^{13} \mathrm{C}$ of $G$. menardii and $N$. dutertrei to decrease by $\sim 1 \%$ o during the upwelling while G. bulloides $\delta^{13} \mathrm{C}$ increases by the same amount (Figure 26). This trend is similar to that observed by Kroon and Ganssen (1989) in their spatial data sets from plankton tows but the range of $\delta^{13} \mathrm{C}$ change observed in the WAST samples is nearly as large as the entire water column gradient. However, because $G$. bulloides $\delta^{18} \mathrm{O}$ approaches the $\delta^{18} \mathrm{O}$ of the thermocline dwellers, its $\delta^{13} \mathrm{C}$ should also become lower if it is being affected by the water column gradient of $\delta^{13} \mathrm{C}$. I have presented data which suggests that disequilibrium processes (as implied by the highly variable, strongly covariant $\delta^{13} \mathrm{C}$ and $\delta^{18} \mathrm{O}$ ) of $G$. bulloides are overwhelming the primary signal of upwelling. It is difficult to imagine a scenario where contemporaneous individuals are varying like this isotopically as a function of the water column hydrography alone. It is unlikely that $G$. bulloides $\delta^{13} \mathrm{C}$ will prove to be a reliable recorder of upwelling. On the other hand, $G$. menardii and $N$. dutertrei show clear decreases in $\delta^{13} \mathrm{C}$ during the upwelling, making their carbon isotopic values a potentially useful upwelling proxy.

\section{IMPLICATIONS FOR THE KROON AND GANSSEN MODEL}

Spinose and non-spinose foraminifera from plankton tows in the Northern Indian Ocean show different isotope responses to upwelling, which Kroon and Ganssen (1989) inferred to be from temporal differences in calcification during successive colder and warmer periods of the upwelling cycle. Instead of attributing the difference in $\delta^{13} \mathrm{C}$ values to varying vital effects within species, they assumed that the isotopic signal was related to the time of the species' optimal living conditions during the pulsating upwelling phases. For example, G. menardii and $N$. dutertrei showed low $\delta^{13} \mathrm{C}$ values, so Kroon and Ganssen predicted that both of these non-spinose species were living and calcifying at the incipient stages of upwelling, when the surface waters were enriched in ${ }^{12} \mathrm{C}$ from the 
upwelled, nutrient-rich subsurface water. G. sacculifer exhibited only a slight change in $\delta^{13} \mathrm{C}$ and $\delta^{18} \mathrm{O}$, indicating growth at a time later in the upwelling phase when the preferential uptake of ${ }^{12} \mathrm{C}$ by organic matter may have balanced the amount brought in by the upwelled water. G. bulloides is different from the three previously mentioned species in that it showed ${ }^{13} \mathrm{C}$ enrichment in the upwelling zone, which suggests that it thrives in the final stage of upwelling when the fixation of ${ }^{12} \mathrm{C}$ by phytoplankton exceeds the amount of ${ }^{12} \mathrm{C}$ brought to the surface waters. Based on the plankton tow data, the faunal succession order predicted by Kroon and Ganssen was G. menardii, N. dutertrei, G. sacculifer, and then G. bulloides.

During a sediment trap study in the San Pedro Basin [THunELl AND SAUTTER, 1992], the timing of each species' bloom was recorded via weekly sampling, giving evidence for faunal succession different from that proposed by Kroon and Ganssen (1989). Instead of thriving at the incipient stages of upwelling, $N$. dutertrei dominated during the post-upwelling period. G. bulloides was found in the later stages of upwelling as predicted, but both $\delta^{13} \mathrm{C}$ and $\delta^{18} \mathrm{O}$ showed decreases of 1 to $2 \%$. The $\delta^{13} \mathrm{C}$ change is consistent with the upwelling of nutrient-rich water, but the $\delta^{18} \mathrm{O}$ change is opposite what is expected if this species was recording the upwelling of colder water. This isotope response for $G$. bulloides in the San Pedro Basin differs from that predicted by Kroon and Ganssen, and it differs from the results of the current sediment trap study from the western Arabian Sea.

The WAST data shows the average $\delta^{13} \mathrm{C}$ values of the thermocline dwellers, $G$. menardii and $N$. dutertrei, decreasing during upwelling and exhibiting $\delta^{13} \mathrm{C}$ lower than $G$. sacculifer, which follows the prediction of the model. However, G. bulloides has the lowest $\delta^{13} \mathrm{C}$ values of all, with average values nearly $2 \%$ olower than the $\delta^{13} \mathrm{C}$ values for the other three species, which is drastically different than expected. According to the model predictions, this species should exhibit high $\delta^{13} \mathrm{C}$ and low $\delta^{18} \mathrm{O}$, but instead the $G$. bulloides from this study show increases in both $\delta^{13} \mathrm{C}$ and $\delta^{18} \mathrm{O}$. This implies that the 
isotopic signal of $G$. bulloides is affected by vital effects which are overwhelming the primary hydrographic signal. The Arabian Sea and San Pedro Basin data both show that G. bulloides does not record the water column conditions expected from upwelling, and may have a large portion of the $\delta^{13} \mathrm{C}$ signal stemming from the incorporation of metabolic $\mathrm{CO}_{2}$ during ontogeny [SPERO AND LEA, 1996].

\section{SUMMARY}

Kroon and Ganssen (1989) suggested that foraminifera species show a faunal succession, based on timing of optimum living conditions, during upwelling with the isotopic compositions reflecting the different phases of the upwelling system rather than a vital effect. This empirical model was based only on spatial distributions from plankton tows but is partially supported by faunal succession observed in the western Arabian Sea sediment trap; the fluxes of three of the four study species during the 1987 southwest monsoon follow the succession suggested by the model. However, the carbon isotopic composition of G. bulloides is opposite to that seen in the plankton tow data, and the variability within this species is nearly twice the water column variability. The other three species (G. menardii, N. dutertrei, and G. sacculifer) follow the water column trend for $\delta^{18} \mathrm{O}$ and $\delta^{13} \mathrm{C}$, and probably provide useful paleoceanographic information on upwelling. The thermocline dwelling species ( $N$. dutertrei and $G$. menardii) have narrow ranges of $\delta^{18} \mathrm{O}$ due to the stability of their deeper habitat, and they appear to be calcifying in

equilibrium. These deeper dwellers also show a decrease in $\delta^{13} \mathrm{C}$ in response to upwelling as predicted by the Kroon and Ganssen (1989) model. The surface or mixed layer species (G. bulloides and G. sacculifer) are more variable, with a significant portion of $\delta^{18} \mathrm{O}$ values lower than the lowest equilibrium values, regardless of the lag time taken into account. Their $\delta^{13} \mathrm{C}$ values show considerable variability as well, with G. bulloides becoming more than $1 \%$ heavier during upwelling. While this pattern $(N$. dutertrei decreasing in $\delta^{13} \mathrm{C}$, G. bulloides increasing in $\delta^{13} \mathrm{C}$ ), is the same as predicted by Kroon 
and Ganssen (1989), the magnitude of the variability is very large--larger than the full range of $\delta^{13} \mathrm{C}$ observed in the water column. Because the $\delta^{13} \mathrm{C}$ and $\delta^{18} \mathrm{O}$ trend within $G$. bulloides covaries positively and is extremely large, we discount its usefulness for upwelling reconstructions. Instead we believe G. bulloides $\delta^{13} \mathrm{C}$ is dominated by vital effects (perhaps growth rate), which may explain the patterns observed in the western Arabian Sea sediment traps as well as the plankton tow samples of Kroon and Ganssen. 


\section{REFERENCES}

Alderman, S.E. 1996. Planktonic Foraminifera in the Sea of Okhotsk: Population and Stable Isotopic Analysis from a Sediment Trap. MIT/WHOI Joint Program for Oceanography and Ocean Engineering, Master's Thesis, 99 pp.

Anderson, D.M. and Prell, W.L. 1991. High resolution record of monsoon upwelling from the proximal upwelling zone, Site 723; In: W.L. Prell and N. Niitsuma (eds) Proc. ODP, Scientific Results 117: Ocean Drilling Program, College Station, TX. p. 365-388.

Anderson, D.M. and Prell, W.L. 1991. Foraminifer abundance in the Arabian Sea upwelling region during the late Pleistocene, In: W.L. Prell and N. Niitsuma (eds) Proc. ODP, Scientific Results 117: Ocean Drilling Program, College Station, TX.

Anderson, D.M. and Prell, W.L. 1992. The structure of the southwest monsoon winds over the Arabian Sea during the later Quaternary: observations, simulations, and marine Geologic evidence. Journal of Geophysical Research, 97: 15,481-15,487.

Anderson, R.O. and Bé, A.W.H. 1976. The ultrastructure of a planktonic foraminifer, Globigerinoides sacculifer (Brady), and its symbiotic dinoflagellates. Journal of Foraminiferal Research, 6: 1-21.

Bé, A.W.H. 1960. Ecology of Recent planktonic foraminifera: Part 2--Bathymetric and seasonal distributions in the Sargasso Sea off Bermuda. Micropaleontology, 6: 373-392.

Bé, A.W.H. 1982. Biology of Planktonic Foraminifera. In: M.A. Buzas and B.K. Sen Gupta, Foraminifera: Notes for a Short Course. University of Tennessee Department of Geological Sciences, prepared for short course on foraminifera sponsored by the Paleontological Society. New Orleans, LA October 17, 1982. edited by T.W. Broadhead

Bé, A.W.H. and Lott, L. 1964. Shell growth and structure of planktonic foraminifera from marine plankton samples. Science, 145: 824-832.

Bé, A.W.H. and Tolderlund, D.S. 1971. Distribution and ecology of living planktonic foraminifera in surface waters of the Atlantic and Indian Oceans. In: B.M. Funnell and W.R. Reidel, (eds), Micropaleontology of Oceans. Cambridge University Press: London, p.105-149.

Berger, W.H. 1969. Ecological patterns of living planktonic foraminifera. Deep Sea Research, 16: 1-24

Berger, W.H.; Killingley, J.S.; and Vincent, E. 1978. Stable isotopes in deep-sea carbonates: boxcore ERDC-92, West Equatorial Pacific. Oceanologica Acta, 1: 203-216.

Bouvier-Soumagnac, Y. and Duplessy, J-C. 1985. Carbon and oxygen isotopic composition of planktic foraminifera from laboratory culture, plankton tows, and recent sediment: implications for the reconstruction of paleoclimatic conditions and the global carbon cycle. Journal of Foraminiferal Research, 15: 302-320. 
Brock, J.C.; McClain, C.R.; Luther, M.E.; and Hay, W.W. 1991. The phytoplankton bloom in the northwest Arabian Sea during the southwest monsoon of 1979. Journal of Geophysical Research, 96: 20,623-20,642.

Brock, J.C. and McClain, C.R. 1992. Interannual variability in phytoplankton blooms observed in the northwestern Arabian Sea during the southwest monsoon. Journal of Geophysical Research, 97: 753-750.

Bouvier-Soumagnac, Y. and Duplessy, J-C. 1985. Carbon and oxygen isotopic composition of planktonic foraminifera from laboratory culture, plankton tows and Recent sediment: Implications for the reconstruction of paleoclimatic conditions and of the global carbon cycle. Journal of Foraminiferal Research, 15: 302-320.

Clemens, S.C.; Prell, W.L.; Murray, D.G.; Shimmield, D. and Weedon, G. 1991. Forcing mechanisms of the Indian Ocean Monsoon. Nature, 353: 720-725.

Conkright, M.E.; Levitus, S.; and Boyer, T.P. 1994. World Ocean Atlas 1994, Volume 1: Nutrients. NOAA Atlas NESDIS 1 (1994, 162 pp.)

Curry, W.B. and Matthews, R.K. 1981. Equilibrium ${ }^{18}$ O fractionation in small size fraction planktic foraminifera: evidence from Recent Indian Ocean sediments. Marine Micropaleontology, 6: 327-337.

Curry, W.B. and Matthews, R.K. 1981. Paleo-oceanographic utility of oxygen isotopic measurements of planktic foraminifera: Indian Ocean core-top evidence. Palaeogeography, Palaeoclimatology, Palaeoecology, 33: 173-191.

Curry, W.B.; Thunell, R.C. and Honjo, S. 1983. Seasonal changes in the isotopic composition of planktonic foraminifera collected in Panama Basin sediment traps. Earth and Planetary Science Letters, 64: 33-43.

Curry, W.B.; Ostermann, D.R.; Guptha, M.V.S. and Ittekot, V. 1992. Foraminiferal production and monsoonal upwelling in the Arabian Sea: evidence from sediment traps. In: C.P. Summerhayes, W.L. Prell, and K-C Emeis, (eds). Upwelling Systems: Evolution Since the Early Miocene. Geological Society Special Publication, London , 64: 93-106.

Curry, W.B. (in press) Late Quaternary Deep Circulation in the Western Equatorial Atlantic.

Dunbar, R.B. 1983. Stable isotope record of upwelling and climate from Santa Barbara Basin, California. In: E. Suess and J. Thiede (eds). Coastal Upwelling: Its Sedimentary Record, Part B. Plenum Press: New York, pp. 217-246.

Duplessy, J-C; Bé, A.W.H.; Blanc, P.L. 1981. Oxygen and carbon isotopic composition and biogeographic distribution of planktonic foraminifera in the Indian Ocean. Palaeogeography, Palaeoclimatology, Palaeoecology, 33: 9-47.

Emiliani, C. 1954. Depth habitats of some species of pelagic foraminifera as indicated by oxygen isotope ratios. American Journal of Science, 252: 149-158.

Emiliani, C. 1955. Pleistocene temperatures. Journal of Geology, 63: 538-578. 
Emiliani, C. 1966. Paleotemperature analysis of Caribbean Cores P6304-8 and P6304-9 and a generalized temperature curve for the past 425,000 years. Journal of Geology, 74: 109-134.

Epstein, S.; Buchsbaum, R.; Lowenstam, H.A. and Urey, H.C. 1953. Revised carbonate-water isotopic temperature scale. Geological Society of America Bulletin, 64: 1315-1326.

Epstein, S. and Mayeda, T. 1953. Variation of ${ }^{18} \mathrm{O}$ content of waters from natural sources. Geochimica et Cosmochimica Acta, 27: 213-224.

Erez, J. and Honjo, S. 1981. Comparison of the isotopic composition of planktonic foraminifera in plankton tows, sediment traps, and sediments. Palaeogeography, Palaeoclimatology, Palaeoecology, 33: 129-156.

Erez, J. and Luz, B. 1983. Experimental paleotemperature equation for planktonic foraminifera. Geochimica et Cosmochimica Acta, 4: 1025-1031.

Fairbanks, R.G., P.H. Wiebe, and A.W.H. Bé. 1980. Vertical distribution and isotopic composition of living planktonic foraminifera in the western North Atlantic.

Science 207: 61.

Fairbanks, R.G., M. Sverdlove, R. Free, P.H. Wiebe and A.W.H. Bé. 1982. Vertical distribution and isotopic composition of living planktonic foraminifera from the Panama Basin. Nature, 298: 841.

Ganssen, G. and Sarnthein, M. 1983. Stable-isotope composition of foraminifers: the surface and bottom water record of coastal upwelling. In: E. Suess and J. Thiede (eds) Coastal upwelling: Its Sedimentary Record, Part A , Plenum Press: New York, pp. 99-121.

Haake, B.; Ittekkot, V.; Rixen, T.; Ramaswamy, V.; Nair, R.R.; Curry, W.B. 1993. Seasonality and interannual variability of particle fluxes to the deep Arabian Sea. Deep Sea Research, 40 (3): 1323-1344.

Hankin, S.; Davison, J.; and Harrison, D.E. 1996. "Web Visualization and Extraction of Gridded Climate Data with the FERRET Program", [http://www.pmel.noaa.gov/ferret/ferret_climate_server.html].

Hastenrath, S. and Lamb, P.J. 1979. Climatic Atlas of the Indian Ocean, Vol. 1. University of Wisconsin Press: Madison, $109 \mathrm{pp}$.

Hecht, A.D. and Savin, S.M. 1970. Oxygen-18 studies of Recent planktonic foraminifera: Comparisons of phenotypes and of test parts. Science, 170: 69-71.

Hecht, A.D. and Savin, S.M. 1972. Phenotypic variation and oxygen isotope ratios in Recent planktonic foraminifera. Journal of Foraminiferal Research, 2: 55-67.

Hemleben, C. and Spindler, M. 1983. Recent advances in research on living planktonic foraminifera, In: J.T. Meulenkamp (ed), Reconstruction of marine paleoenvironments. Utrecht Micropaleontological Bulletins, 30: 141-170. 
Honjo, S. and Doherty, K.W. 1988. Large aperture time-series sediment traps: design objective, construction and application. Deep Sea Research., 35: 133-149.

Kahn, M.I. 1979. Non-equilibrium oxygen and carbon isotopic fractionation in tests of living planktonic foraminifera. Oceanologica Acta, 2: 195-200.

Kahn, M.I. and Williams, D.F. 1981. Oxygen and carbon isotopic composition of living planktonic foraminifera from the northeast Pacific Ocean. Palaeogeography, Palaeoclimatology, Palaeoecology, 33: 47-71.

Kroon, D. and Ganssen, G. 1989. Northern Indian Ocean upwelling cells and the stable isotope composition of living planktonic foraminifera. Deep Sea Research, 36: 1219-1236.

Levitus, S. and Boyer, T.P. World Ocean Atlas 1994, Volume 2: Oxygen. NOAA Atlas NESDIS 2. 202 pp.

Levitus, S.; Burgett, R.; and Boyer, T.P. 1994. World Ocean Atlas 1994, Volume 3: Salinity. NOAA Atlas NESDIS 3.

Levitus, S.; Boyer, T.P.; and Antonov, J. 1994. World Ocean Atlas 1994, Volume 4: Temperature. NOAA Atlas NESDIS 4. 129 pp.

Levitus, S.; Boyer, T.P.; and Antonov, J. 1994. World Ocean Atlas 1994, Volume 5: Interannual Variability of Upper Ocean Thermal Structure. NOAA Atlas NESDIS 5. $176 \mathrm{pp}$.

Nair, R.R.; Ittekkot, V.; Manganini, S.J.; Ramaswamy, V.; Haake, B.; Degens, E.T.; Desai, B.N. and Honjo, S. 1989. Increased particle flux to the deep ocean related to monsoons. Nature, 338: 749-751.

O'Neil, J.R.; Clayton, R.N. and Mayeda, T.K. 1969. Oxygen isotope fractionation in divalent metal carbonates. Journal of Chemical Physics, 51: 5547-5558.

Prell, W.L. 1984. Variation in the monsoonal upwelling: A response to changing solar radiation. In: Climate Processes and Climate Sensitivity, American Geophysical Union Geophysical Monograph Series 29. pp. 48-57.

Prell, W.L. and Curry, W.B. 1981. Faunal isotopic indices of monsoonal upwelling: western Arabian Sea. Oceanologica Acta, 4: 91-98.

Sautter, L.R. and Thunell, R.C. 1989. Seasonal succession of planktonic foraminifera: Results from a four-year time-series sediment trap experiment in the northeast Pacific. Journal of Foraminiferal Research. 19: 253-267.

Sautter, L.R. and Thunell, R.C. 1991. Seasonal variability in the $\delta^{18} \mathrm{O}$ and $\delta^{13} \mathrm{C}$ of planktonic foraminifera from an upwelling environment: sediment trap results from the San Pedro Basin, Southern California Bight. Paleoceanography, 6: 307-334.

Sautter, L.R. and Thunell, R.C. 1991. Planktonic foraminiferal response to upwelling and seasonal hydrographic conditions: sediment trap results from San Pedro Basin, Southern California Bight. Journal of Foraminiferal Research, 21: 347-363. 
Savin, S.M. and Douglas, R.G. 1973 . Stable isotope and magnesium geochemistry of Recent planktonic foraminifera from the South Pacific. Geological Society of America Bulletin, 84: 2327-2342.

Schweitzer, P.N. 1993. Modern Average Global Sea-Surface Temperature, U.S. Geological Survey Digital Data Series DDS-10.

Shackleton, N.J.; Wiseman, J.D.H.; and Buckly, H.A. 1973. Non-equilibrium isotopic fractionation between seawater and planktonic foraminiferal tests. Nature, 242: 177-179.

Smith, E. 1992. A User's Guide to the NOAA Advanced Very High Resolution Radiometer Multichannel Sea Surface Temperature Data Set. The University of Miami--Rosenstiel School of Marine and Atmospheric Science, distributed by the Physical Oceanography Distributed Active Archive Center, Jet Propulsion Laboratory, California Institute of Technology.

Spero, H.J. and Lea, D.W. 1993. Intraspecific stable isotope variability in the planktic foraminifera Globigerinoides sacculifer: Results from laboratory experiments. Marine Micropaleontology, 22: 221-234.

Spero, H.J. and Lea, D.W. 1996. Experimental determination of stable isotope variability in Globigerina bulloides: implications from paleoceanographic reconstructions. Marine Micropaleontology, 28: 231-246.

Steens, T.N.F., Ganssen, G. and Kroon, D. 1992. Oxygen and carbon isotopes in planktonic foraminifera as indicators of upwelling intensity and upwelling-induced high productivity sediments from the Northwestern Arabian Sea. In: C.P. Summerhayes, W.L. Prell, and K-C Emeis, (eds). Upwelling Systems: Evolution Since the Early Miocene. Geological Society Special Publication, London , 64: 107-119.

Thunell, R.C. and Reynolds, L.A. 1984. Sedimentation of planktonic foraminifera: seasonal changes in species flux in the Panama Basin. Micropaleontology, 30: 241-260.

Thunell, R.C. and Sautter, L.R. 1992. Planktonic foraminiferal faunal and stable isotopic indices of upwelling: a sediment trap study in the San Pedro Basin, Southern California Bight. In: C.P. Summerhayes, W.L. Prell, and K-C Emeis, (eds). Upwelling Systems: Evolution Since the Early Miocene. Geological Society Special Publication, London, 64: 77-91.

Vergnaud-Grazzini, C. 1976. Non-equilibrium isotopic compositions of shells of planktonic Foraminifera in the Meditteranean Sea. Palaeogeography, Palaeoclimatology, Palaeoecology, 20: 263-276.

Weber, J.N. and Woodhead, P.M.J. 1971. Diurnal variations in the isotopic composition of dissolved inorganic carbon in seawater from coral reef environments. Geochimica et Cosmochimica Acta, 35: 891-902.

Wefer, G.; Dunbar, R.B.; and Suess, E. 1983. Stable isotopes of foraminifers off Peru recording high fertility and changes in upwelling history. In: E. Suess and J. Thiede (eds), Coastal Upwelling: Its Sedimentary Record. Plenum: New York, pp. 295-308. 
Williams, D.F. 1976. Planktonic Foraminiferal Paleoecology in Deep-Sea Sediments of the Indian Ocean. Thesis, University of Rhode Island, Graduate School of Oceanography, Kingston, RI. 283 pp.

Williams, D.F. and Healy-Williams, N. 1980. Oygen isotopic-hydrographic relationships among recent planktonic foraminifera from the Indian Ocean. Nature, 283: 848852 .

Williams, D.F.; Sommer, M.A.; and Bender, M.L. 1977. Carbon isotopic compositions of Recent planktonic foraminifera of the Indian Ocean. Earth and Planetary Science Letters, 36: 391-403.

Williams, D.F.; Bé, A.W.H.; and Fairbanks, R.G. 1981. Seasonal stable isotopic variations in living planktonic foraminifera from Bermuda plankton tows. Palaeogeography, Palaeoclimatology, Palaeoecology, 33: 71-102.

Wong, W.W. and Sackett, W. 1987. Fractionation of stable carbon isotopes by marine phytoplankton. Geochimica et Cosmochimica Acta, 42(12): 1809-1817.

Wyrtki, K. 1971. Oceanographic Atlas of the International Indian Ocean Expedition, National Science Foundation, Washington, D.C. 
FIGURES 


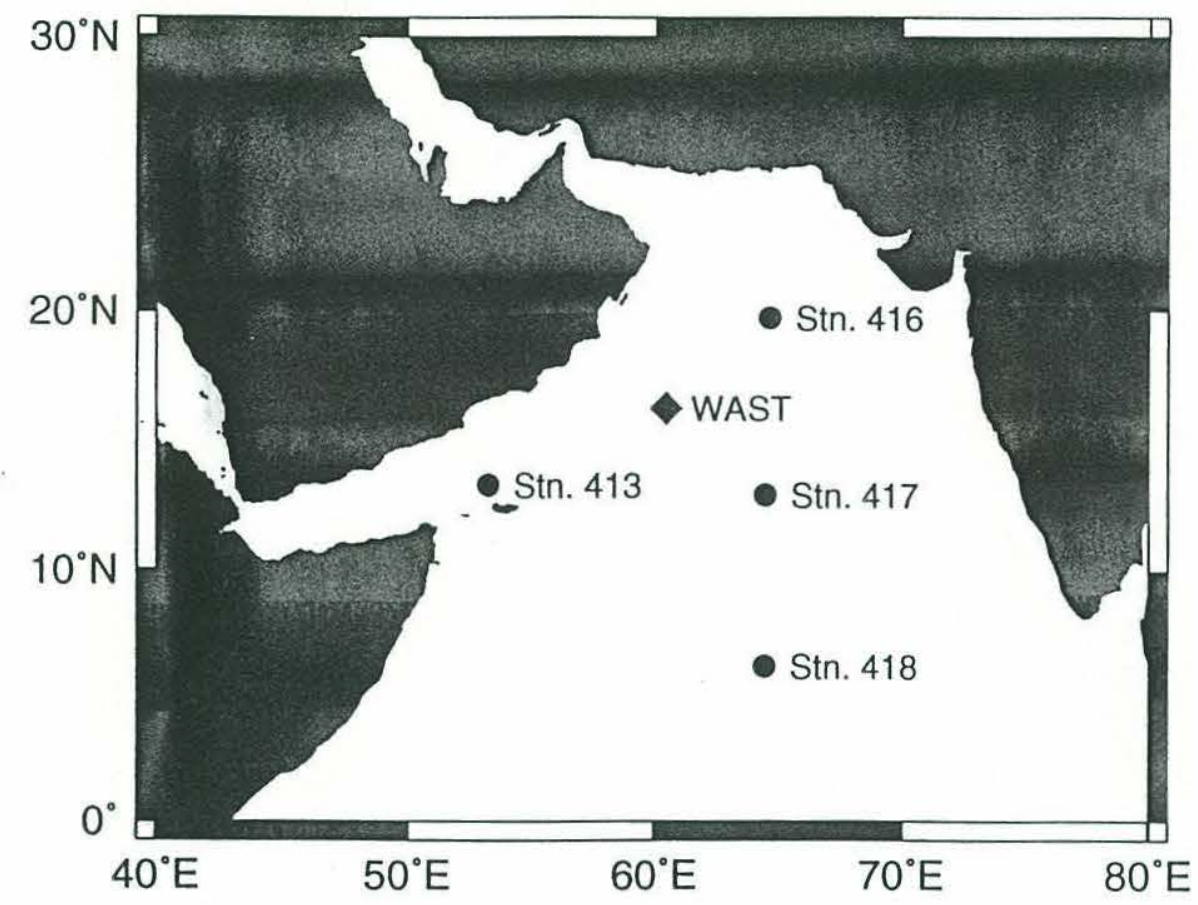

Figure 1 The western Arabian Sea. $\rightarrow$ indicates the location $\left(16^{\circ} 19^{\prime} \mathrm{N}\right.$, $60^{\circ} 28^{\prime} \mathrm{E}$ ) of the Western Arabian Sea sediment Trap (WAST). $\bullet$ indicates GEOSECS station locations. Solid arrows show the direction of the winds during the southwest monsoon, while dashed arrows show the direction of the winds during the northeast monsoon. 


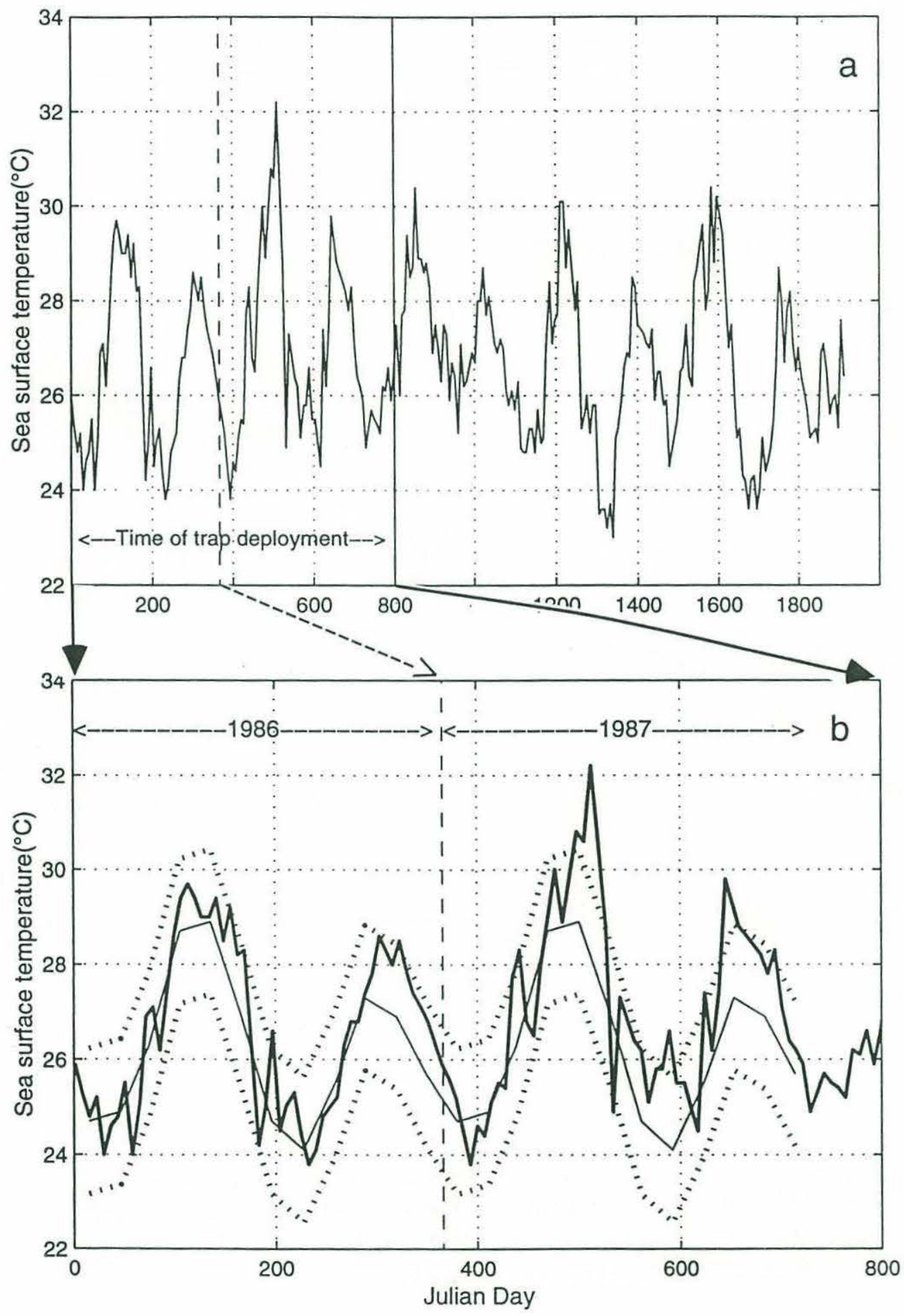

Figure 2 a) AVHRR sea surface temperatures in the western Arabian Sea beginning January 1,1986 that show the seasonal cycles during a period of $>5$ years. The steep drops in temperature $\left(\sim 4^{\circ} \mathrm{C}\right)$ indicate the onset of the southwest monsoon. b) Enlarged section of (a) showing the temperature record (bold line) during the time of the trap deployment. The dashed lines represent two standard deviations from the ten-year average (light line). The 1987 monsoon season has significantly warmer temperatures than the multi-year record (a) and the ten-year average. 


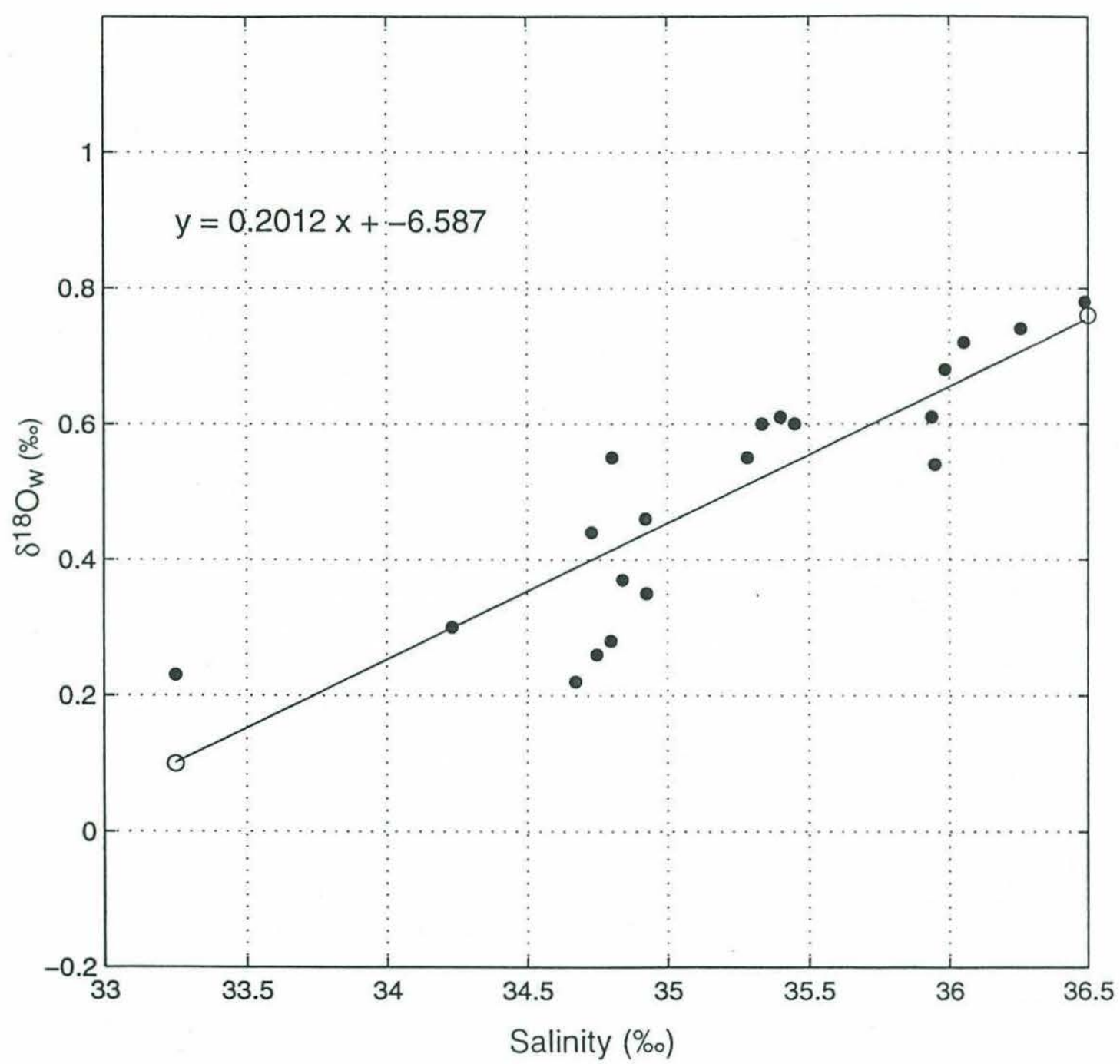

Figure 3 Linear regression of salinity and $\delta^{18} \mathrm{O}_{\mathrm{w}}$ for shallow $(<200 \mathrm{~m})$ Indian Ocean GEOSECS stations. The regression gives a salinity: $\delta^{18} \mathrm{O}_{w}$ relationship which can be used to calculate $\delta^{18} \mathrm{O}_{\mathrm{w}}$ values for the study area, because the $\delta^{18} \mathrm{O}_{\mathrm{w}}$ is not measured directly. 

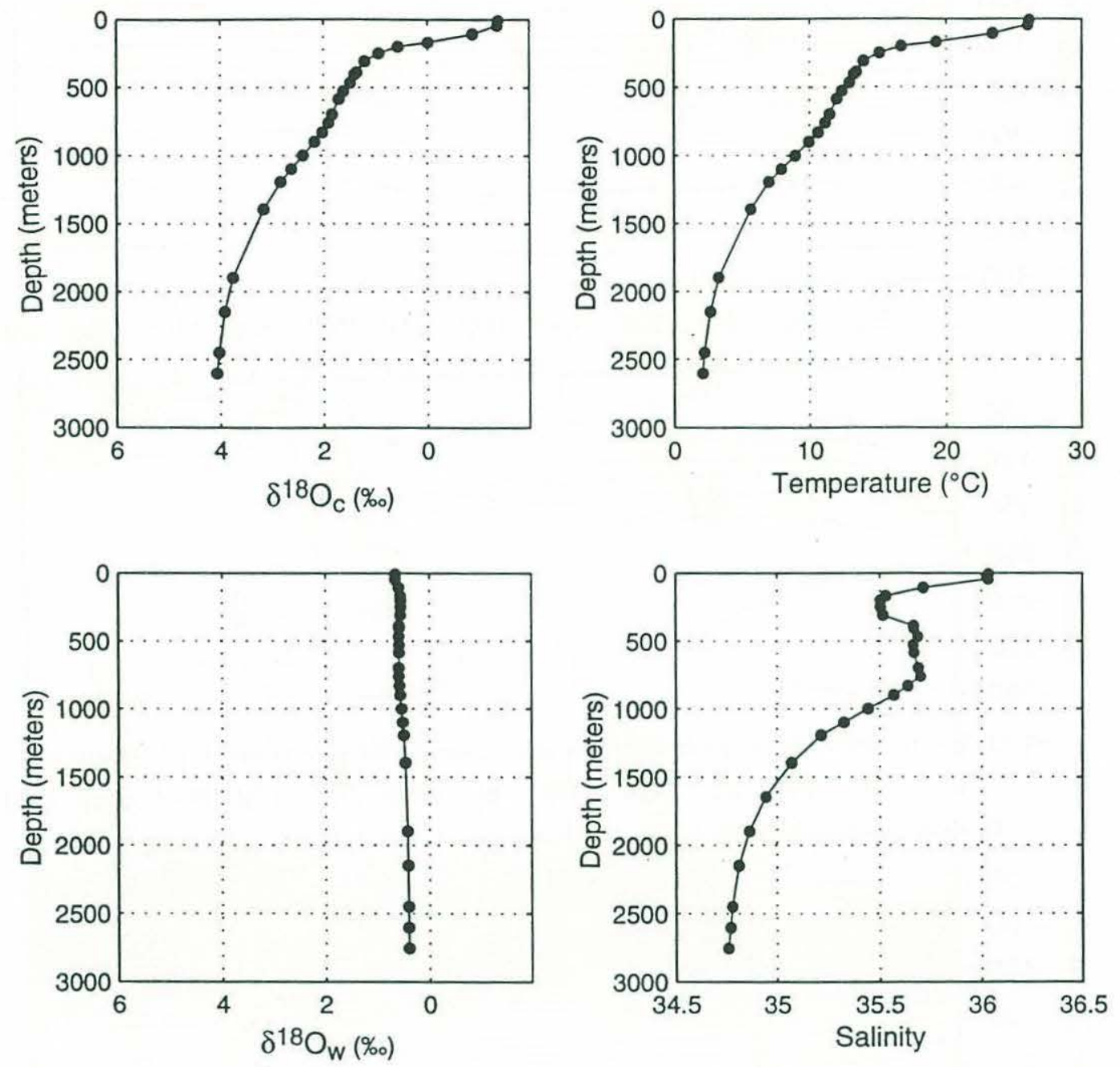

Figure 4 Profiles from GEOSECS Station 413 showing a) $\delta^{18} \mathrm{O}_{c}$, b) temperature, c) $\delta^{18} \mathrm{O}_{\mathrm{w}}$, and d) salinity. In general, the $\delta^{18} \mathrm{O}$ of calcite is affected by temperature and salinity. However, in the western Arabian Sea the effect of salinity is negligible. As can be seen from the profiles, the $\delta^{18} \mathrm{O}_{\mathrm{c}}$ and temperature are nearly identical, while the $\delta^{18} \mathrm{O}_{\mathrm{w}}$ and salinity have little to no effect on the $\delta^{18} \mathrm{O}_{\mathrm{c}}$ signal. 

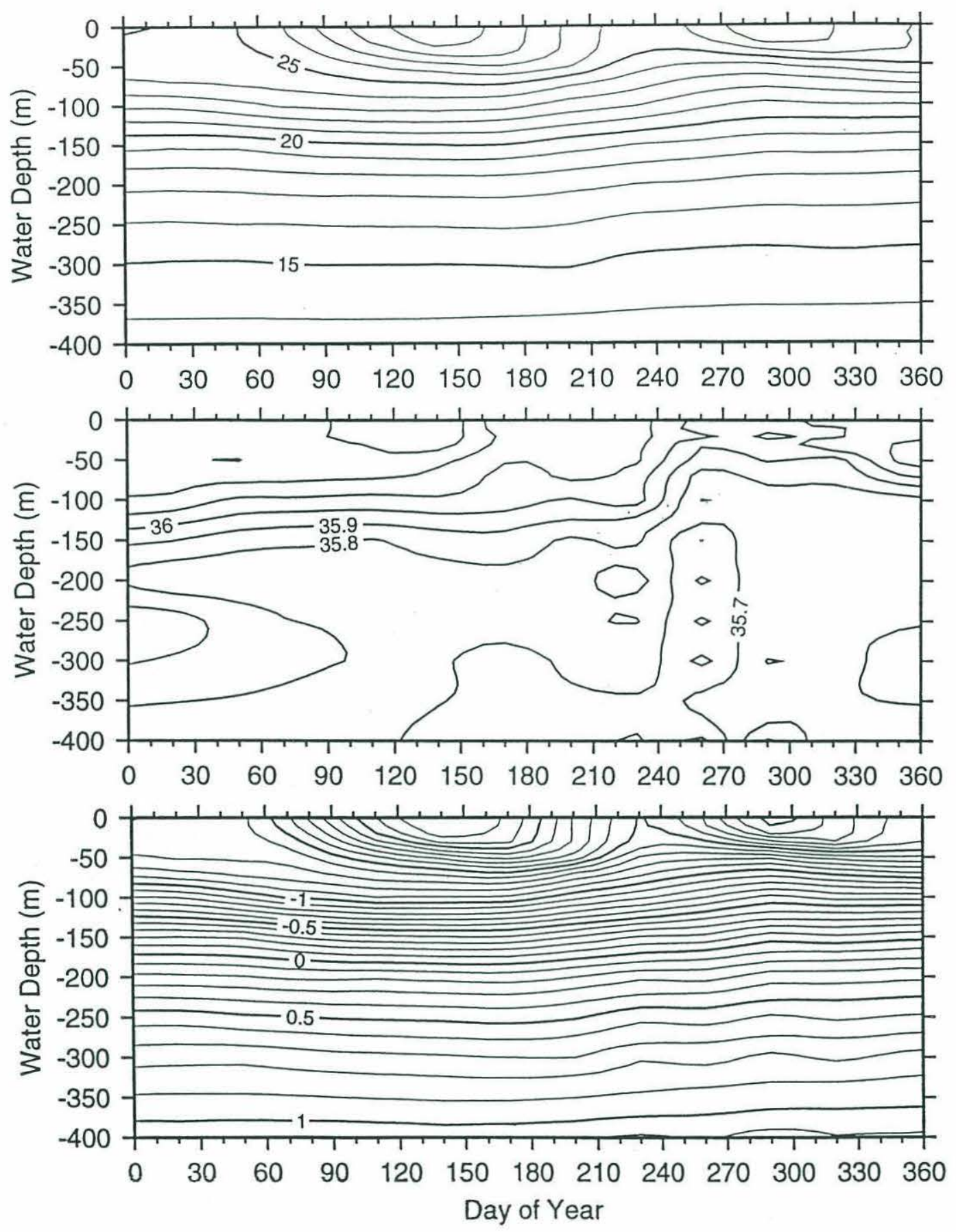

Figure 5 Contour plots of temperature, salinity and $\delta^{18} \mathrm{O}_{\mathrm{c}}$ made using the Levitus (1994) yearly averages for the area around the western Arabian Sea sediment trap. During the upwelling periods, the subsurface water rising to the surface is reflected in the upward bending of the isotherms $>25^{\circ} \mathrm{C}$, and in the equilibrium calcite $\delta^{18} \mathrm{O}$ values becoming more positive. 

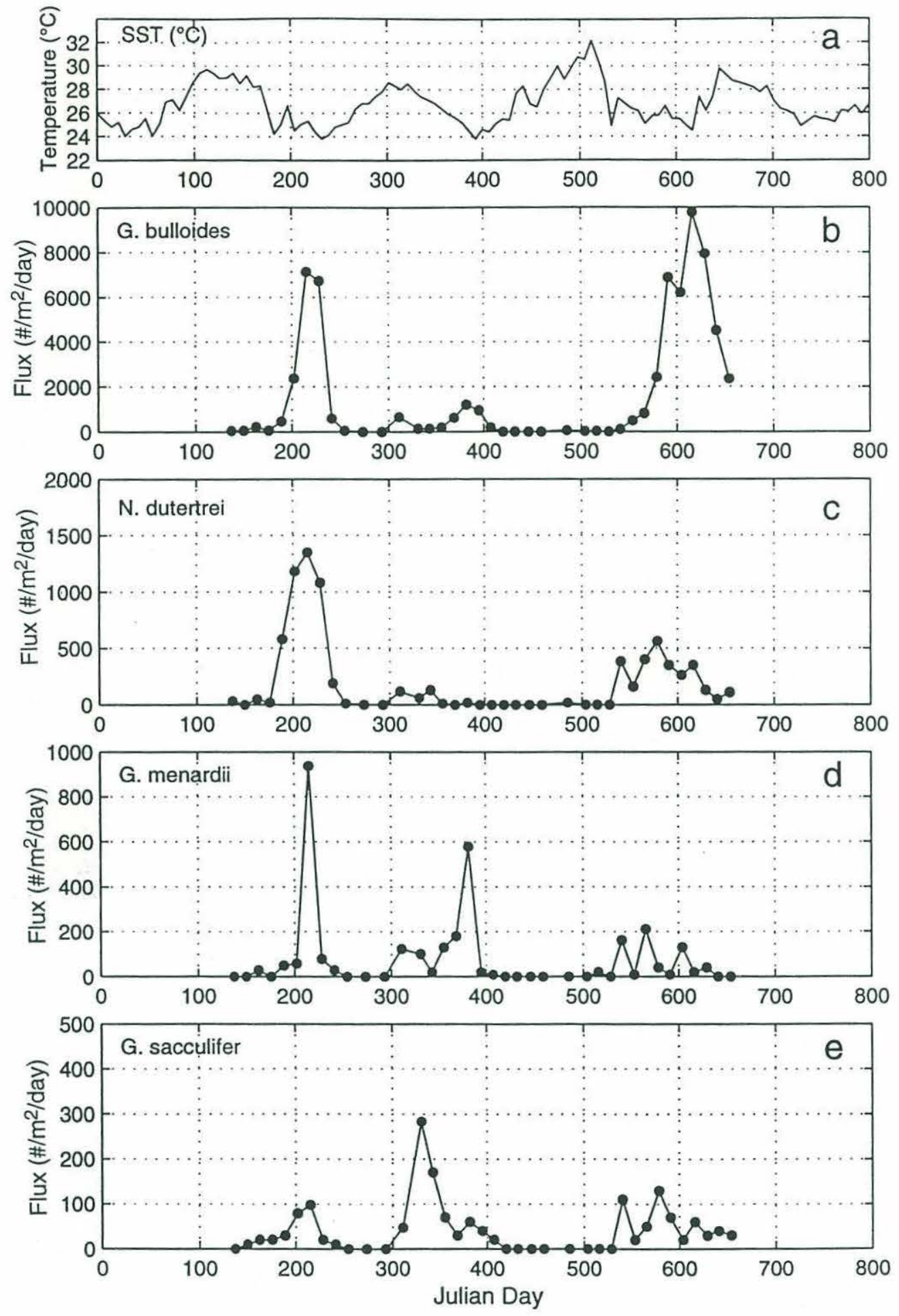

Figure 6 Flux $\left(\# / \mathrm{m}^{2} /\right.$ day) time series for all four species, showing increased production during both monsoon periods, especially the southwest monsoon (around Julian Days 200 and 570). The a) AVHRR sea surface temperature, b) G. bulloides, the most abundant species used as an upwelling indicator, c) $N$. dutertrei, d) G. menardii, e) G. sacculifer. Note the different vertical scales. 

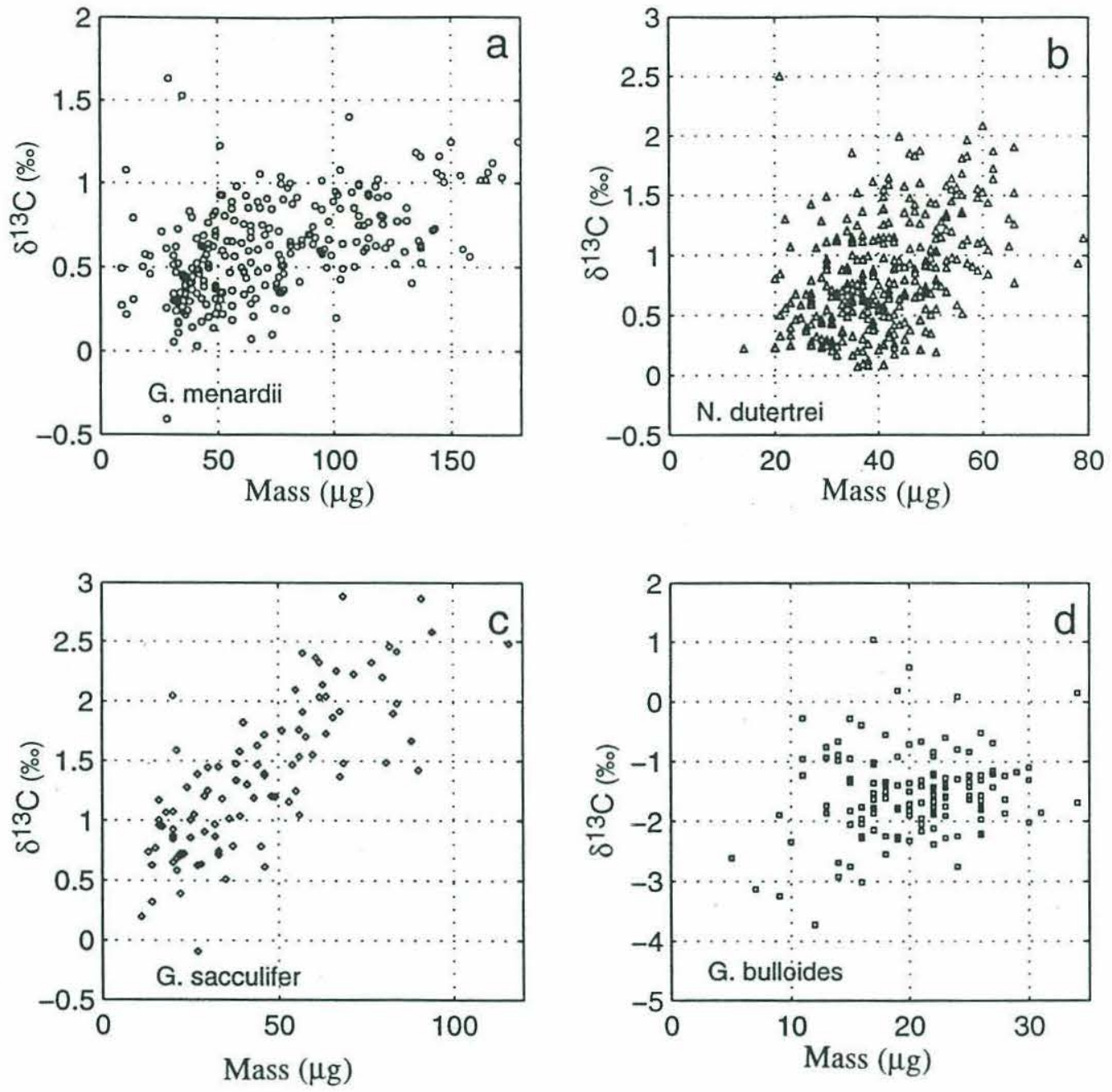

Figure $7 \delta^{13} \mathrm{C}$ vs. mass. All species show a general trend of higher $\delta^{13} \mathrm{C}$ with larger mass. a) G. menardii, b) $N$. dutertrei, c) G. sacculifer, d) G. bulloides 

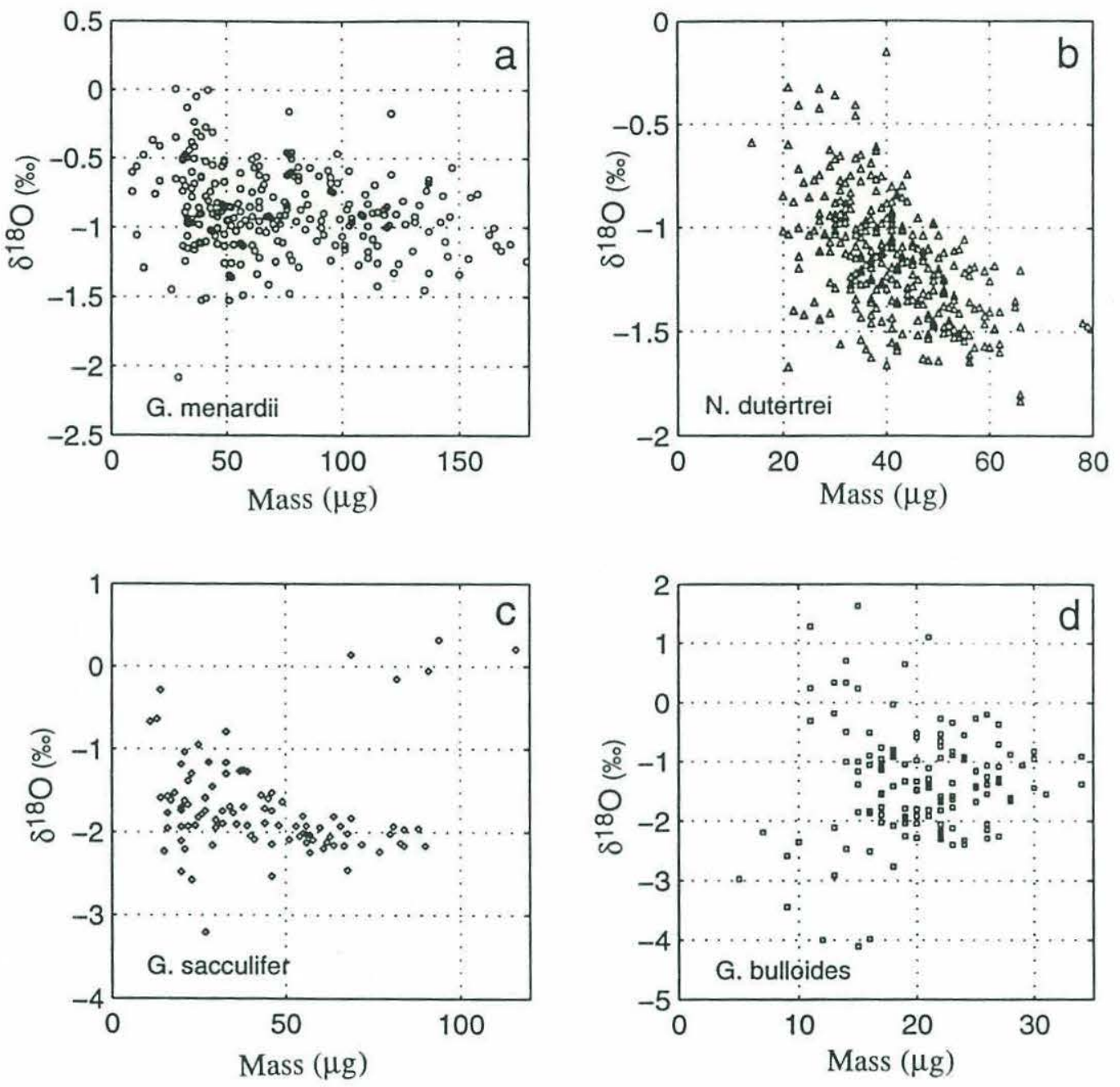

Figure $8 \delta^{18} \mathrm{O}$ vs. mass. a) $G$. menardii shows no change in $\delta^{18} \mathrm{O}$ with increasing mass, b) $N$. dutertrei and c) $G$. sacculifer show a negative correlation or "reverse trend", d) G. bulloides. 

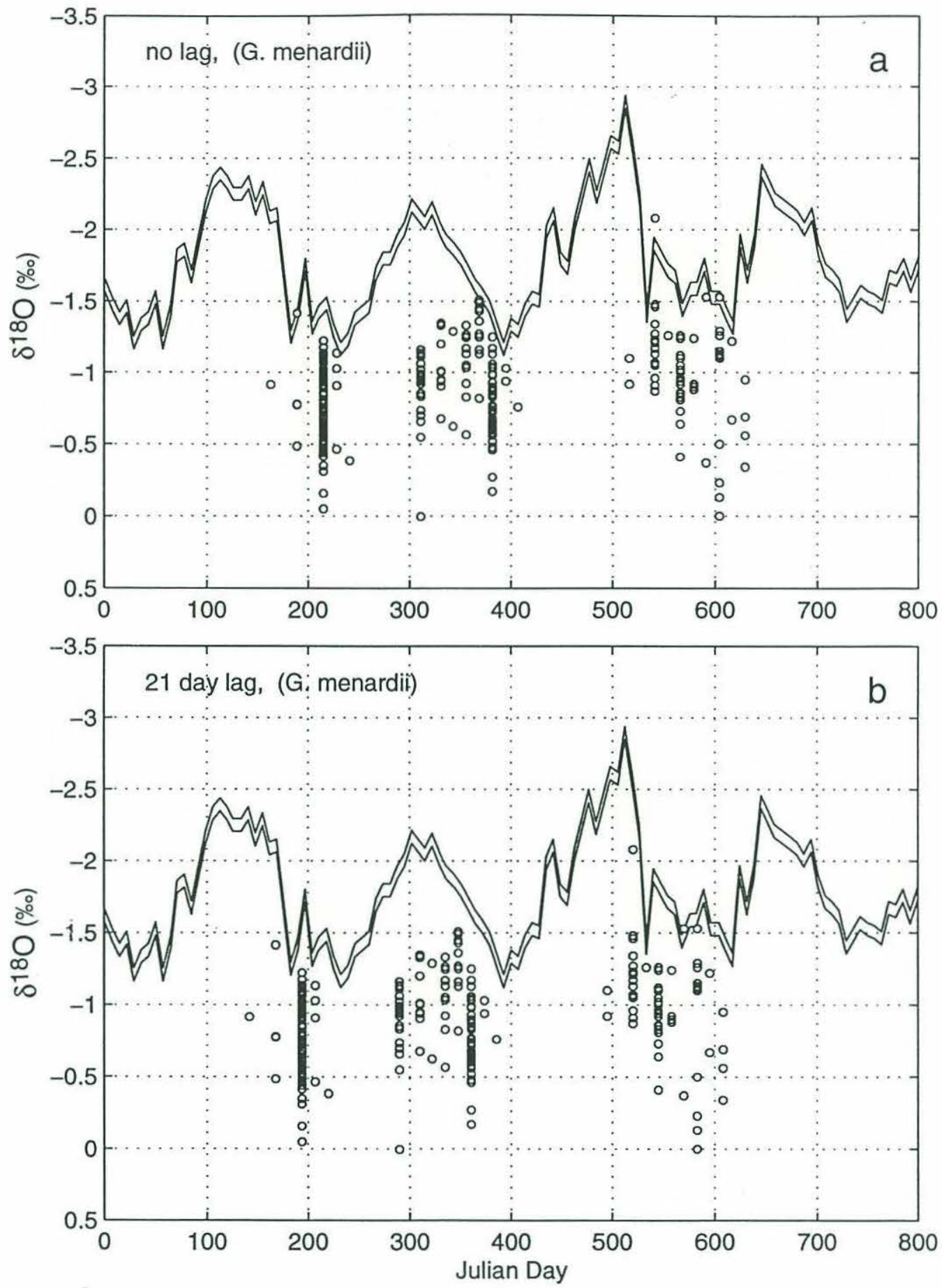

Figure 9 Time series oxygen isotopic composition for G. menardii, plotted with a band of equilibrium calcite SST values. Data presented with a) no lag, and b) 21 day lag to account for varying settling rates. When the lag is taken into account, all the values fall within equilibrium. 

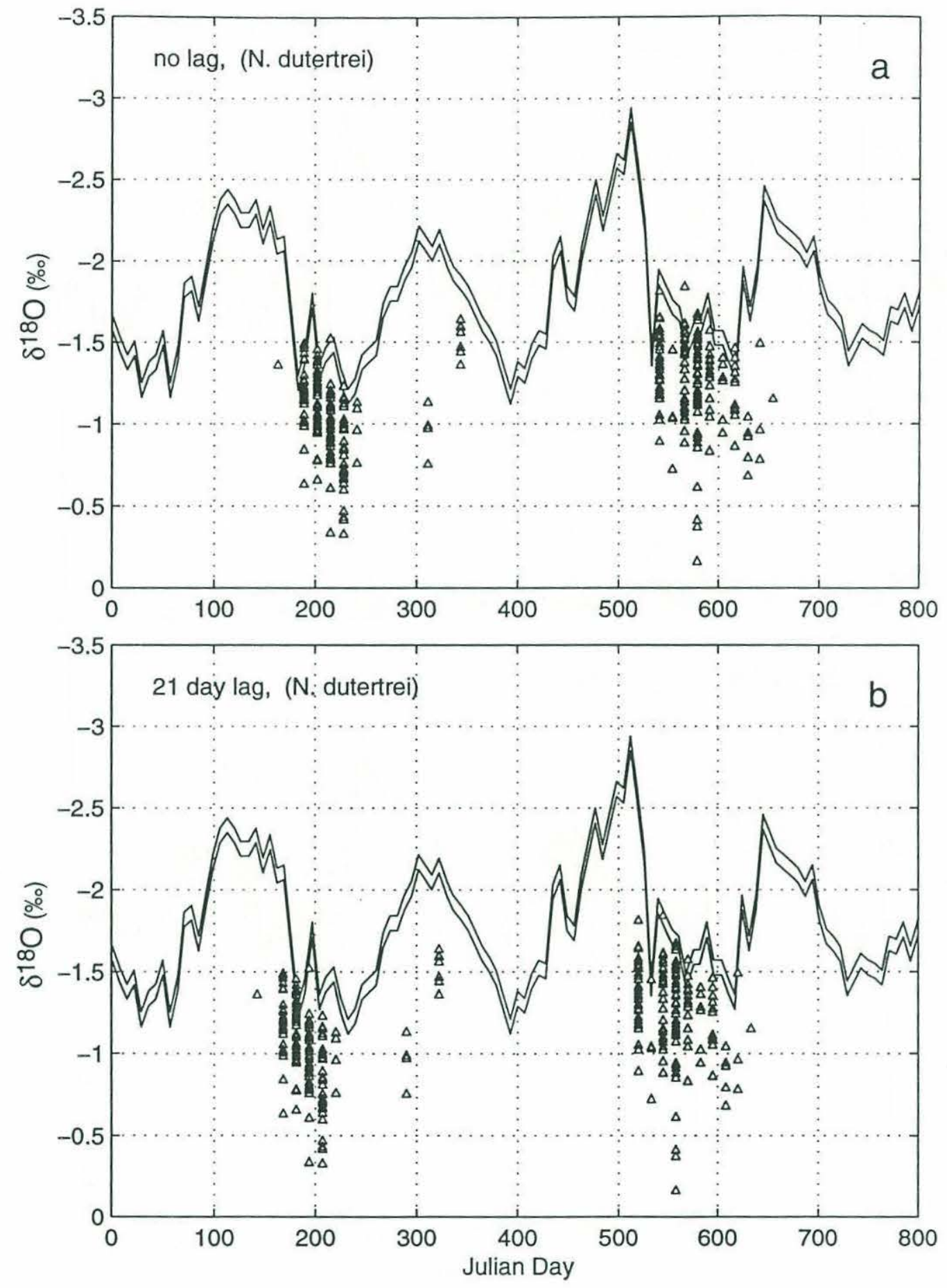

Figure 10 Time series oxygen isotopic composition for $N$. dutertrei plotted with a band of equilibrium calcite SST values. Data presented with a) no lag, and b) 21 day lag to account for varying settling rates. When the lag is taken into account, all the values fall within equilibrium. 

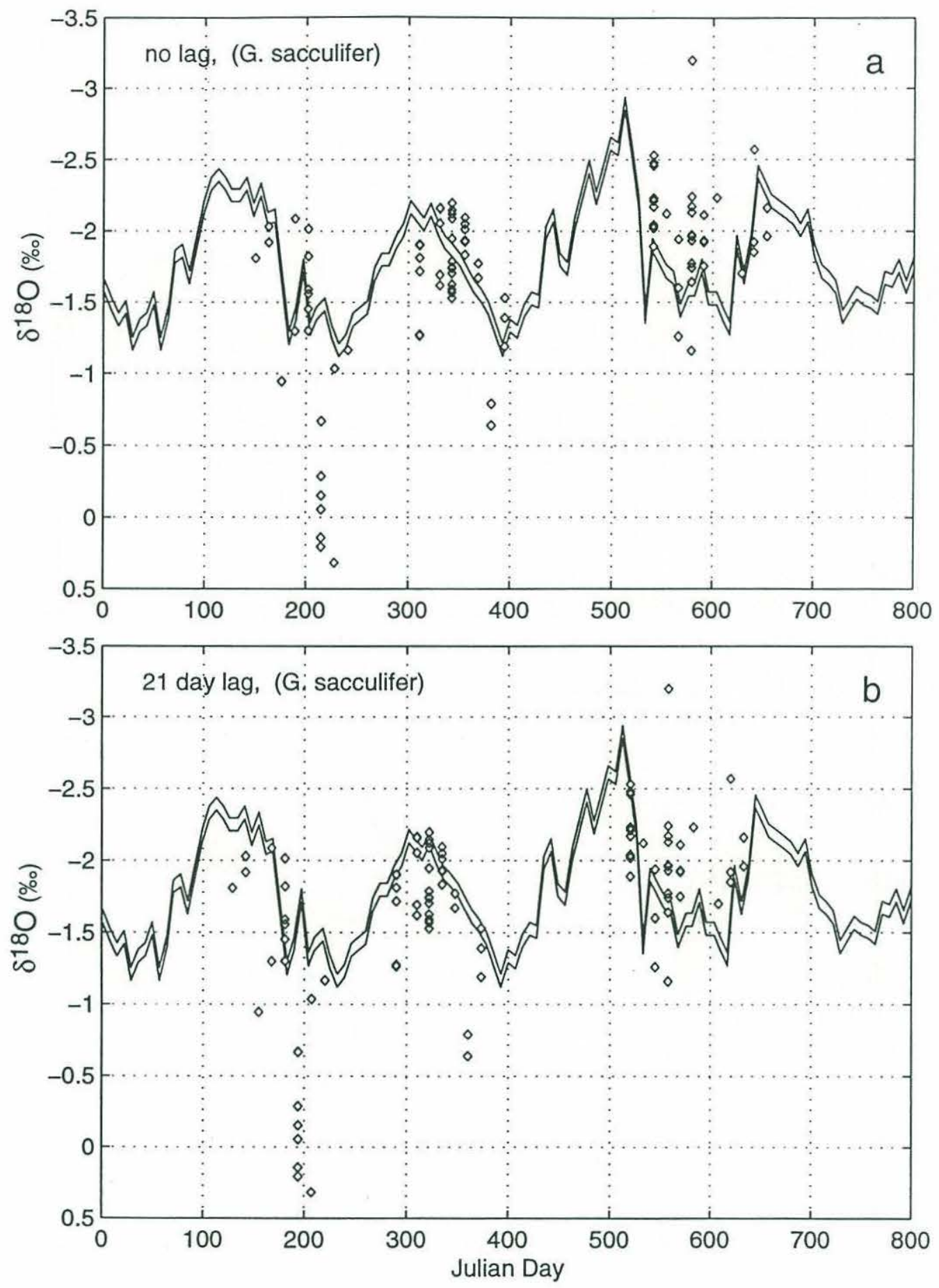

Figure 11 Time series oxygen isotopic composition for G. sacculifer plotted with a band of equilibrium calcite SST values. Data presented with a) no lag, and b) 21 day lag to account for varying settling rates. Even when a lag is applied, almost half of the values remain out of equilibrium, especially the individuals from the 1987 southwest monsoon. 

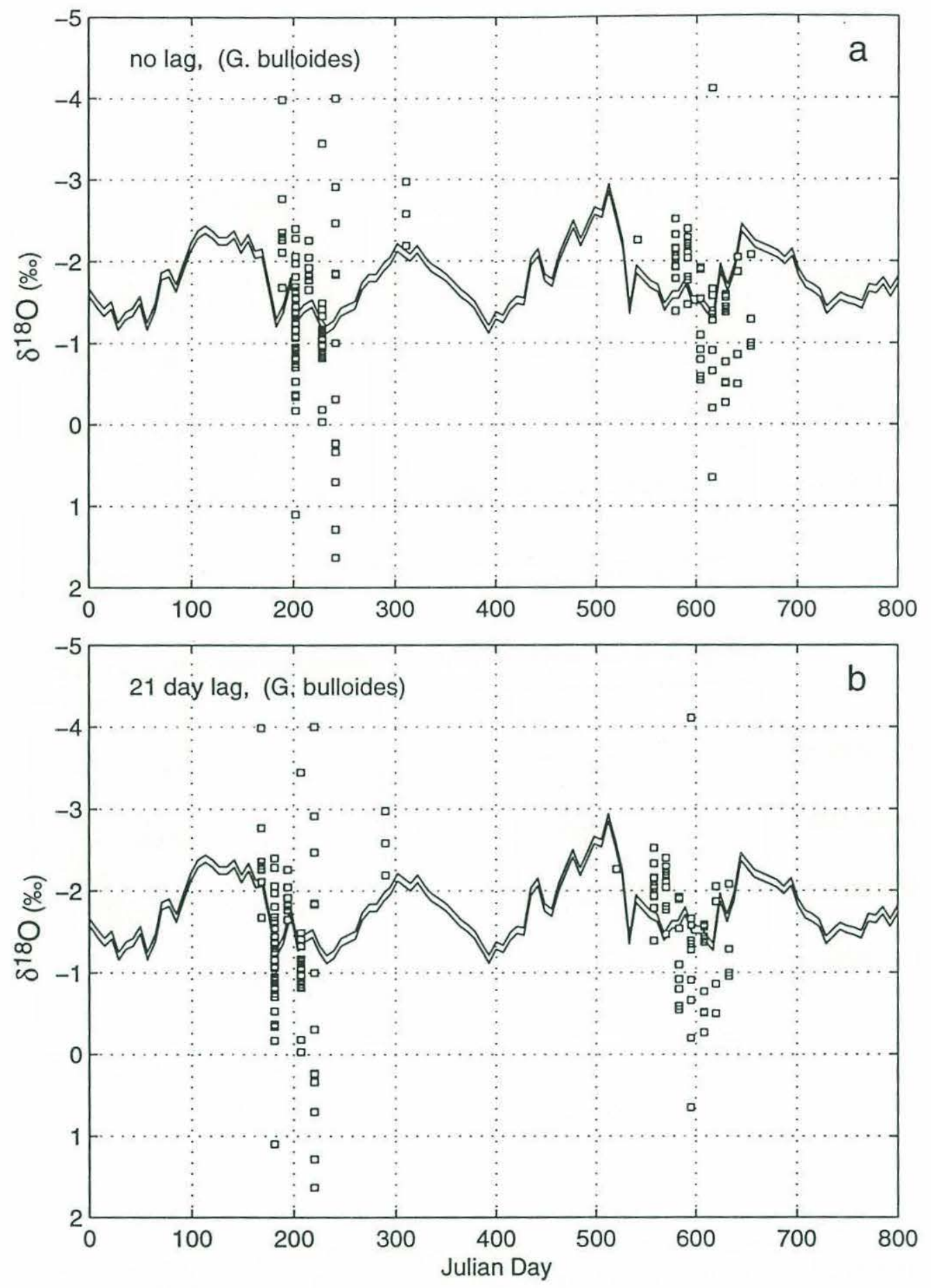

Figure 12 Time series oxygen isotopic composition for G. bulloides plotted with a band of equilibrium calcite SST values. Data presented with a) no lag, and b) 21 day lag to account for varying settling rates. Even when a lag is applied, almost half of the values remain out of equilibrium. The flux of this species is low during the northeast monsoon, so no data is available for this time period. 

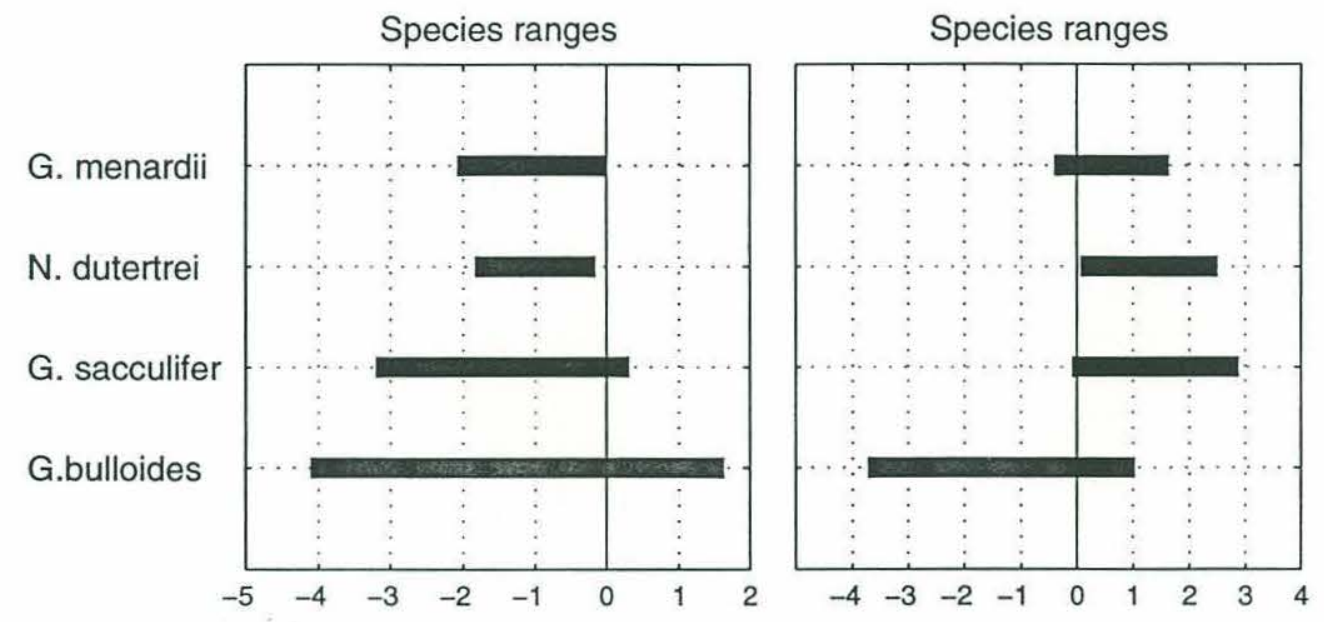

Average species ranges \pm 1 std dev

Average species ranges \pm 1 std dev
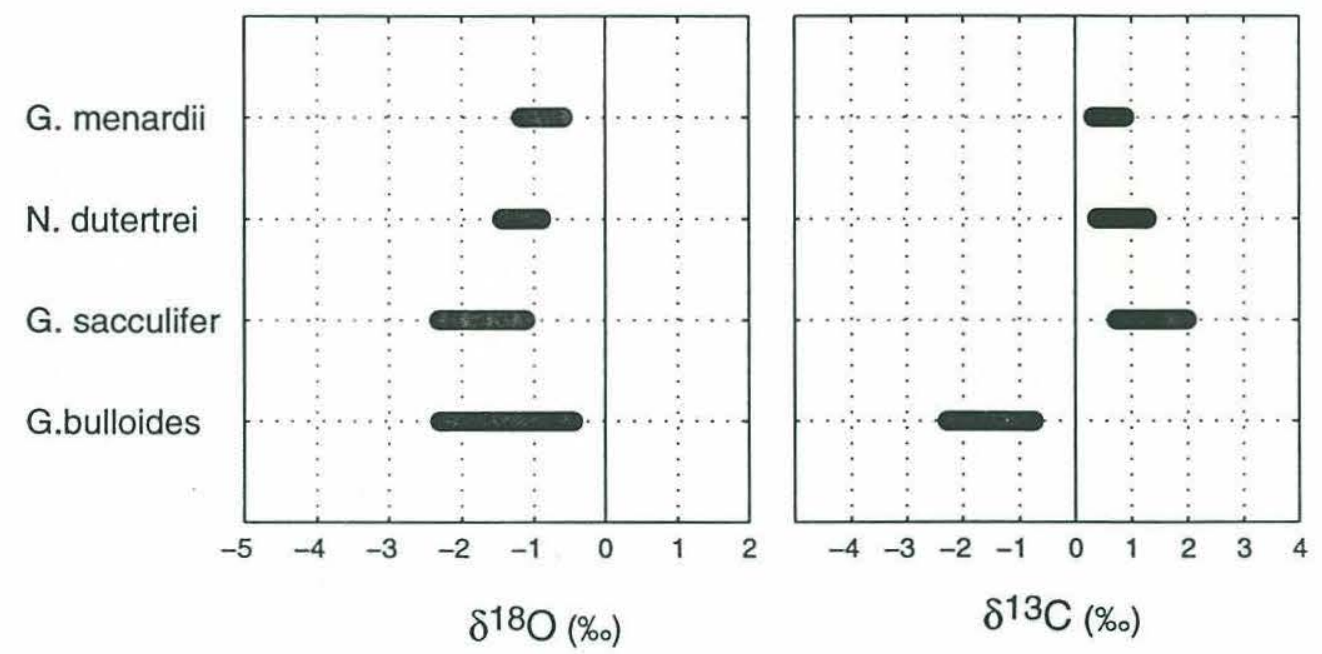

Figure 13 Species isotopic ranges and averages for all four species. The thermocline dwellers ( $G$. menardii and $N$. dutertrei) have narrower ranges than the surface dwellers ( $G$. sacculifer and $G$. bulloides). G. bulloides has an extremely wide range of $\delta^{13} \mathrm{C}$ and $\delta^{18} \mathrm{O}$ values, with an unusually low $\delta^{13} \mathrm{C}$ average. The average species values are the mean values \pm 1 standard deviation. 

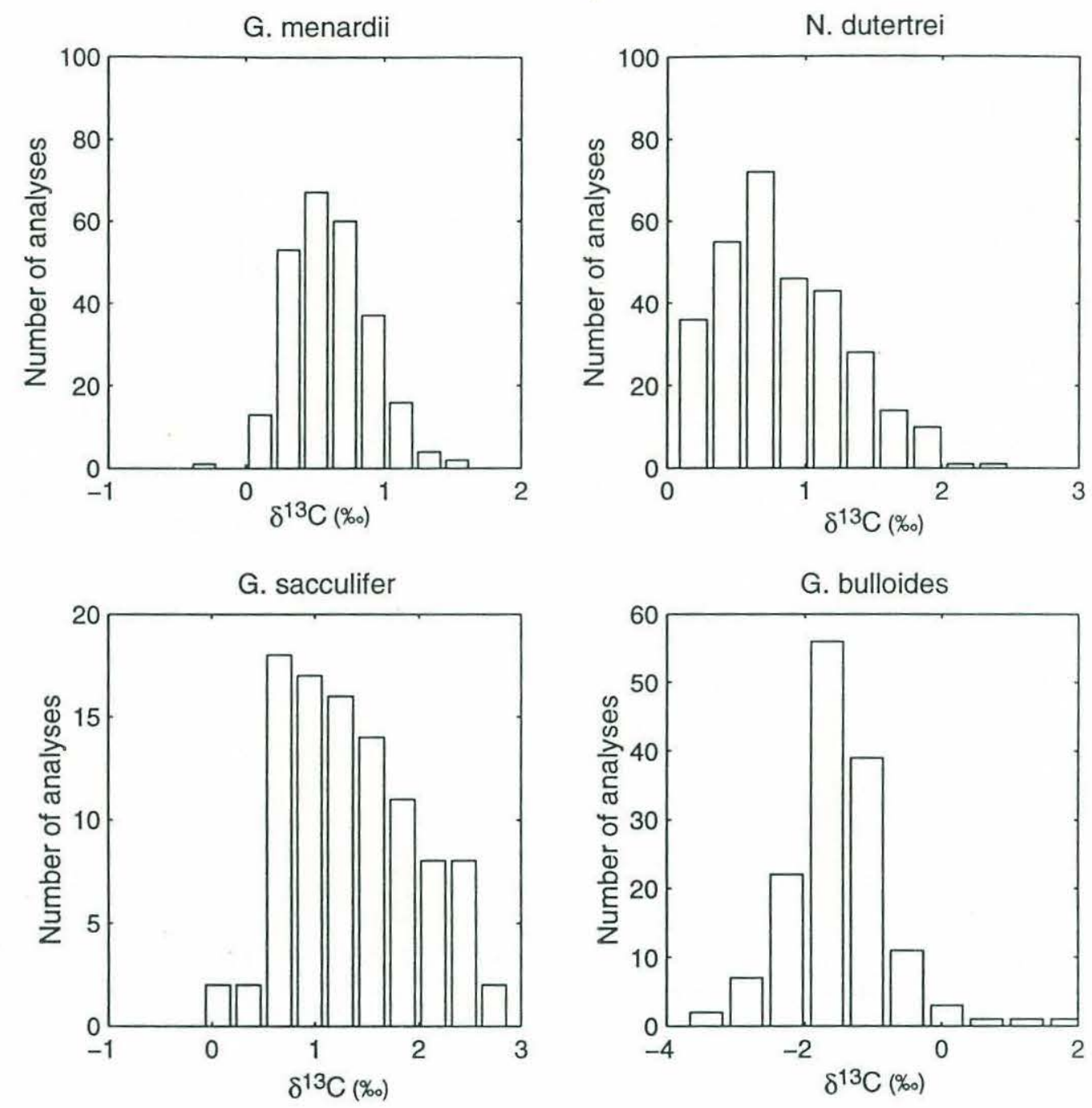

Figure 14 Histograms of the $\delta^{13} \mathrm{C}$ ranges for the four species showing the distribution of values for the analyses. 

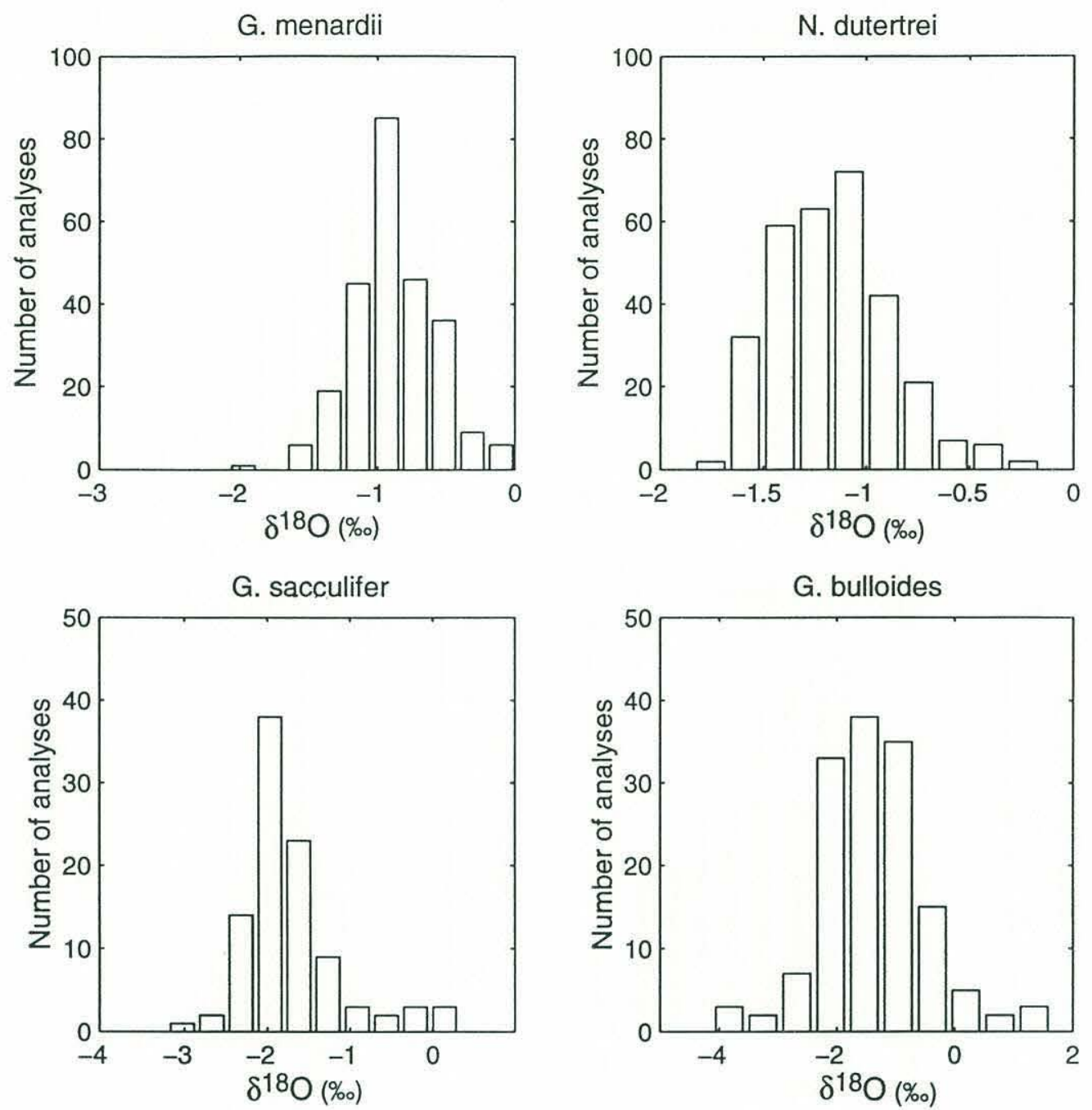

Figure 15 Histograms of the $\delta^{18} \mathrm{O}$ ranges for the four species showing the distribution of values for the analyses. 

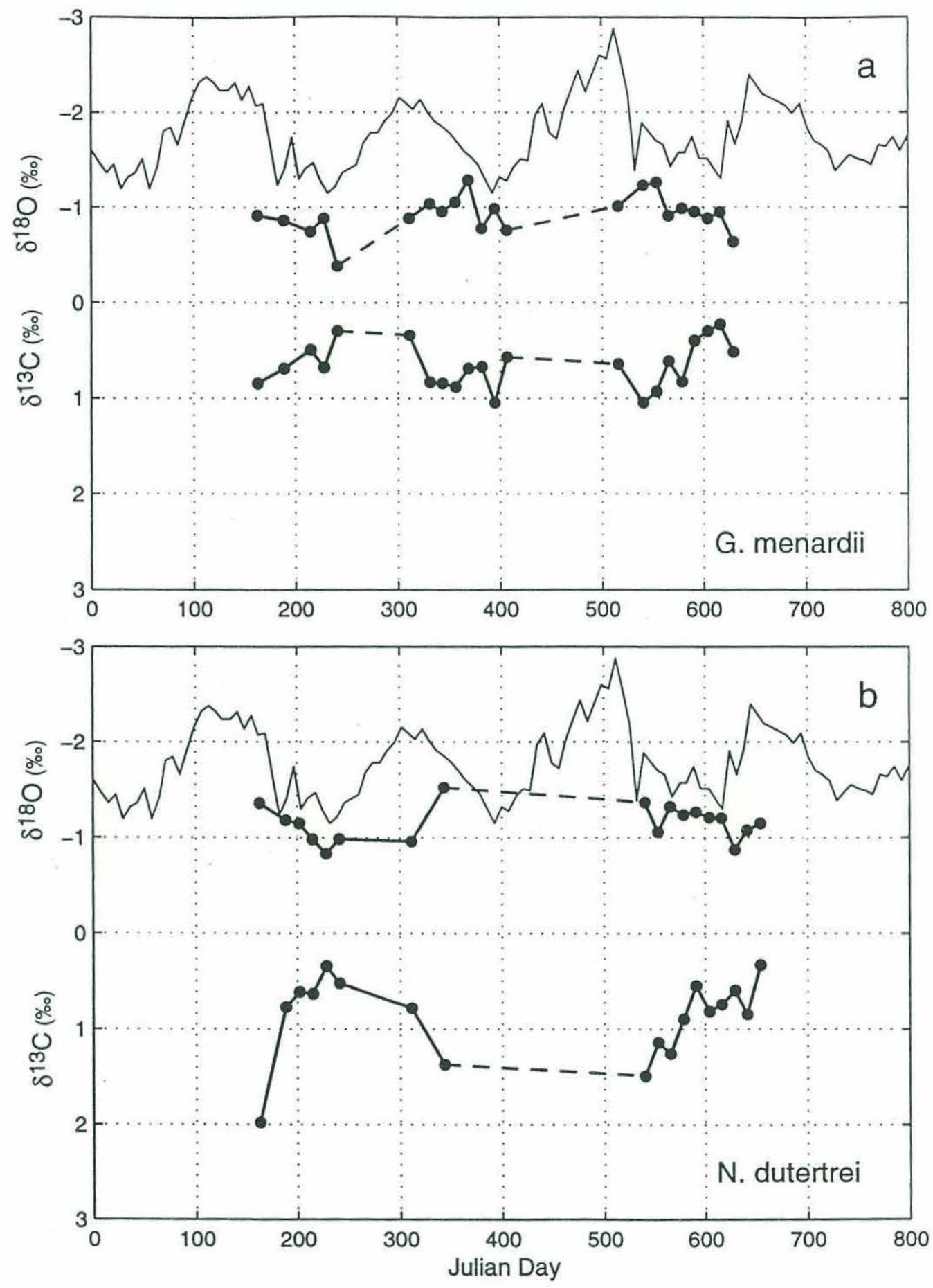

Figure 16 Carbon and oxygen isotopic averages for thermocline species, a) G. menardii and b) $N$. dutertrei, plotted with equilibrium calcite sea surface temperatures $\left(\delta^{18} \mathrm{O}_{\mathrm{c}}\right.$ SSTs). During upwelling, mirror image or opposite isotopic response for $\delta^{13} \mathrm{C}$ and $\delta^{18} \mathrm{O}$ is expected. 

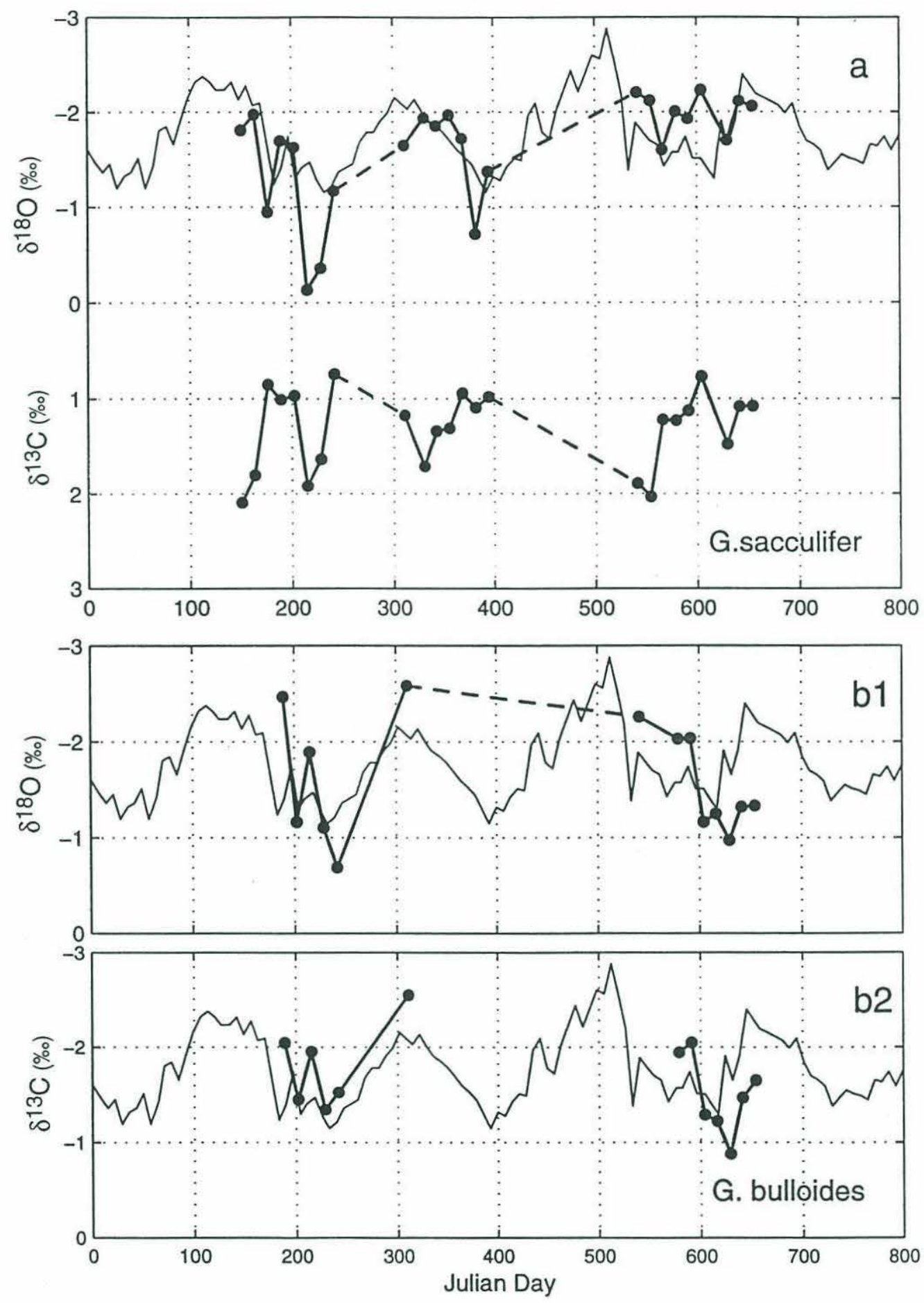

Figure 17 Carbon and oxygen isotopic averages for surface dwellers, a) $G$. sacculifer and b) G. bulloides plotted with equilibrium calcite sea surface temperatures $\left(\delta^{18} \mathrm{O}_{\mathrm{c}}\right.$ SSTs). During upwelling, mirror image or opposite isotopic response is expected, but $G$. bulloides has covarying $\delta^{13} \mathrm{C}$ and $\delta^{18} \mathrm{O}$. b1) is G. bulloides $\delta^{18} \mathrm{O}$, and b2) is G. bulloides $\delta^{13} \mathrm{C}$ signal. 


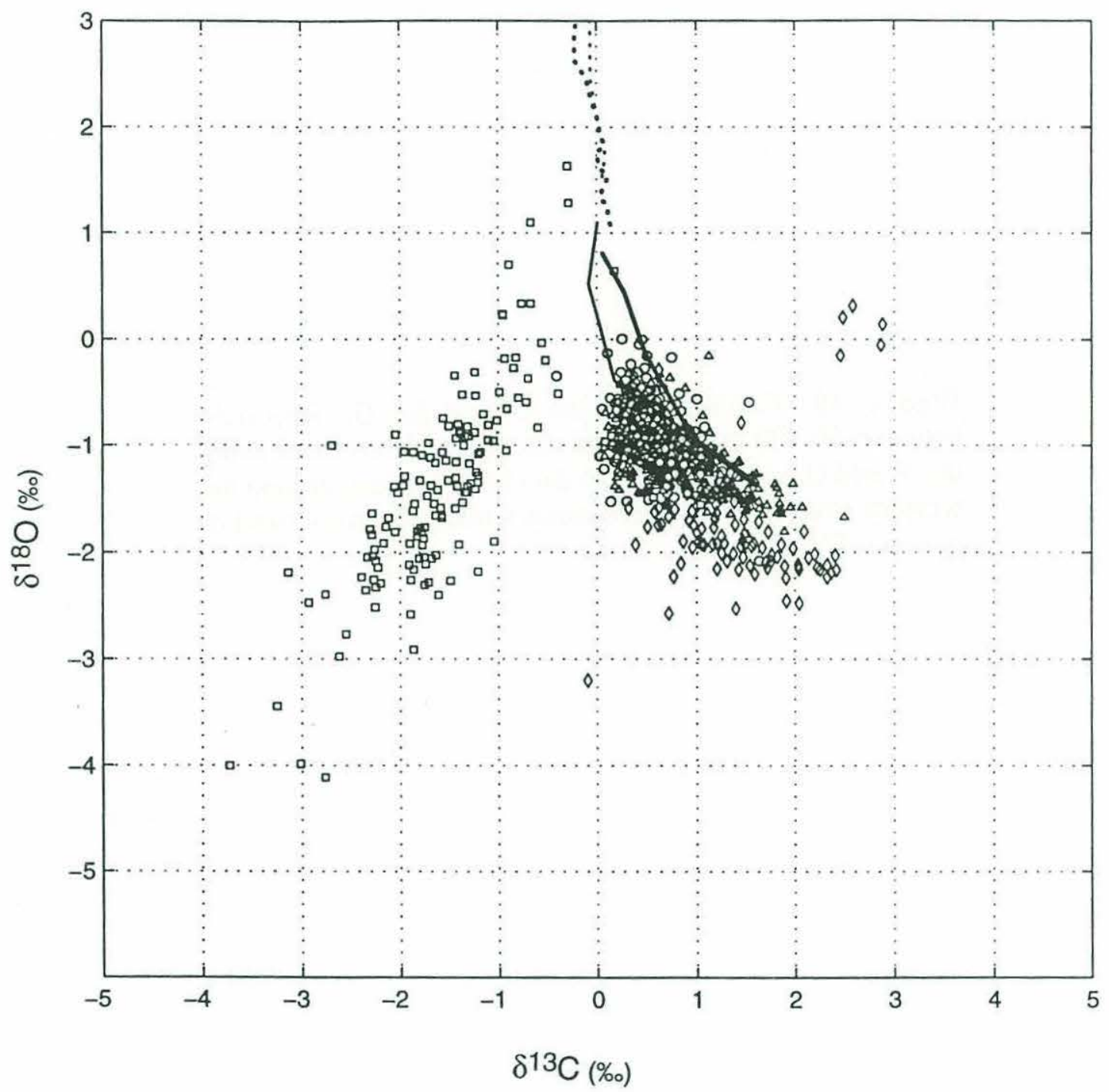

Figure $18 \delta^{13} \mathrm{C}-\delta^{18} \mathrm{O}$ plot of the carbon and oxygen isotopic compositions for all four species plotted with the water column values from GEOSECS Stations 413 (bold line) and 417 (light line). The dotted lines are the water column values below 200 meters depth. G. menardii ( $O$ ), G. sacculifer $(\diamond)$, and $N$. dutertrei $(\Delta)$ all parallel the GEOSECS station data, but $G$. bulloides $(\square)$ varies opposite the water column trend. 
Figure 19 Calculated depth habitat for G. menardii between 50-100 meters depth. Contours determined using the World Ocean Atlas (1994) data for the region around the western Arabian Sea. This species tends to follow a band of constant $\delta^{18} \mathrm{O}$. 
Equilibrium $\delta^{18} \mathrm{O}$ (PDB) G. menardii No Lag

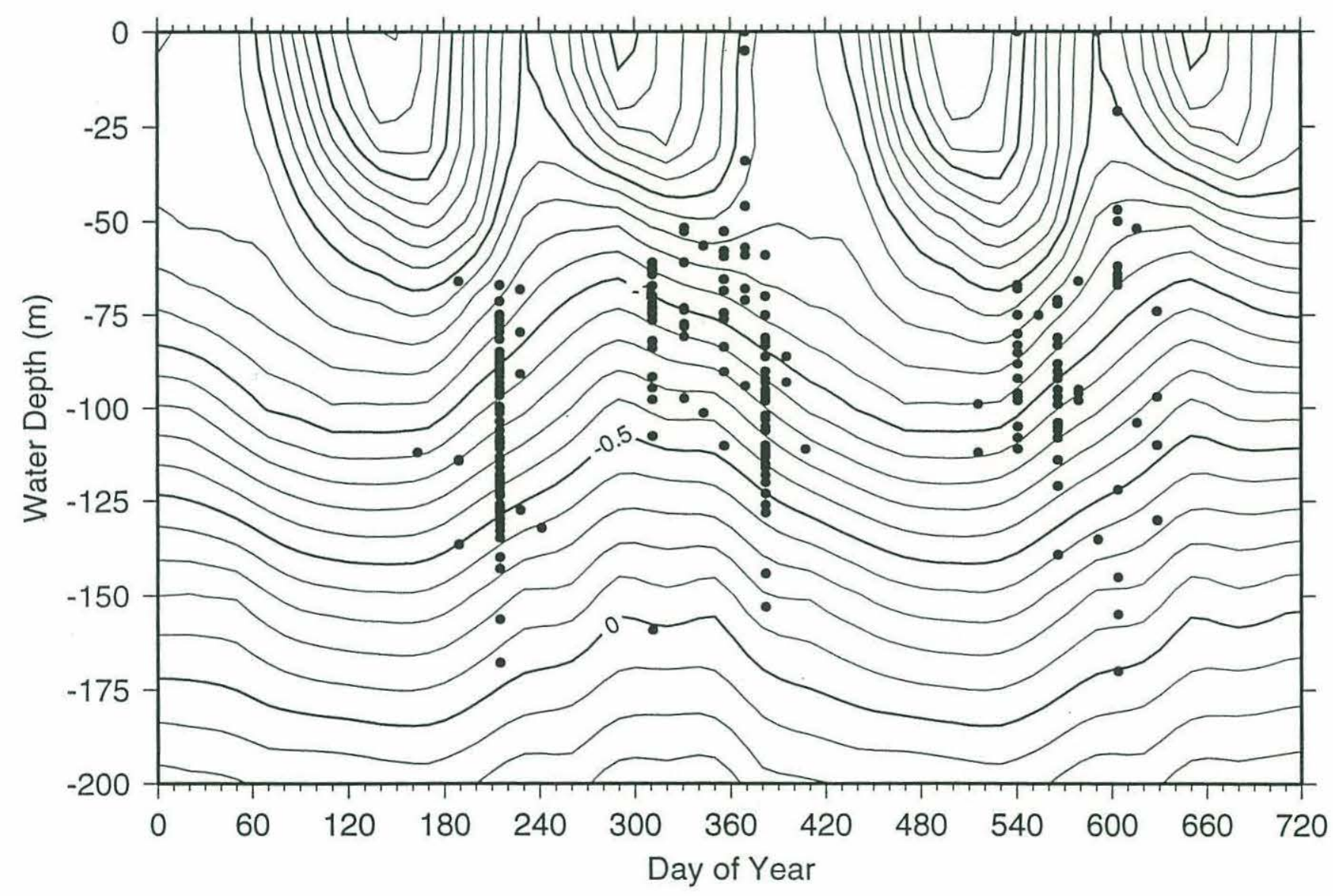


Figure 20 Calculated depth habitat for G. menardii taking into account a 21 day lag. More individuals (than Figure 17) shown to be in the realm of equilibrium calcification within the thermocline. 
Equilibrium $\delta^{18} \mathrm{O}$ (PDB) G. menardii 21 day lag

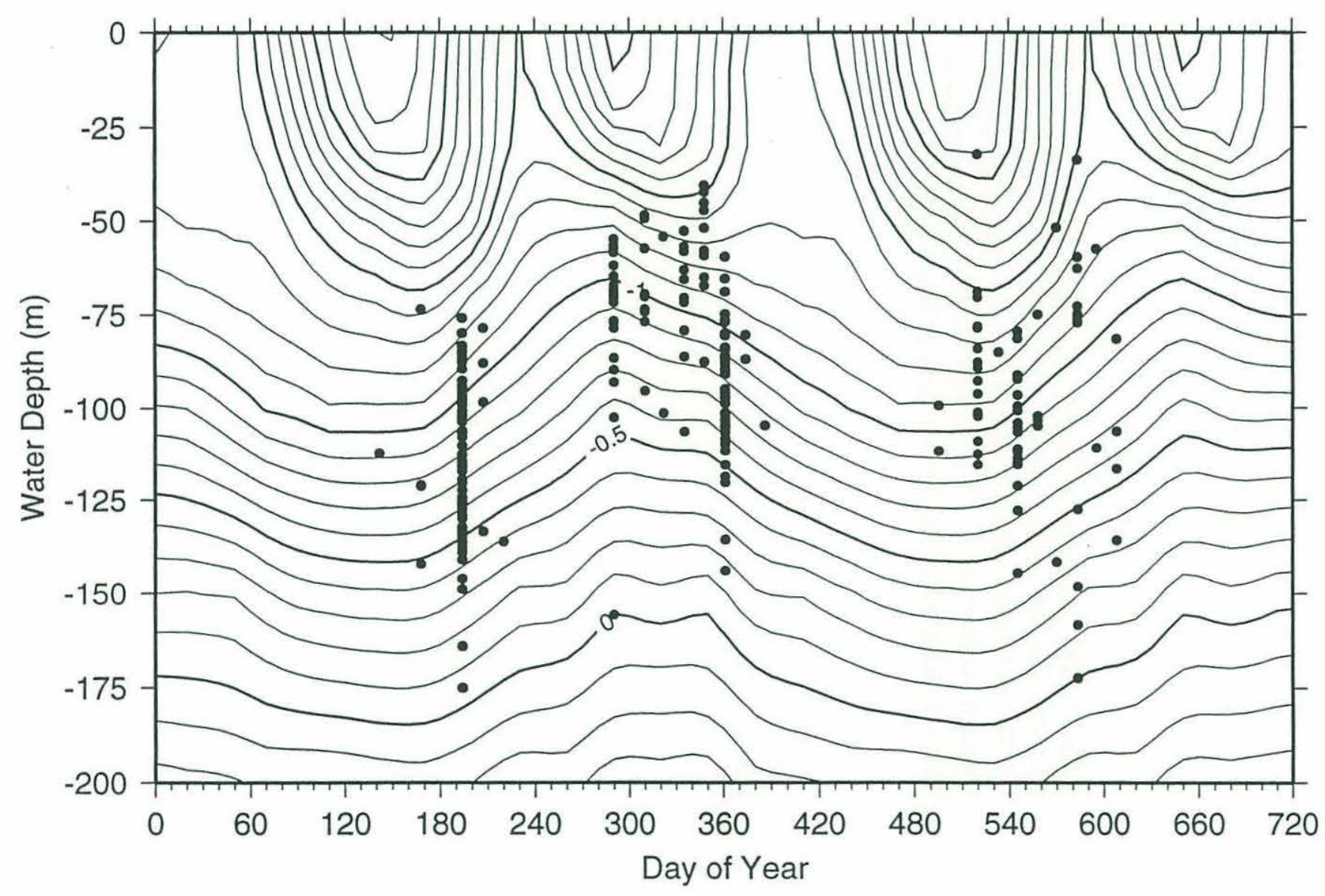


Figure 21 Calculated depth habitat for $N$. dutertrei between 50-100 meters depth. Contours determined using the World Ocean Atlas (1994) data for the region around the western Arabian Sea. This species lives at the thermocline and is unaffected by changes in the surface waters. 
Equilibrium $\delta^{18} \mathrm{O}(\mathrm{PDB}) \mathrm{N}$. dutertrei No Lag

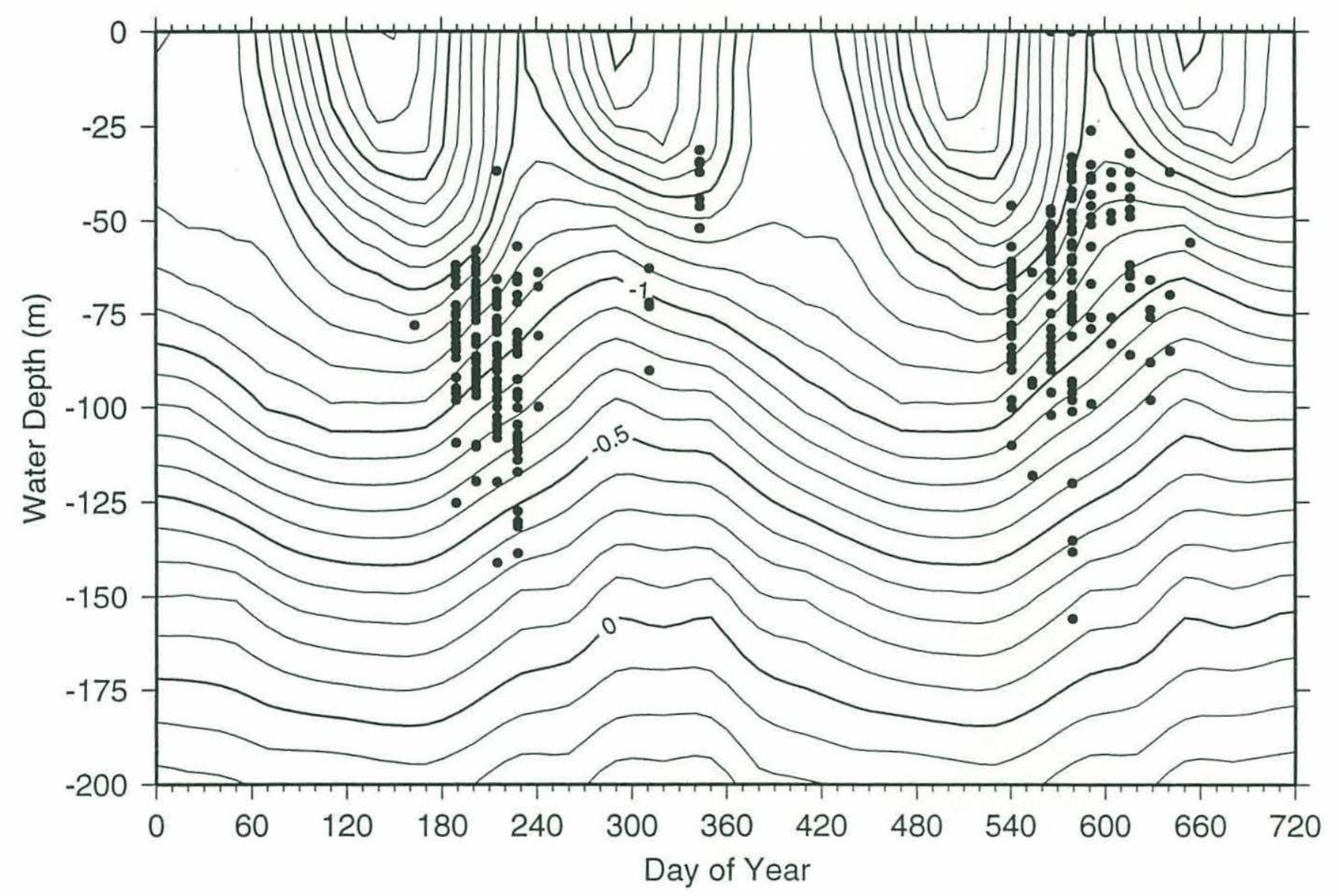


Figure 22 Calculated depth habitat for $N$. dutertrei taking into account a 21 day lag. More individuals (than Figure 19) shown to be in the realm of equilibrium calcification within the thermocline. 
Equilibrium $\delta^{18} \mathrm{O}(\mathrm{PDB}) \mathrm{N}$. dutertrei 21 day lag

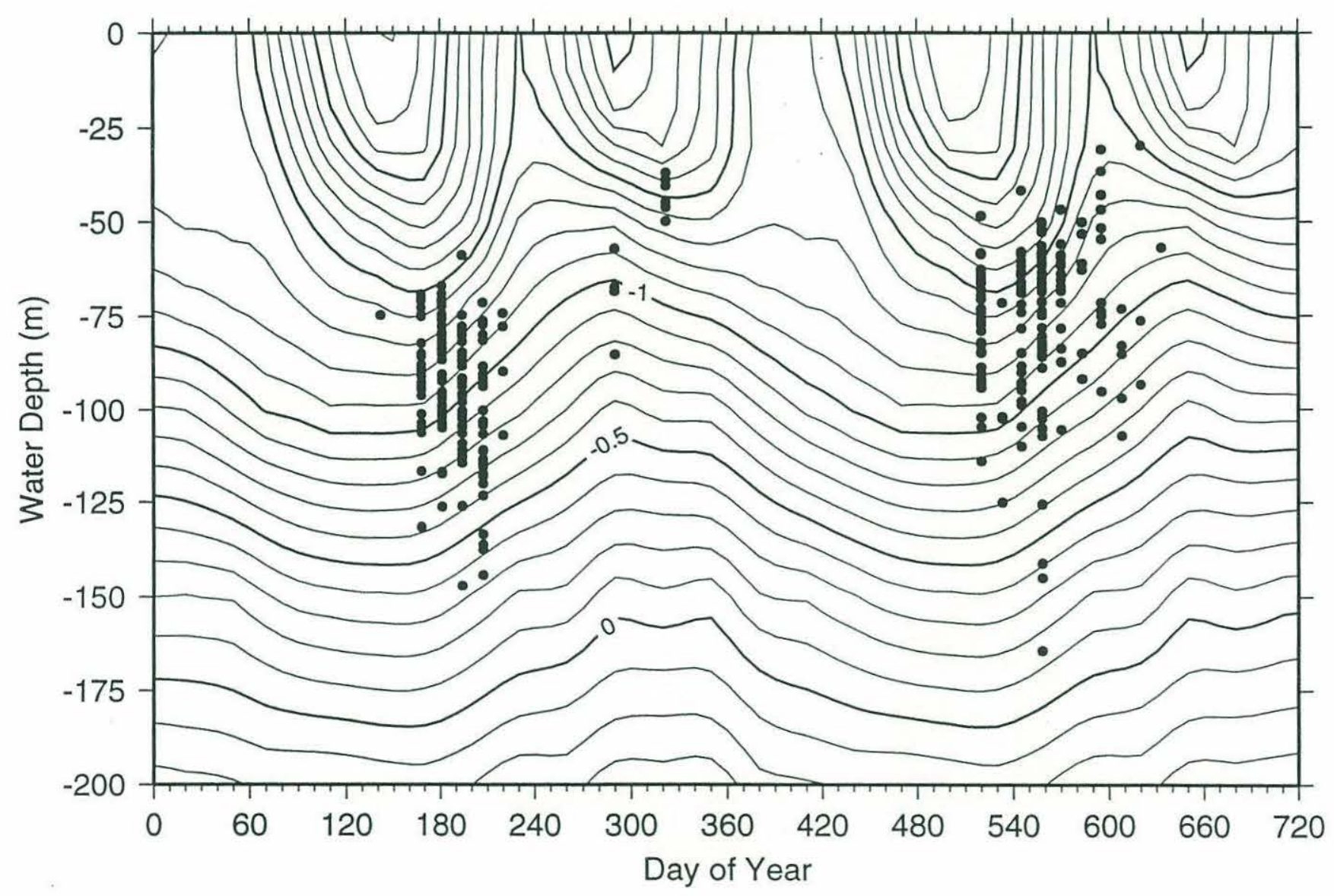


Figure 23 Calculated depth habitat for G. sacculifer. Contours determined using the World Ocean Atlas (1994) data for the region around the western Arabian Sea. Many of the individuals plot at 0 meters depth, indicating disequilibrium. 
Equilibrium $\delta^{18} \mathrm{O}$ (PDB) G. sacculifer No Lag

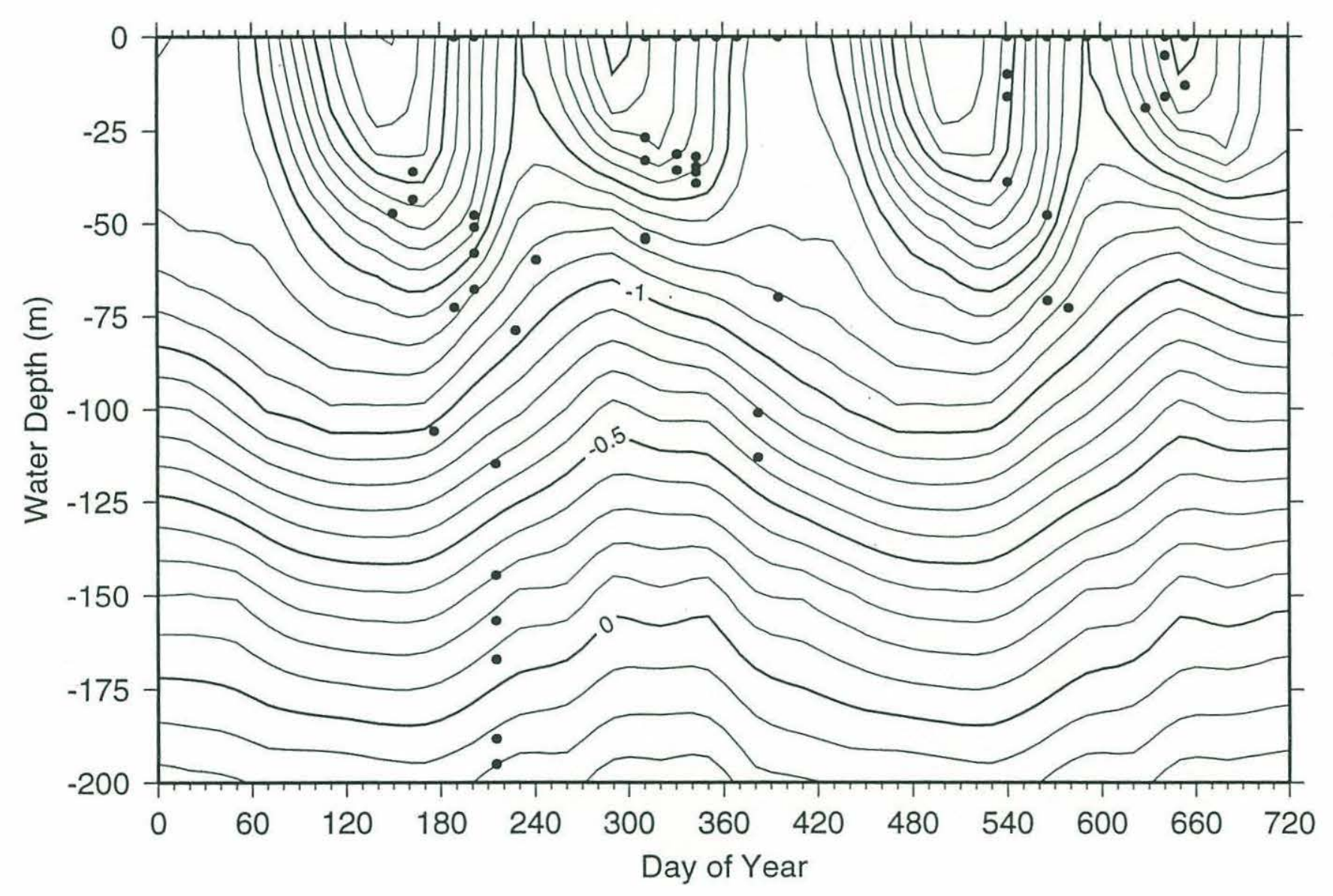


Figure 24 Calculated depth habitat for G. bulloides. Many of the isotopic values are lower than the lowest possible equlibrium values for surface waters (plotted at 0 meters depth), implying that these individuals must be calcifying out of equilibrium. 
Equilibrium $\delta^{18} \mathrm{O}$ (PDB) G. bulloides No Lag

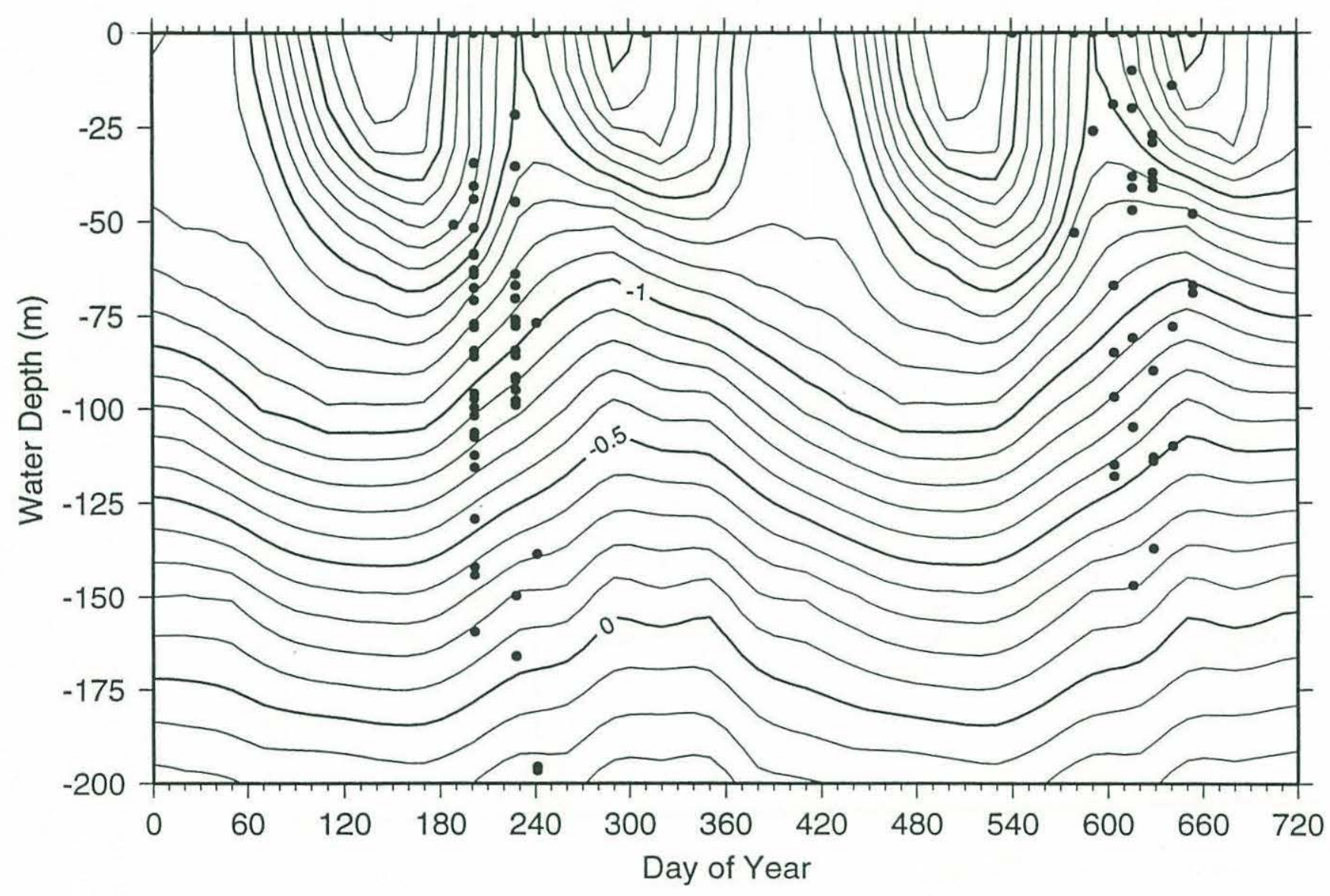



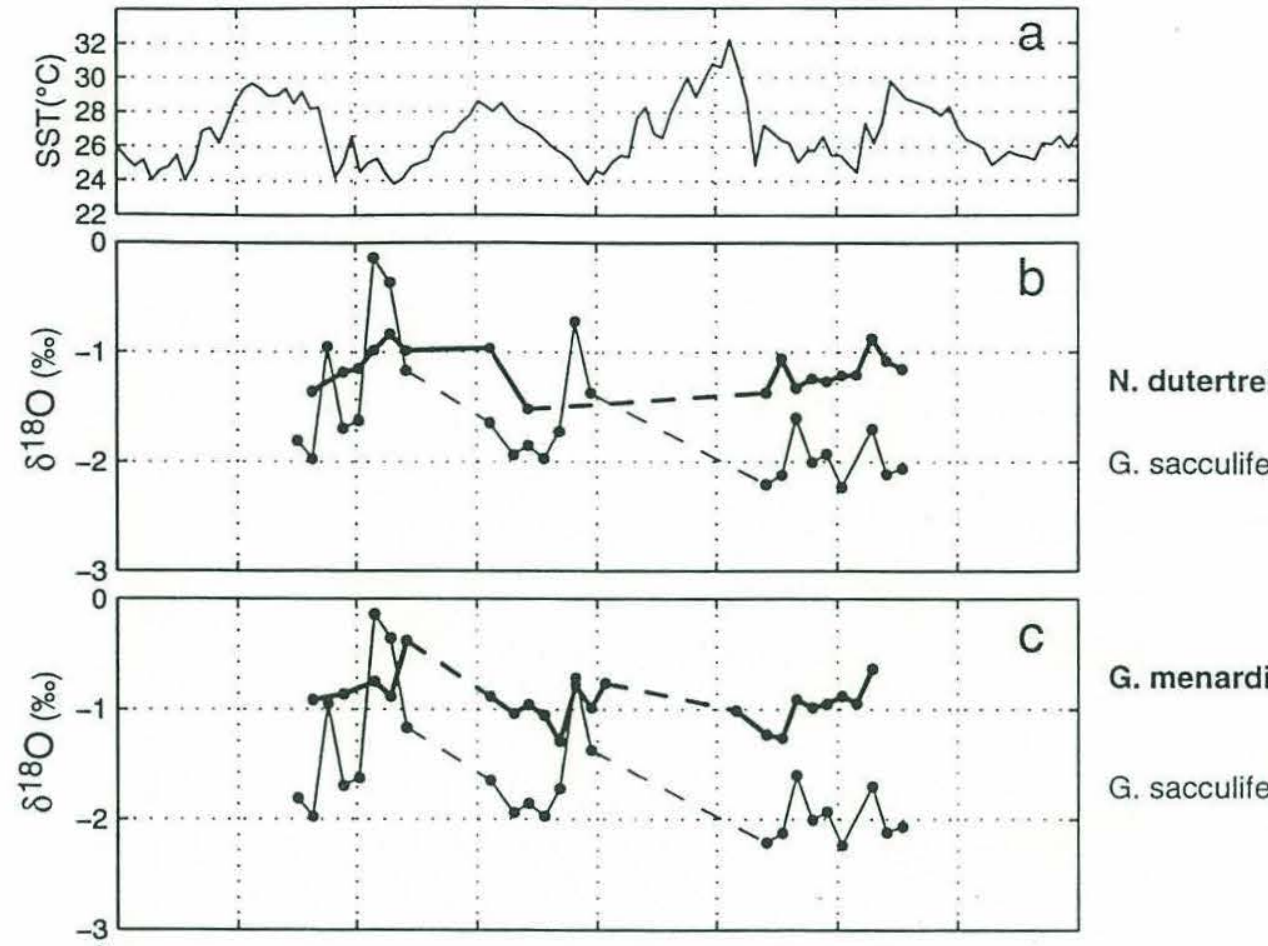

G. menardii

G. sacculifer

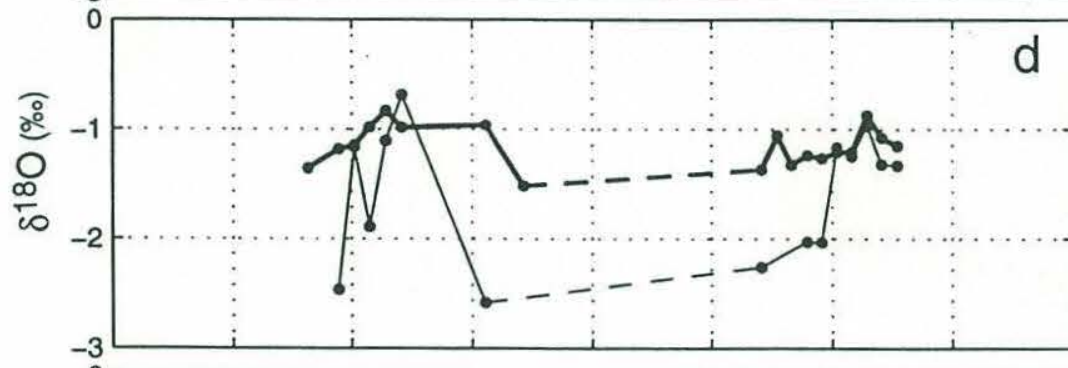

N. dutertrei

G. bulloides

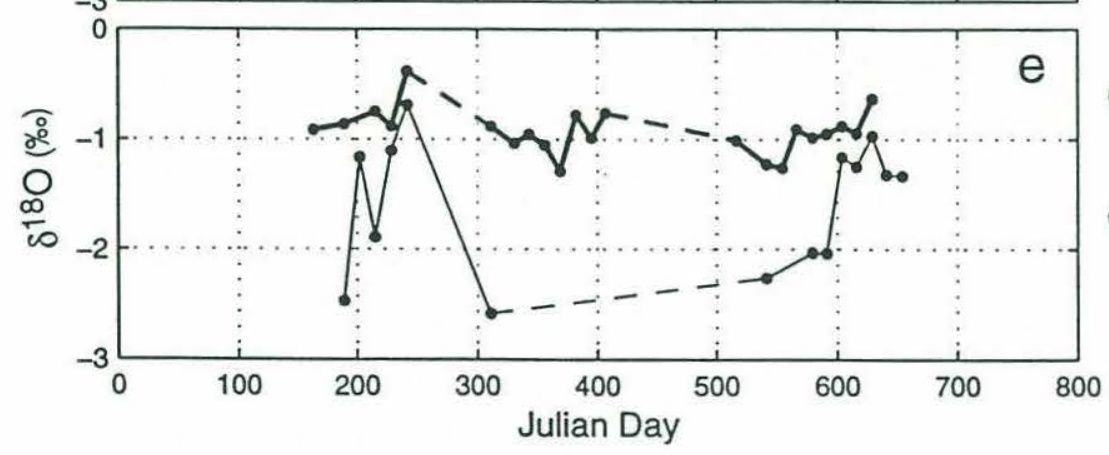

G. menardii

G. bulloides

Figure 25 Difference in oxygen isotopic composition $\left(\Delta \delta^{18} \mathrm{O}\right)$ between surface dwellers (light line) and thermocline dwellers (bold line).

a) AVHRR sea surface temperatures, b) G. sacculifer and N. dutertrei, c) G. sacculifer and G. menardii, d) G. bulloides and N. dutertrei, and e) G. bulloides and G. menardii. During the upwelling periods, the $\Delta \delta^{18} \mathrm{O}$ becomes smaller, indicating that the foraminifera are living and calcifying within the same water. 

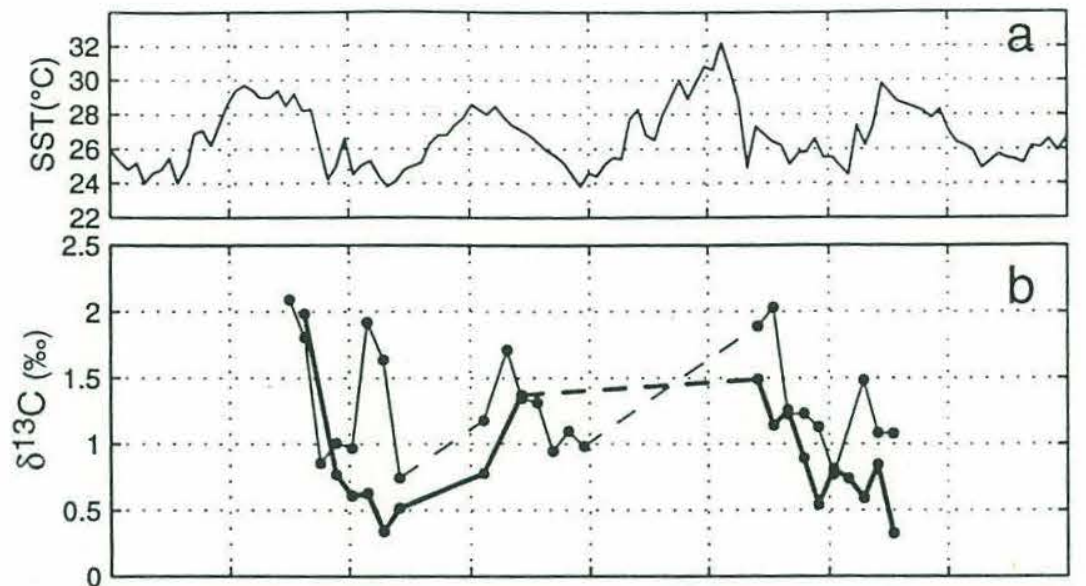

G. sacculifer

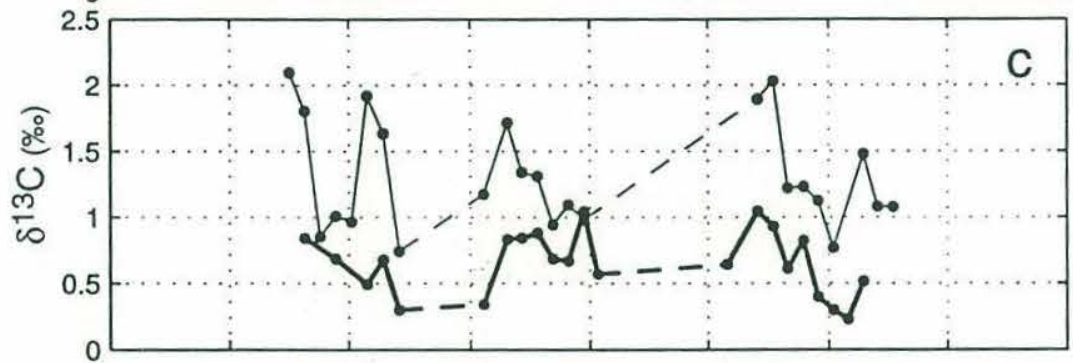

N. dutertrei

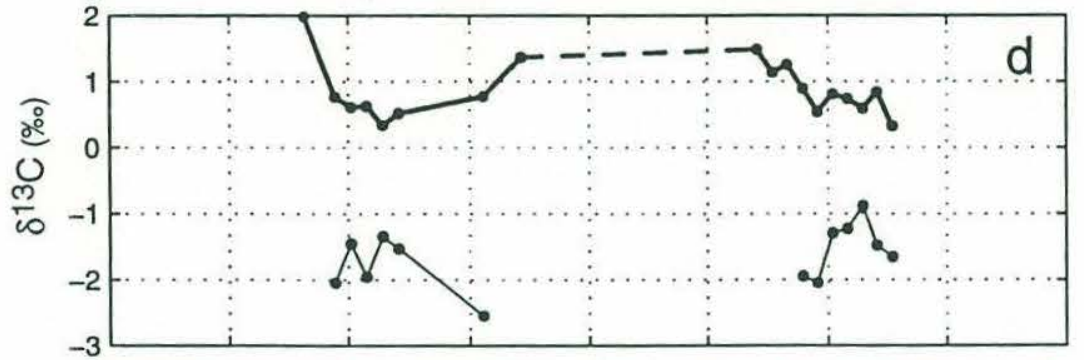

G. sacculifer

G. menardii

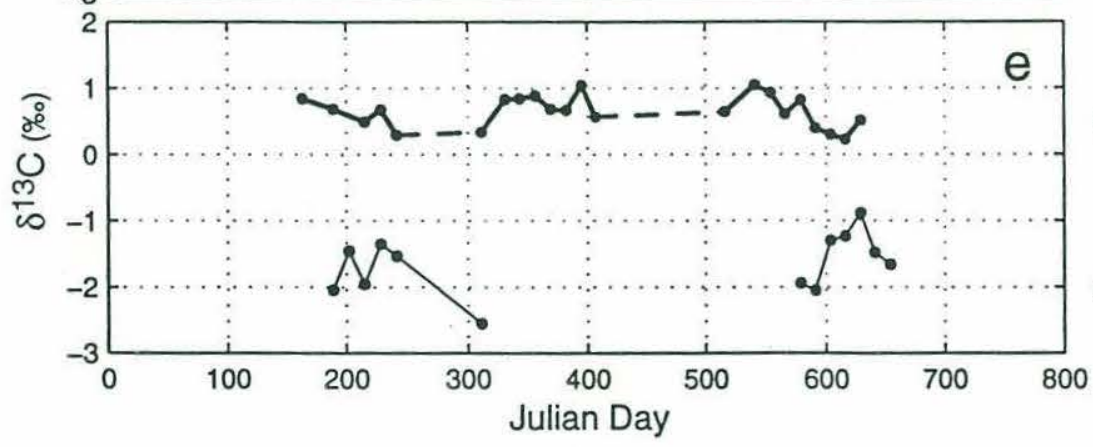

G. bulloides

N. dutertrei

G. menardii

G. bulloides

Figure 26 Difference in carbon isotopic composition $\left(\Delta \delta^{13} \mathrm{C}\right)$ between surface dwellers (light line) and thermocline dwellers (bold line).

a) AVHRR sea surface temperatures, b) G. sacculifer and N. dutertrei,

c) G. sacculifer and G. menardii, d) G. bulloides and N. dutertrei, and

e) G. bulloides and G. menardii. During the upwelling periods, the $\Delta \delta^{13} \mathrm{C}$ becomes smaller, indicating that the foraminifera are living and calcifying within the same water. 
TABLES 


\begin{tabular}{ccccccc} 
Station & $\begin{array}{c}\text { Latitude } \\
\left({ }^{\circ} \mathrm{N}\right)\end{array}$ & $\begin{array}{c}\text { Longitude } \\
\left({ }^{\circ} \mathrm{E}\right)\end{array}$ & $\begin{array}{c}\text { Depth } \\
(\text { meters })\end{array}$ & $\begin{array}{c}\text { Temperature } \\
\left({ }^{\circ} \mathrm{C}\right)\end{array}$ & $\begin{array}{c}\text { Salinity } \\
(\% 0)\end{array}$ & $\begin{array}{c}\delta^{18} \mathbf{O}_{\mathbf{w}} \\
(\% 0)\end{array}$ \\
\hline 416 & 19.76 & 64.62 & 3 & 26.346 & 36.487 & 0.78 \\
416 & 19.76 & 64.62 & 71 & 23.165 & 36.255 & 0.74 \\
416 & 19.76 & 64.62 & 114 & 20.695 & 36.052 & 0.72 \\
416 & 19.76 & 64.62 & 132 & 19.926 & 35.984 & 0.68 \\
416 & 19.76 & 64.62 & 179 & 18.175 & 35.947 & 0.54 \\
416 & 19.76 & 64.62 & 187 & 17.885 & 35.936 & 0.61 \\
428 & -37.76 & 57.63 & 1 & 18.747 & 35.334 & 0.60 \\
428 & -37.76 & 57.63 & 86 & 15.151 & 35.399 & 0.61 \\
435 & -39.95 & 109.97 & 5 & 15.488 & 34.840 & 0.37 \\
435 & -39.95 & 109.97 & 52 & 13.783 & 34.749 & 0.26 \\
435 & -39.95 & 109.97 & 116 & 10.974 & 34.799 & 0.28 \\
438 & -19.49 & 101.29 & 8 & 26.618 & 35.282 & 0.55 \\
438 & -19.49 & 101.29 & 102 & 21.896 & 35.449 & 0.60 \\
446 & 12.52 & 84.51 & 9 & 28.109 & 33.250 & 0.23 \\
446 & 12.52 & 84.51 & 89 & 27.469 & 34.803 & 0.55 \\
446 & 12.52 & 84.51 & 118 & 25.047 & 34.730 & 0.44 \\
446 & 12.52 & 84.51 & 195 & 15.187 & 34.926 & 0.35 \\
450 & -10.01 & 79.99 & 1 & 28.230 & 34.231 & 0.30 \\
450 & -10.01 & 79.99 & 63 & 24.201 & 34.922 & 0.46 \\
450 & -10.01 & 79.99 & 166 & 14.319 & 34.673 & 0.22 \\
& & & & & & \\
\hline & & & & & &
\end{tabular}

Table 1. GEOSECS station data used to find the linear regression (shown in Figure 3) for the $\delta^{18} \mathrm{O}_{\mathrm{w}}$ :salinity relationship for the shallow $(<200 \mathrm{~m})$ Indian Ocean. 


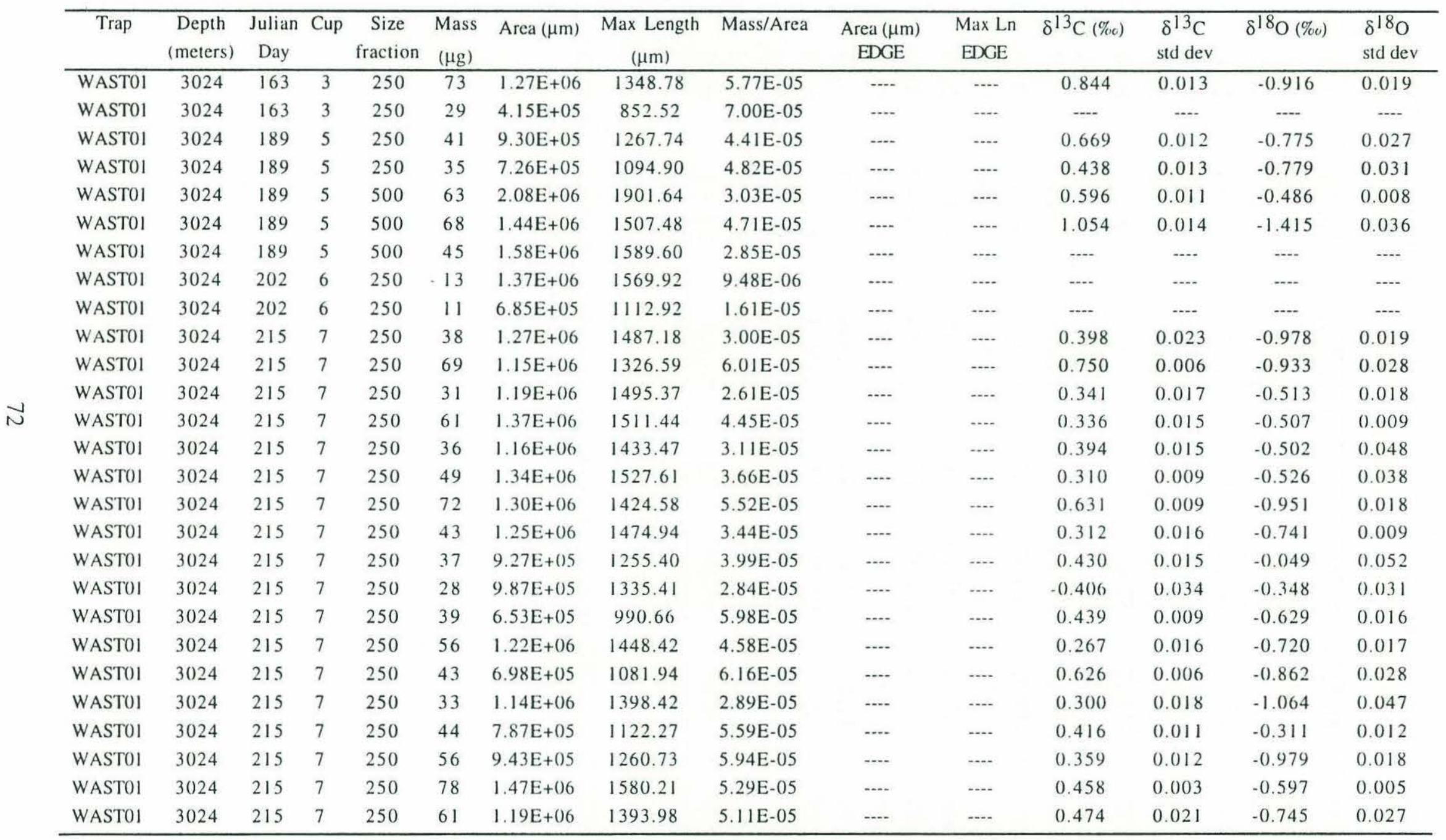

Table 2. Morphometric and isotopic data for Globorotalia menardii from three Western Arabian Sea traps (WAST01, 02, 03) 


\begin{tabular}{|c|c|c|c|c|c|c|c|c|c|c|c|c|c|c|}
\hline Trap & $\begin{array}{c}\text { Depth } \\
\text { (meters) }\end{array}$ & $\begin{array}{c}\text { Julian } \\
\text { Day }\end{array}$ & Cup & $\begin{array}{c}\text { Size } \\
\text { fraction }\end{array}$ & $\begin{array}{l}\text { Mass } \\
(\mu \mathrm{g})\end{array}$ & Area $(\mu \mathrm{m})$ & $\begin{array}{l}\text { Max Length } \\
(\mu \mathrm{m})\end{array}$ & Mass/Area & $\begin{array}{c}\text { Area }(\mu \mathrm{m}) \\
\text { EDGE }\end{array}$ & $\begin{array}{l}\text { Max Ln } \\
\text { EDGE }\end{array}$ & $\delta^{13} \mathrm{C}(\%)$ & $\begin{array}{l}\delta^{13} \mathrm{C} \\
\text { std dev }\end{array}$ & $\delta^{18} \mathrm{O}(\% \mathrm{c})$ & $\begin{array}{l}\delta^{18} \mathrm{O} \\
\text { std dev }\end{array}$ \\
\hline WASTOI & 3024 & 215 & 7 & 250 & 72 & $1.18 \mathrm{E}+06$ & 1450.41 & $6.09 \mathrm{E}-05$ & $\cdots$ & $\cdots$ & 0.729 & 0.016 & -1.099 & 0.025 \\
\hline WAST0I & 3024 & 215 & 7 & 250 & 64 & $1.19 \mathrm{E}+06$ & 1394.98 & $5.39 \mathrm{E}-05$ & $\cdots$. & $\cdots \cdot$ & 0.673 & 0.013 & -1.027 & 0.029 \\
\hline WASTOI & 3024 & 215 & 7 & 250 & 60 & $9.93 \mathrm{E}+(155$ & 1326.79 & $6.04 \mathrm{E}-05$ & $\cdots$. & $\cdots-$ & 0.642 & 0.012 & -0.854 & 0.035 \\
\hline WAST0I & 3024 & 215 & 7 & 250 & 48 & $1.30 \mathrm{E}+06$ & 1475.62 & $3.70 \mathrm{E}-05$ & -... & -..- & 0.137 & 0.014 & -0.557 & 0.012 \\
\hline WASTOI & 3024 & 215 & 7 & 250 & 66 & $1.29 \mathrm{E}+(06$ & 1484.59 & $5.11 \mathrm{E}-05$ & $\cdots$ & $\cdots$ & 0.312 & 0.003 & -0.691 & 0.015 \\
\hline WASTOI & 3024 & 215 & 7 & 250 & 33 & $1.12 \mathrm{E}+06$ & 1391.41 & $2.94 \mathrm{E}-05$ & $\cdots-$. & $\cdots-$. & 0.521 & 0.016 & -0.971 & 0.047 \\
\hline WAST0I & 3024 & 215 & 7 & 250 & 36 & $1.02 \mathrm{E}+06$ & 1381.12 & $3.54 \mathrm{E}-05$ & .... & -... & 0.388 & 0.014 & -0.414 & 0.023 \\
\hline WAST0I & 3024 & 215 & 7 & 250 & 41 & $1.10 \mathrm{E}+(06$ & 1402.54 & $3.74 \mathrm{E}-05$ & $\cdots-$ & $\cdots$ & 0.343 & 0.025 & -0.523 & 0.032 \\
\hline WASTOI & 3024 & 215 & 7 & 250 & 46 & $9.28 \mathrm{E}+(1) 5$ & 1297.32 & $4.96 \mathrm{E}-05$ & …- & $\cdots$ & 0.514 & 0.015 & -0.895 & 0.018 \\
\hline WAST01 & 3024 & 215 & 7 & 250 & 32 & $1.05 \mathrm{E}+(06$ & 1368.34 & 3.06E-05 & -... & $\cdots-$ & 0.292 & 0.014 & -0.476 & 0.044 \\
\hline WASTOI & 3024 & 215 & 7 & 250 & 39 & $8.17 \mathrm{E}+(105$ & 1091.81 & $4.78 \mathrm{E}-05$ & $\cdots$ & … & 0.491 & 0.014 & -1.114 & 0.013 \\
\hline WAST0I & 3024 & 215 & 7 & 250 & 31 & $7.48 \mathrm{E}+05$ & 1140.13 & 4.14E-05 & $\cdots \cdot$ & $\cdots-$ & 0.568 & 0.016 & -1.136 & 0.049 \\
\hline WASTOI & 3024 & 215 & 7 & 250 & 33 & $6.54 \mathrm{E}+(05$ & 1015.05 & $5.04 \mathrm{E}-05$ & $\cdots$. & … & 0.523 & 0.012 & -0.494 & 0.017 \\
\hline WAST01 & 3024 & 215 & 7 & 250 & 46 & $7.46 \mathrm{E}+05$ & 1179.67 & $6.17 \mathrm{E}-05$ & $\cdots \cdot$ & -... & 0.494 & 0.007 & -1.011 & 0.013 \\
\hline WAST0I & 3024 & 215 & 7 & 250 & 46 & $7.69 \mathrm{E}+05$ & 1152.00 & $5.98 \mathrm{E}-05$ & -... & -... & 0.763 & 0.017 & -1.004 & 0.016 \\
\hline WAST01 & 3024 & 215 & 7 & 250 & 38 & $7.92 \mathrm{E}+(05$ & 1160.81 & $4.80 \mathrm{E}-05$ & -... & -..- & 0.294 & 0.016 & -0.858 & 0.034 \\
\hline WAST0I & 3024 & 215 & 7 & 250 & 37 & $5.73 E+05$ & 1008.63 & $6.45 \mathrm{E}-05$ & -... & .... & 0.242 & 0.004 & -0.311 & 0.030 \\
\hline WASTOI & 3024 & 215 & 7 & 250 & 34 & $5.56 \mathrm{E}+05$ & 987.73 & $6.12 \mathrm{E}-05$ & $\cdots$. & -... & 0.348 & 0.018 & -0.439 & 0.046 \\
\hline WAST0I & 3024 & 215 & 7 & 250 & 24 & $6.67 \mathrm{E}+(05$ & 1024.52 & $3.60 \mathrm{E}-05$ & $\cdots$ & $\cdots$ & $\cdots$ & -..- & --.. & --.- \\
\hline WAST0I & 3024 & 215 & 7 & 250 & 25 & $4.36 E+(05$ & 832.48 & $5.74 \mathrm{E}-05$ & $\cdots$ & $\cdots$ & -.- & $\cdots-$ & -.. & $\cdots$ \\
\hline WAST01 & 3024 & 215 & 7 & 250 & 26 & $9.31 \mathrm{E}+05$ & 1278.66 & $2.79 \mathrm{E}-05$ & $\cdots-$ & $\cdots$ & $\cdots$ & $\cdots$ & -..- & $\cdots-$ \\
\hline WAST01 & 3024 & 215 & 7 & 250 & 23 & $5.69 E+05$ & 986.66 & 4.05E-05 & $\cdots$ & $\cdots$ & $-\cdots$ & $\cdots$ & -..- & $\cdots$ \\
\hline WAST01 & 3024 & 215 & 7 & 250 & 23 & $6.15 E+05$ & 1092.02 & $3.74 \mathrm{E}-05$ & -..- & -... & --- & .... & -... & -... \\
\hline WAST0I & 3024 & 215 & 7 & 250 & 16 & $3.87 \mathrm{E}+05$ & 830.87 & 4.13E-05 & $\cdots$ & $\cdots$ & $\cdots$ & -... & -..- & $\cdots$ \\
\hline WAST0I & 3024 & 215 & 7 & 250 & 24 & $7.85 E+05$ & 1132.82 & $3.06 \mathrm{E}-05$ & $\cdots$ & $\cdots \cdot$ & -.-. & $\cdots-$ & $\cdots$ & $\cdots$ \\
\hline WAST0I & 3024 & 215 & 7 & 250 & 25 & $3.18 \mathrm{E}+05$ & 765.42 & 7.87E-05 & $\cdots$. & $\cdots$ & $-\cdots$ & $\cdots$ & -.-. & $\cdots-$ \\
\hline WAST0I & 3024 & 215 & 7 & 250 & 15 & $4.21 \mathrm{E}+05$ & 850.51 & $3.56 \mathrm{E}-05$ & $\cdots$ & $\cdots-$ & $\cdots$ & $\cdots$ & --.- & $\cdots$. \\
\hline
\end{tabular}

Table 2. (cont'd) Morphometric and isotopic data for G. menardii from WAST01 


\begin{tabular}{|c|c|c|c|c|c|c|c|c|c|c|c|c|c|c|}
\hline Trap & $\begin{array}{c}\text { Depth } \\
\text { (meters) }\end{array}$ & $\begin{array}{l}\text { Julian } \\
\text { Day }\end{array}$ & Cup & $\begin{array}{c}\text { Size } \\
\text { fraction }\end{array}$ & $\begin{array}{l}\text { Mass } \\
(\mu \mathrm{g})\end{array}$ & Area $(\mu \mathrm{m})$ & $\begin{array}{c}\text { Max Length } \\
(\mu \mathrm{m})\end{array}$ & Mass/Area & $\begin{array}{c}\text { Area }(\mu \mathrm{m}) \\
\text { EDGE }\end{array}$ & $\begin{array}{l}\text { Max Ln } \\
\text { EDGE }\end{array}$ & $\delta^{13} \mathrm{C}(\% 0)$ & $\begin{array}{l}\delta^{13} \mathrm{C} \\
\text { std dev }\end{array}$ & $\delta^{18} \mathrm{O}(\% \circ)$ & $\begin{array}{l}\delta^{18} \mathrm{O} \\
\text { sid dev }\end{array}$ \\
\hline WAST01 & 3024 & 215 & 7 & 250 & 23 & $9.17 \mathrm{E}+05$ & 1291.47 & $2.51 \mathrm{E}-05$ & $\cdots$ & $\ldots-$ & $\cdots$ & $\cdots$ & $\cdots$ & $\ldots$ \\
\hline WAST01 & 3024 & 215 & 7 & 250 & 25 & $6.38 \mathrm{E}+05$ & 1017.91 & $3.92 \mathrm{E}-05$ & $\ldots$. & $\cdots$ & -.- & $\cdots$ & $-\cdots$ & $\cdots$ \\
\hline WASTOI & 3024 & 215 & 7 & 250 & 17 & $4.67 \mathrm{E}+(05$ & 859.53 & $3.64 \mathrm{E}-05$ & $\ldots$. & $\ldots$. & $\cdots$ & $\cdots$ & $\cdots$ & $\cdots$ \\
\hline WAST0I & 3024 & 215 & 7 & 250 & 22 & $3.04 \mathrm{E}+05$ & 709.62 & $7.25 \mathrm{E}-(05$ & .... & $-\cdots$ & -..- & -... & -... & $-\cdots$ \\
\hline WAST0I & 3024 & 215 & 7 & 500 & 75 & $1.65 \mathrm{E}+06$ & 1734.03 & $4.54 \mathrm{E}-05$ & $\cdots$ & $\ldots$ & 0.375 & 0.013 & -0.913 & 0.025 \\
\hline WAST01 & 3024 & 215 & 7 & 500 & 155 & $2.73 \mathrm{E}+06$ & 2076.52 & $5.69 \mathrm{E}-05$ & $\cdots$ & -... & 0.606 & 0.011 & -0.781 & 0.012 \\
\hline WAST0I & 3024 & 215 & 7 & 500 & 131 & $2.51 \mathrm{E}+06$ & 1959.58 & $5.22 \mathrm{E}-05$ & $\cdots$. & $\cdots$ & 0.774 & 0.003 & -0.963 & 0.010 \\
\hline WAST0I & 3024 & 215 & 7 & 500 & 78 & $1.35 \mathrm{E}+06$ & 1498.80 & $5.77 \mathrm{E}-05$ & $\ldots$. & $\ldots$ & 0.511 & 0.003 & -0.501 & 0.028 \\
\hline WAST()I & 3024 & 215 & 7 & 500 & 111 & $2.06 \mathrm{E}+06$ & 1827.50 & $5.38 \mathrm{E}-05$ & -... & $\cdots$ & 0.804 & 0.007 & -0.990 & 0.017 \\
\hline WASTOI & 3024 & 215 & 7 & 500 & 77 & $1.79 \mathrm{E}+(1) 6$ & 1795.64 & 4.29E-05 & .... & $\cdots$ & (). 544 & 0.013 & -0.475 & 0.011 \\
\hline WAST0I & 3024 & 215 & 7 & 500 & 92 & $1.94 \mathrm{E}+06$ & 1835.25 & $4.75 \mathrm{E}-05$ & $\cdots$ & $\cdots$ & 0.677 & 0.009 & -0.898 & 0.032 \\
\hline WAST0I & 3024 & 215 & 7 & 500 & 76 & $2.10 \mathrm{E}+06$ & 1819.83 & $3.62 \mathrm{E}-05$ & -... & $\cdots$ & 0.349 & 0.012 & -0.842 & 0.025 \\
\hline WAST()I & 3024 & 215 & 7 & 500 & 118 & $1.80 \mathrm{E}+06$ & 1792.01 & $6.54 \mathrm{E}-05$ & .... & $\cdots$ & 0.626 & 0.004 & -0.909 & 0.016 \\
\hline WAST01 & 3024 & 215 & 7 & 500 & 70 & $1.91 \mathrm{E}+06$ & 1802.91 & $3.67 \mathrm{E}-05$ & $\cdots$ & $\cdots$ & 0.391 & 0.017 & -0.780 & 0.015 \\
\hline WAST0I & 3024 & 215 & 7 & 500 & 114 & $2.11 \mathrm{E}+06$ & 1910.57 & $5.40 \mathrm{E}-05$ & .... & -... & 0.613 & 0.008 & -0.691 & 0.015 \\
\hline WASTOI & 3024 & 215 & 7 & 500 & 133 & $2.34 \mathrm{E}+06$ & 2027.60 & $5.68 \mathrm{E}-05$ & $\cdots$ & $\cdots$ & 0.404 & 0.006 & -0.841 & 0.024 \\
\hline WAST01 & 3024 & 215 & 7 & 500 & 137 & $2.66 \mathrm{E}+06$ & 2131.56 & $5.15 \mathrm{E}-05$ & $\cdots$ & $\cdots$ & 0.612 & 0.010 & -0.680 & 0.019 \\
\hline WAST01 & 3024 & 215 & 7 & 500 & 136 & $2.28 \mathrm{E}+06$ & 1948.07 & $5.98 \mathrm{E}-05$ & -... & $\cdots$ & 0.655 & 0.004 & -0.736 & 0.014 \\
\hline WAST01 & 3024 & 215 & 7 & 500 & 158 & $3.03 E+06$ & 2246.36 & 5.21 E-05 & $\cdots$ & .... & 0.562 & 0.005 & -0.756 & 0.023 \\
\hline WAST0I & 3024 & 215 & 7 & 500 & 56 & 1. $33 \mathrm{E}+(06$ & 1489.58 & $4.21 \mathrm{E}-05$ & $\cdots$ & -..- & 0.185 & 0.013 & -0.606 & 0.029 \\
\hline WAST01 & 3024 & 215 & 7 & 500 & 172 & $1.23 E+06$ & 1410.51 & $1.40 \mathrm{E}-04$ & $\cdots$ & $\cdots$ & 1.035 & 0.005 & -1.121 & 0.021 \\
\hline WAST0I & 3024 & 215 & 7 & 500 & 142 & $2.50 \mathrm{E}+06$ & 2060.29 & $5.68 \mathrm{E}-05$ & $\cdots$ & $-\cdots$ & 0.717 & 0.005 & -0.962 & 0.017 \\
\hline WAST()I & 3024 & 215 & 7 & 500 & 126 & $2.26 \mathrm{E}+(06$ & 1902.39 & $5.58 \mathrm{E}-(05$ & $\cdots$ & .... & 0.520 & 0.009 & -0.811 & 0.009 \\
\hline WASTOI & 3024 & 215 & 7 & 500 & 111 & $1.86 \mathrm{E}+06$ & 1718.63 & $5.97 \mathrm{E}-05$ & -... & .... & 0.996 & 0.014 & -1.222 & 0.019 \\
\hline WASTOI & 3024 & 215 & 7 & 500 & 137 & $3.00 E+06$ & 2190.59 & 4.57E-05 & $\cdots$ & $\cdots$ & 0.629 & 0.004 & -0.655 & 0.010 \\
\hline WASTOI & 3024 & 215 & 7 & 500 & 64 & $1.56 \mathrm{E}+06$ & 1528.38 & $4.11 \mathrm{E}-05$ & $\cdots$ & $\cdots$ & 0.281 & 0.019 & -0.556 & 0.033 \\
\hline WASTOI & 3024 & 215 & 7 & 500 & 81 & $1.96 \mathrm{E}+(06$ & 1722.60 & 4.13E-05 & $\cdots-$ & $\cdots$ & 0.579 & 0.003 & -0.628 & 0.020 \\
\hline
\end{tabular}

Table 2. (cont'd) Morphometric and isotopic data for G. menardii from WAST01 


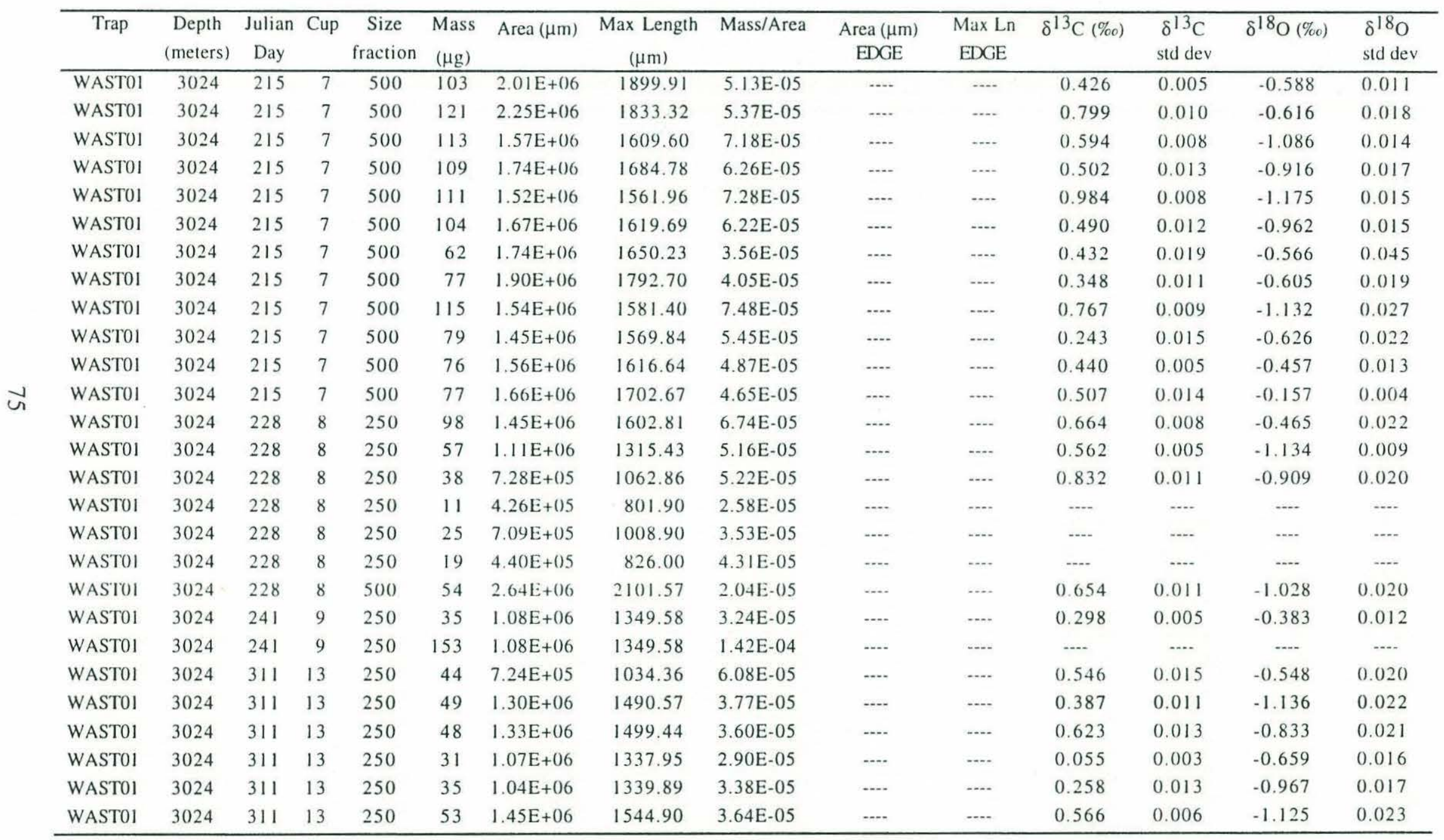

Table 2. (cont'd) Morphometric and isotopic data for G. menardii from WAST01 


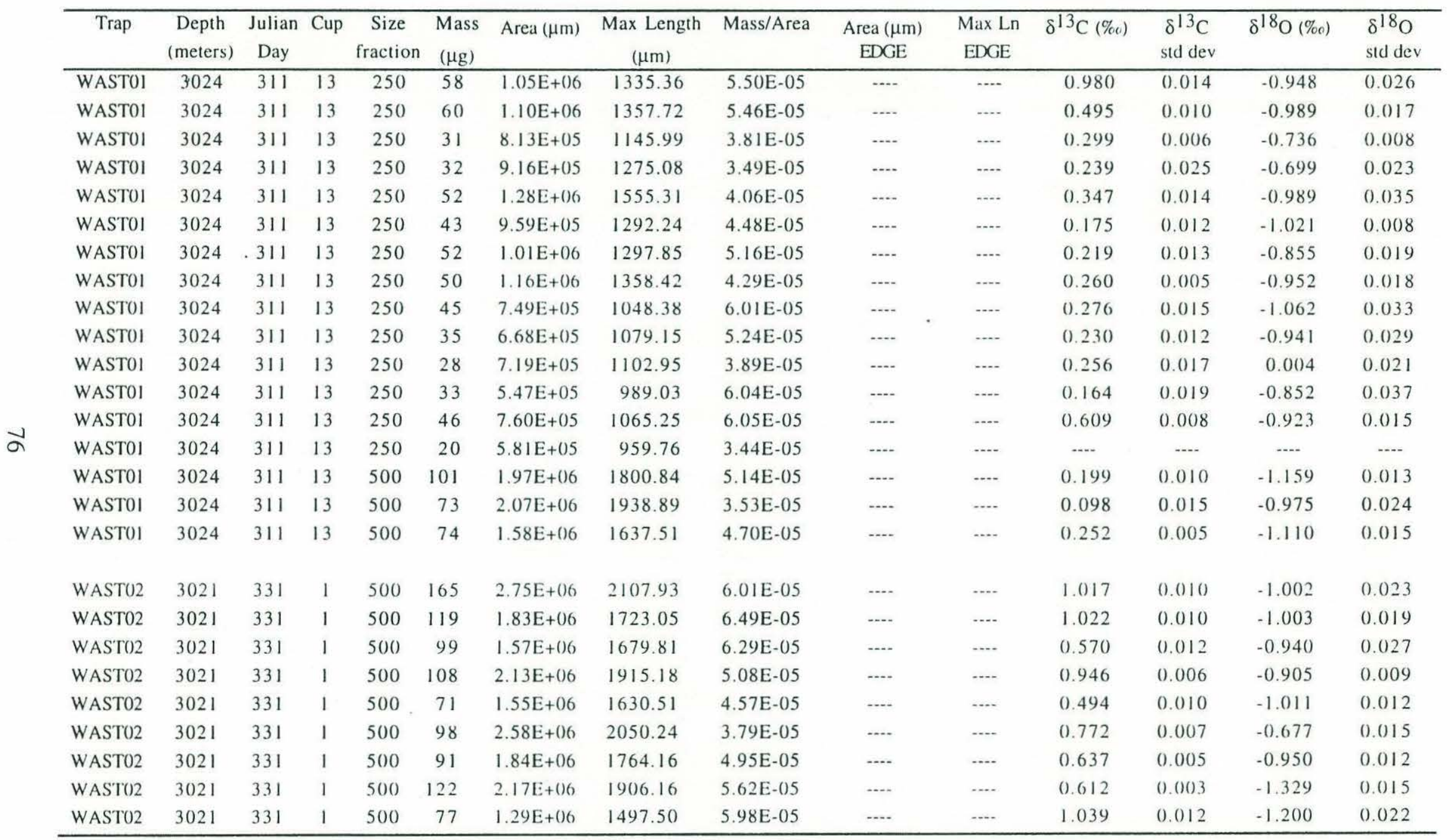

Table 2. (cont'd) Morphometric and isotopic data for G. menardii from WAST01 and WAST02 


\begin{tabular}{|c|c|c|c|c|c|c|c|c|c|c|c|c|c|c|}
\hline Trap & $\begin{array}{c}\text { Depth } \\
\text { (meters) }\end{array}$ & $\begin{array}{c}\text { Julian } \\
\text { Day }\end{array}$ & Cup & $\begin{array}{c}\text { Size } \\
\text { fraction }\end{array}$ & $\begin{array}{l}\text { Mass } \\
(\mu \mathrm{g})\end{array}$ & Area $(\mu \mathrm{m})$ & $\begin{array}{c}\text { Max Length } \\
(\mu \mathrm{m})\end{array}$ & Mass/Area & $\begin{array}{c}\text { Area }(\mu \mathrm{m}) \\
\text { EDGE }\end{array}$ & $\begin{array}{l}\text { Max Ln } \\
\text { EDGE }\end{array}$ & $\delta^{13} \mathrm{C}(\%)$ & $\begin{array}{l}\delta^{13} \mathrm{C} \\
\text { std dev }\end{array}$ & $\delta^{18} \mathrm{O}(\%)$ & $\begin{array}{l}\delta^{18} \mathrm{O} \\
\text { std dev }\end{array}$ \\
\hline WAST02 & 3021 & 331 & 1 & 500 & 51 & $1.33 \mathrm{E}+(06$ & 1494.72 & $3.82 \mathrm{E}-05$ & $\cdots$ & $\cdots$ & 1.226 & 0.006 & -1.346 & 0.013 \\
\hline WAST02 & 3021 & 343 & 2 & 500 & 90 & $1.91 \mathrm{E}+06$ & 1727.89 & $4.72 \mathrm{E}-05$ & .... & & 0.691 & 0.005 & -0.625 & 0.019 \\
\hline WAST02 & 3021 & 343 & 2 & 500 & 81 & $1.73 \mathrm{E}+(06$ & 1689.36 & $4.68 \mathrm{E}-05$ & $\cdots$. & -... & 0.998 & 0.009 & -1.288 & 0.022 \\
\hline WAST02 & 3021 & 356 & 3 & 500 & 137 & $1.20 \mathrm{E}+(06$ & 1423.10 & $1.15 \mathrm{E}-(04$ & -... & -... & 0.524 & 0.006 & -1.331 & 0.019 \\
\hline WASTO2 & 3021 & 356 & 3 & 500 & 166 & $9.49 \mathrm{E}+(1) 5$ & 1290.50 & $1.75 \mathrm{E}-() 4$ & .... & .... & 1.066 & 0.010 & -1.131 & 0.015 \\
\hline WAST02 & 3021 & 356 & 3 & 500 & 168 & $9.42 \mathrm{E}+(05$ & 1228.15 & $1.78 \mathrm{E}-04$ & .... & .... & 1.122 & 0.003 & -1.169 & 0.012 \\
\hline WAST02 & 3021 & 356 & 3 & 500 & 179 & $9.28 \mathrm{E}+0.5$ & 1328.36 & $1.93 \mathrm{E}-04$ & $\cdots$ & -... & 1.250 & 0.006 & -1.246 & 0.025 \\
\hline WASTO2 & 3021 & 356 & 3 & 500 & 49 & $1.56 \mathrm{E}+(06$ & 1619.39 & $3.15 \mathrm{E}-(1) 5$ & $\cdots$. & $\cdots$. & 0.711 & 0.008 & -1.053 & (0.0)22 \\
\hline WAST02 & 3021 & 356 & 3 & 500 & 147 & $2.55 \mathrm{E}+(1) 6$ & 2186.10 & $5.78 \mathrm{E}-05$ & .... & .... & 1.003 & 0.013 & -0.566 & (). 024 \\
\hline WASTO2 & 3021 & 356 & 3 & 500 & 44 & $1.33 E+06$ & 1464.48 & $3.30 \mathrm{E}-05$ & $\cdots$. & $\cdots$ & 0.384 & 0.008 & -1.033 & 0.018 \\
\hline WAST02 & 3021 & 356 & 3 & 500 & 146 & $2.38 \mathrm{E}+06$ & 2009.10 & $6.14 \mathrm{E}-05$ & $\cdots \cdot$ & $\cdots$ & 1.043 & 0.008 & -0.924 & 0.012 \\
\hline WAST02 & 3021 & 356 & 3 & 500 & 103 & $1.88 \mathrm{E}+06$ & 1764.53 & $5.49 \mathrm{E}-05$ & $\cdots$ & -.- & 1.080 & 0.007 & -0.829 & 0.027 \\
\hline WAST02 & 3021 & 356 & 3 & 500 & 124 & $1.33 \mathrm{E}+(06$ & 1432.64 & $9.34 \mathrm{E}-05$ & -..- & $\cdots$. & 0.646 & 0.006 & -1.265 & 0.011 \\
\hline WAST02 & 3021 & 369 & 4 & 250 & 36 & $8.95 E+0.5$ & 1220.39 & 4.02E-05 & $1.27 \mathrm{E}+05$ & 756.97 & 0.446 & 0.011 & -1.161 & 0.020 \\
\hline WAST02 & 3021 & 369 & 4 & 250 & 71 & $1.12 \mathrm{E}+06$ & 1326.94 & $6.34 \mathrm{E}-05$ & $1.64 \mathrm{E}+05$ & 800.55 & 0.907 & 0.003 & -1.249 & 0.005 \\
\hline WAST02 & 3021 & 369 & 4 & 250 & 46 & $1.10 \mathrm{E}+06$ & 1327.93 & $4.18 \mathrm{E}-05$ & $1.68 \mathrm{E}+05$ & 818.19 & 0.637 & 0.018 & -0.823 & 0.009 \\
\hline WAST02 & 3021 & 369 & 4 & 250 & 57 & $1.05 \mathrm{E}+06$ & 1278.49 & $5.43 \mathrm{E}-05$ & $1.49 \mathrm{E}+05$ & 776.93 & 0.775 & 0.012 & -1.488 & 0.009 \\
\hline WAST02 & 3021 & 369 & 4 & 250 & 41 & $8.80 \mathrm{E}+(05$ & 1166.80 & $4.66 \mathrm{E}-05$ & $1.22 \mathrm{E}+05$ & 722.36 & 0.522 & 0.015 & -1.510 & 0.037 \\
\hline WAST02 & 3021 & 369 & 4 & 250 & 52 & $9.84 \mathrm{E}+(1) 5$ & 1208.53 & $5.29 \mathrm{E}-05$ & $1.49 \mathrm{E}+(05$ & 703.51 & 0.597 & 0.016 & -1.361 & 0.015 \\
\hline WAST02 & 3021 & 369 & 4 & 250 & 56 & $1.17 \mathrm{E}+06$ & 1334.80 & 4.79E-05 & $1.64 \mathrm{E}+(05$ & 835.36 & 0.846 & 0.010 & -1.269 & 0.019 \\
\hline WAST02 & 3021 & 369 & 4 & 250 & 26 & $5.36 \mathrm{E}+05$ & 912.36 & $4.85 \mathrm{E}-05$ & $9.13 \mathrm{E}+04$ & 522.82 & 0.711 & 0.019 & -1.451 & 0.008 \\
\hline WAST02 & 3021 & 369 & 4 & 500 & 97 & $9.89 \mathrm{E}+05$ & 1304.38 & $9.81 \mathrm{E}-05$ & $3.57 \mathrm{E}+05$ & 1283.29 & (0. 497 & 0.009 & -1.127 & 0.012 \\
\hline WASTO2 & 3021 & 369 & 4 & 500 & 115 & $7.23 E+(05$ & 1081.95 & $1.59 \mathrm{E}-04$ & $2.51 \mathrm{E}+05$ & 1076.76 & 0.923 & 0.004 & -1.426 & 0.019 \\
\hline WAST02 & 3021 & 382 & 5 & 250 & 49 & $1.08 \mathrm{E}+06$ & 1349.10 & $4.54 \mathrm{E}-05$ & $1.80 \mathrm{E}+05$ & 858.89 & 0.829 & 0.014 & -0.515 & 0.021 \\
\hline WAST02 & 3021 & 382 & 5 & 250 & 61 & $1.14 \mathrm{E}+06$ & 1299.96 & $5.35 \mathrm{E}-05$ & $1.64 \mathrm{E}+05$ & 819.39 & 0.755 & 0.006 & -1.131 & 0.014 \\
\hline WAST02 & 3021 & 382 & 5 & 250 & 67 & $1.22 \mathrm{E}+06$ & 1354.57 & $5.49 \mathrm{E}-05$ & $1.78 \mathrm{E}+05$ & 834.96 & 0.887 & 0.011 & -1.038 & 0.019 \\
\hline WAST02 & 3021 & 382 & 5 & 250 & 14 & $5.87 \mathrm{E}+05$ & 1015.23 & $2.39 \mathrm{E}-05$ & $8.34 \mathrm{E}+04$ & 616.70 & 0.307 & 0.021 & -0.477 & 0.040 \\
\hline
\end{tabular}

Table 2. (cont'd) Morphometric and isotopic data for G. menardii from WAST02 


\begin{tabular}{|c|c|c|c|c|c|c|c|c|c|c|c|c|c|c|}
\hline Trap & $\begin{array}{c}\text { Depth } \\
\text { (meters) }\end{array}$ & $\begin{array}{c}\text { Julian } \\
\text { Day }\end{array}$ & Cup & $\begin{array}{c}\text { Size } \\
\text { fraction }\end{array}$ & $\begin{array}{l}\text { Mass } \\
(\mu g)\end{array}$ & Area $(\mu \mathrm{m})$ & $\begin{array}{l}\text { Max Length } \\
(\mu \mathrm{m})\end{array}$ & Mass/Area & $\begin{array}{c}\text { Area }(\mu \mathrm{m}) \\
\text { EDGE }\end{array}$ & $\begin{array}{l}\text { Max Ln } \\
\text { EDGE }\end{array}$ & $\delta^{13} \mathrm{C}(\% c)$ & $\begin{array}{c}\delta^{13} \mathrm{C} \\
\text { std dev }\end{array}$ & $\delta^{18} \mathrm{O}(\%)$ & $\begin{array}{l}\delta^{18} \mathrm{O} \\
\text { sid dev }\end{array}$ \\
\hline WAST02 & 3021 & 382 & 5 & 250 & 56 & $1.11 \mathrm{E}+06$ & 1471.94 & $5.05 E-05$ & $2.06 E+05$ & 841.05 & 0.887 & 0.004 & -0.887 & 0.023 \\
\hline WAST02 & 3021 & 382 & 5 & 250 & 49 & $1.02 \mathrm{E}+06$ & 1301.97 & $4.80 \mathrm{E}-05$ & $1.46 \mathrm{E}+05$ & 779.17 & 0.687 & 0.018 & -0.843 & 0.014 \\
\hline WAST02 & 3021 & 382 & 5 & 250 & 53 & $1.07 \mathrm{E}+(16$ & 1317.98 & $4.95 \mathrm{E}-05$ & $1.67 \mathrm{E}+05$ & 839.18 & 0.803 & 0.010 & -0.932 & 0.007 \\
\hline WASTO2 & 3021 & 382 & 5 & 250 & 28 & $7.34 \mathrm{E}+05$ & 1053.03 & $3.81 \mathrm{E}-05$ & $1.10 \mathrm{E}+05$ & 650.02 & 0.611 & 0.007 & -0.649 & 0.021 \\
\hline WAST02 & 3021 & 382 & 5 & 250 & 39 & $9.77 E+05$ & 1232.52 & $3.99 \mathrm{E}-05$ & $1.45 E+05$ & 739.99 & 0.408 & 0.009 & -0.638 & 0.016 \\
\hline WAST02 & 3021 & 382 & 5 & 250 & 45 & $1.12 \mathrm{E}+06$ & 1381.75 & $4.02 \mathrm{E}-05$ & $1.64 \mathrm{E}+05$ & 803.67 & 0.570 & 0.010 & -0.684 & 0.024 \\
\hline WAST02 & 3021 & 382 & 5 & 250 & 21 & $8.43 E+05$ & 1132.57 & $2.49 \mathrm{E}-05$ & $1.21 \mathrm{E}+05$ & 712.73 & 0.459 & 0.010 & -0.664 & 0.022 \\
\hline WAST02 & 3021 & 382 & 5 & 250 & 9 & $5.01 E+05$ & 882.18 & $1.80 \mathrm{E}-05$ & $8.89 E+04$ & 550.48 & 0.493 & 0.024 & -0.601 & 0.031 \\
\hline WAST02 & 3() 21 & 382 & 5 & 250 & 11 & $6.47 \mathrm{E}+(15$ & 1007.63 & $1.70 \mathrm{E}-(05$ & $1.02 \mathrm{E}+0.5$ & 670.46 & 1.078 & (0.0)26 & -1.058 & 0.013 \\
\hline WAST02 & 3021 & 382 & 5 & 250 & 35 & $1.14 \mathrm{E}+06$ & 1389.91 & $3.07 \mathrm{E}-05$ & $1.51 \mathrm{E}+05$ & 830.90 & 0.456 & 0.015 & -0.717 & 0.023 \\
\hline WAST02 & 3021 & 382 & 5 & 250 & 39 & $9.81 \mathrm{E}+05$ & 1218.67 & 3.97E-05 & $1.27 E+(05$ & 690.67 & 0.797 & 0.008 & -0.901 & 0.011 \\
\hline WAST02 & 3021 & 382 & 5 & 250 & 11 & $6.47 E+05$ & 1037.63 & $1.70 \mathrm{E}-05$ & $1.05 E+05$ & 649.57 & 0.218 & 0.016 & -0.560 & 0.018 \\
\hline WAST02 & 3021 & 382 & 5 & 250 & 9 & $6.38 E+05$ & 1036.16 & $1.41 \mathrm{E}-05$ & $9.57 \mathrm{E}+04$ & 6.33 .13 & 0.271 & 0.019 & -0.741 & 0.050 \\
\hline WAST02 & 3021 & 382 & 5 & 250 & 41 & $5.45 E+05$ & 894.50 & $7.52 \mathrm{E}-05$ & $7.94 \mathrm{E}+04$ & 571.31 & 0.482 & 0.019 & -0.273 & 0.025 \\
\hline WAST02 & 3021 & 382 & 5 & 250 & 44 & $1.13 \mathrm{E}+06$ & 1463.55 & $3.89 \mathrm{E}-05$ & $1.56 \mathrm{E}+05$ & 907.05 & 0.687 & 0.010 & -1.030 & 0.017 \\
\hline WASTO2 & 3021 & 382 & 5 & 250 & 35 & -... & -... & -..- & $1.60 \mathrm{E}+05$ & 758.61 & 1.530 & 0.021 & -0.598 & 0.036 \\
\hline WAST02 & 3021 & 382 & 5 & 250 & 32 & $5.58 E+05$ & 924.57 & $5.73 \mathrm{E}-05$ & $8.40 E+04$ & $6(15.33$ & 0.468 & 0.058 & -0.891 & 0.092 \\
\hline WAST02 & 3021 & 382 & 5 & 250 & 32 & $5.39 E+05$ & 955.81 & $5.94 \mathrm{E}-05$ & $9.13 E+04$ & 621.47 & 0.623 & 0.216 & -1.245 & 0.089 \\
\hline WAST02 & 3021 & 382 & 5 & 500 & 76 & $7.89 E+05$ & 1125.38 & $9.63 \mathrm{E}-05$ & $2.81 \mathrm{E}+05$ & 1125.25 & 0.573 & 0.015 & -0.621 & 0.022 \\
\hline WAST02 & 3021 & 382 & 5 & 500 & 131 & $8.62 E+05$ & 1182.13 & 1.52E-04 & $2.51 \mathrm{E}+05$ & 1068.90 & (0.849 & 0.006 & -0.926 & 0.008 \\
\hline WAST02 & 3021 & 382 & 5 & 500 & 110 & $7.80 \mathrm{E}+05$ & 1059.43 & $1.41 \mathrm{E}-04$ & $3.08 \mathrm{E}+05$ & 1193.87 & 0.651 & 0.007 & -0.759 & 0.008 \\
\hline WAST02 & 3021 & 382 & 5 & 500 & 115 & $8.26 \mathrm{E}+05$ & 1121.11 & $1.39 \mathrm{E}-04$ & $2.91 \mathrm{E}+05$ & 1110.36 & 0.672 & 0.005 & -0.889 & 0.018 \\
\hline WAST02 & 3021 & 382 & 5 & 500 & 64 & $5.53 \mathrm{E}+05$ & 927.20 & $1.16 \mathrm{E}-(04$ & $1.62 \mathrm{E}+05$ & 881.84 & 0.365 & 0.012 & -0.621 & 0.017 \\
\hline WAST02 & 3021 & 382 & 5 & 500 & 130 & $1.01 \mathrm{E}+06$ & 1312.10 & $1.29 \mathrm{E}-04$ & $3.11 \mathrm{E}+05$ & 1280.80 & 0.589 & 0.005 & -1.173 & 0.013 \\
\hline WAST02 & 3021 & 382 & 5 & 500 & 95 & $7.54 \mathrm{E}+05$ & 1117.68 & $1.26 \mathrm{E}-04$ & $3.12 \mathrm{E}+05$ & 1125.38 & 0.842 & 0.003 & -0.678 & 0.014 \\
\hline WAST02 & 3021 & 382 & 5 & 500 & 82 & $5.00 E+05$ & 887.48 & $1.64 \mathrm{E}-04$ & $2.08 E+05$ & 964.36 & 0.875 & 0.010 & -0.872 & 0.017 \\
\hline WAST02 & 3021 & 382 & 5 & 500 & 127 & $8.44 E+05$ & 1172.00 & $1.51 \mathrm{E}-04$ & $2.70 \mathrm{E}+05$ & 1165.59 & 0.771 & 0.009 & -0.978 & 0.014 \\
\hline
\end{tabular}

Table 2. (cont'd) Morphometric and isotopic data for G. menardii from WAST02 


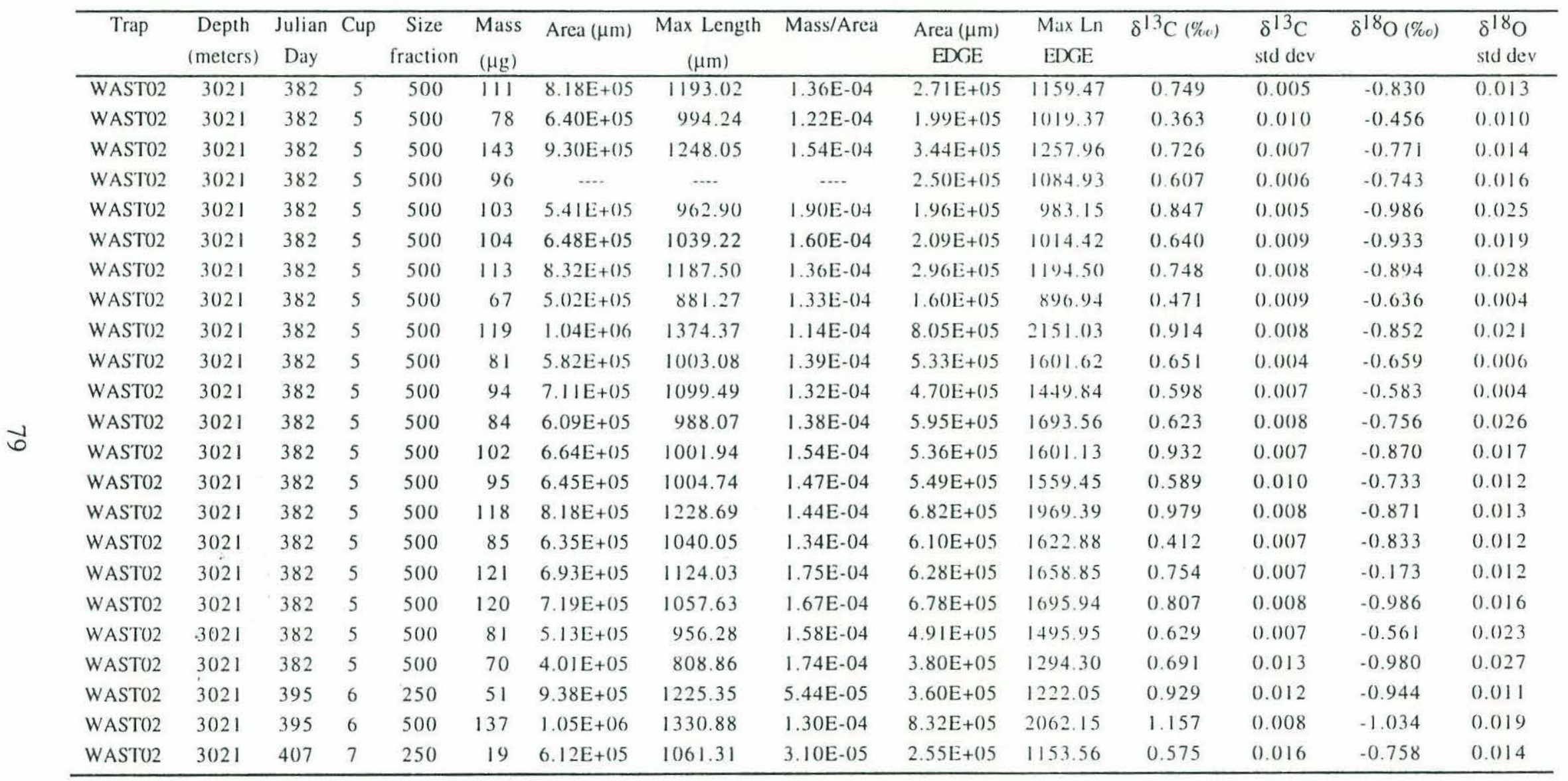

Table 2. (cont'd) Morphometric and isotopic data for $G$. menardii from WAST02 


\begin{tabular}{|c|c|c|c|c|c|c|c|c|c|c|c|c|c|c|}
\hline Trap & $\begin{array}{c}\text { Depth } \\
\text { (meters) }\end{array}$ & $\begin{array}{l}\text { Julian } \\
\text { Day }\end{array}$ & Cup & $\begin{array}{c}\text { Size } \\
\text { fraction }\end{array}$ & $\begin{array}{l}\text { Mass } \\
(\mu g)\end{array}$ & Area $(\mu \mathrm{m})$ & $\begin{array}{c}\text { Max Length } \\
(\mu \mathrm{m})\end{array}$ & Mass/Area & $\begin{array}{c}\text { Area }(\mu \mathrm{m}) \\
\text { EDGE }\end{array}$ & $\begin{array}{l}\text { Max Ln } \\
\text { EDGE }\end{array}$ & $\delta^{13} \mathrm{C}(\%)$ & $\begin{array}{c}\delta^{13} \mathrm{C} \\
\text { std dev }\end{array}$ & $\delta^{18} \mathrm{O}(\%)$ & $\begin{array}{l}\delta^{18} \mathrm{O} \\
\text { sid dev }\end{array}$ \\
\hline WAST03 & 3033 & 516 & 2 & 250 & 89 & $8.47 \mathrm{E}+(05$ & 1272.56 & $1.05 \mathrm{E}-04$ & $3.06 \mathrm{E}+() 5$ & 1185.73 & 0.694 & 0.011 & -1.096 & 0.035 \\
\hline WAST03 & 3033 & 516 & 2 & 250 & 67 & $1.24 \mathrm{E}+06$ & 1393.03 & $5.42 \mathrm{E}-05$ & $3.92 \mathrm{E}+05$ & 1367.71 & 0.602 & 0.014 & -0.923 & 0.015 \\
\hline WAST03 & 3033 & 541 & 4 & 250 & 77 & $1.24 \mathrm{E}+06$ & 1494.42 & $6.22 \mathrm{E}-(05$ & $4.03 E+05$ & 1359.16 & 0.994 & 0.007 & -1.477 & 0.007 \\
\hline WAST03 & 3033 & 541 & 4 & 250 & 63 & $8.61 \mathrm{E}+(05$ & 1178.47 & 7.31E-05 & $3.17 \mathrm{E}+(05$ & 1179.91 & 0.852 & 0.010 & -1.338 & 0.030 \\
\hline WAST03 & 3033 & 541 & 4 & 500 & 150 & $1.03 E+06$ & 1277.34 & $1.46 \mathrm{E}-04$ & $7.18 \mathrm{E}+05$ & 1990.85 & 1.245 & 0.006 & -1.342 & 0.010 \\
\hline WAST03 & 3033 & 541 & 4 & 500 & 135 & $8.81 E+05$ & 1208.24 & $1.53 \mathrm{E}-04$ & $7.46 \mathrm{E}+05$ & 1958.78 & 1.182 & 0.007 & -1.455 & 0.013 \\
\hline WAST03 & 3033 & 541 & 4 & 500 & 100 & $8.47 E+05$ & 1213.20 & $1.18 \mathrm{E}-04$ & $6.65 E+05$ & $19+2.41$ & 0.891 & 0.003 & -1.066 & 0.015 \\
\hline WAST03 & 3033 & 541 & 4 & 500 & 123 & $8.59 \mathrm{E}+05$ & 1220.38 & $1.43 \mathrm{E}-04$ & $7.85 \mathrm{E}+05$ & 1932.29 & 0.923 & 0.005 & -0.907 & 0.015 \\
\hline WAST03 & 3033 & 541 & 4 & 500 & 80 & $6.65 E+(05$ & 1068.01 & $1.20 \mathrm{E}-04$ & $5.95 \mathrm{E}+(05$ & 1682.24 & 0.971 & 0.008 & -0.957 & 0.017 \\
\hline WAST03 & 3033 & 541 & 4 & 500 & 154 & $1.19 \mathrm{E}+06$ & 1413.49 & 1.29E-04 & $8.52 E+(05$ & 2263.69 & 1.045 & 0.014 & -1.229 & 0.018 \\
\hline WAST03 & 3033 & 541 & 4 & 500 & 29 & $6.37 \mathrm{E}+05$ & 984.15 & $4.56 \mathrm{E}-05$ & $5.90 \mathrm{E}+05$ & 1619.87 & 1.633 & 0.016 & -2.083 & 0.037 \\
\hline WAST03 & 3033 & 541 & 4 & 500 & 109 & $8.36 \mathrm{E}+05$ & 1207.58 & $1.30 \mathrm{E}-04$ & $6.46 \mathrm{E}+05$ & 18.37 .97 & 0.851 & 0.005 & -1.060 & 0.017 \\
\hline WAST03 & 3033 & .541 & 4 & 500 & 101 & $7.65 E+05$ & 1157.77 & $1.32 \mathrm{E}-04$ & $7.60 \mathrm{E}+05$ & 1815.45 & 0.949 & 0.012 & -1.129 & 0.005 \\
\hline WAST03 & 3033 & 541 & 4 & 500 & 76 & $5.72 E+05$ & 921.28 & $1.33 \mathrm{E}-04$ & $5.09 E+05$ & 1469.11 & 0.712 & 0.006 & -0.868 & 0.024 \\
\hline WAST03 & 3033 & 541 & 4 & 500 & 107 & $7.40 \mathrm{E}+05$ & 1060.06 & 1.45E-04 & $6.43 \mathrm{E}+05$ & 1679.57 & 1.400 & 0.008 & -1.272 & 0.011 \\
\hline WAST03 & 3033 & 541 & 4 & 500 & 62 & $5.21 E+05$ & 937.73 & $1.19 \mathrm{E}-04$ & $3.70 \mathrm{E}+05$ & 1387.17 & 0.925 & 0.010 & -1.170 & 0.021 \\
\hline WAST03 & 3033 & .541 & 4 & 500 & 145 & $9.68 E+(15)$ & 1314.98 & $1.50 \mathrm{E}-04$ & $9.01 \mathrm{E}+(05$ & 2051.39 & 1.160 & 0.015 & -1.212 & 0.005 \\
\hline WAST03 & 3033 & 541 & 4 & 500 & 163 & $1.12 \mathrm{E}+(06$ & 1389.89 & $1.45 \mathrm{E}-04$ & $8.46 E+(05$ & 2188.69 & 1.017 & 0.009 & -1.053 & 0.012 \\
\hline WASTO3 & 3033 & 554 & 5 & 250 & 52 & -... & -..- & -..- & $3.53 \mathrm{E}+05$ & 1200.13 & 0.927 & 0.009 & -1.260 & 0.005 \\
\hline WAST03 & 3033 & 566 & 6 & 250 & 64 & $4.51 \mathrm{E}+05$ & 901.31 & $1.42 \mathrm{E}-04$ & $3.55 \mathrm{E}+(05$ & 1349.12 & 0.526 & 0.008 & -0.861 & 0.031 \\
\hline WAST03 & 3033 & 566 & 6 & 250 & 64 & --- & $\cdots$ & -.-- & 4.29E+05 & 1425.59 & 0.711 & 0.012 & -0.811 & 0.020 \\
\hline WAST03 & 3033 & 566 & 6 & 250 & 64 & $4.28 E+(05$ & 877.04 & $1.50 \mathrm{E}-04$ & $3.65 E+() 5$ & 1388.64 & 0.745 & 0.013 & -0.956 & 0.017 \\
\hline WAST03 & 3033 & 566 & 6 & 250 & 42 & $5.05 E+05$ & 907.41 & $8.32 \mathrm{E}-05$ & $4.15 E+05$ & 1460.39 & 0.482 & 0.008 & -0.805 & 0.042 \\
\hline WAST03 & 3033 & 566 & 6 & 250 & 55 & $5.13 E+05$ & 978.54 & $1.07 \mathrm{E}-04$ & $5.45 E+05$ & 1554.08 & 0.466 & 0.006 & -0.828 & 0.015 \\
\hline WAST03 & 3033 & 566 & 6 & 250 & 21 & $2.04 E+05$ & 590.44 & $1.03 \mathrm{E}-04$ & $4.16 E+05$ & 1293.24 & 0.566 & 0.029 & -0.411 & 0.063 \\
\hline WAST03 & 3033 & 566 & 6 & 250 & 56 & $4.61 E+05$ & 921.91 & $1.21 \mathrm{E}-04$ & $3.38 \mathrm{E}+05$ & 1340.05 & 0.652 & 0.008 & -1.118 & 0.010 \\
\hline WAST03 & 3033 & 566 & 6 & 250 & 33 & $4.18 \mathrm{E}+05$ & 834.78 & $7.90 \mathrm{E}-05$ & $2.83 E+05$ & 1336.10 & 0.284 & 0.017 & -0.938 & 0.023 \\
\hline
\end{tabular}

Table 2. (cont'd) Morphometric and isotopic data for G. menardii from WAST03 


\begin{tabular}{|c|c|c|c|c|c|c|c|c|c|c|c|c|c|c|}
\hline Trap & $\begin{array}{c}\text { Depth } \\
\text { (meters) }\end{array}$ & $\begin{array}{c}\text { Julian } \\
\text { Day }\end{array}$ & Cup & $\begin{array}{c}\text { Size } \\
\text { fraction }\end{array}$ & $\begin{array}{l}\text { Mass } \\
(\mu g)\end{array}$ & Area $(\mu \mathrm{m})$ & $\begin{array}{c}\text { Max Length } \\
(\mu \mathrm{m})\end{array}$ & Mass/Area & $\begin{array}{c}\text { Area }(\mu \mathrm{m}) \\
\text { EDGE }\end{array}$ & $\begin{array}{l}\text { Max Ln } \\
\text { EDGE }\end{array}$ & $\delta^{13} \mathrm{C}(\%)$ & $\begin{array}{l}\delta^{13} \mathrm{C} \\
\text { std dev }\end{array}$ & $\delta^{18} \mathrm{O}(\%)$ & $\begin{array}{l}\delta^{18} \mathrm{O} \\
\text { sid dev }\end{array}$ \\
\hline WAST03 & 3033 & 566 & 6 & 500 & 78 & $5.32 \mathrm{E}+(05$ & 925.37 & $1.47 \mathrm{E}-04$ & $4.07 E+(15$ & 1429.85 & 0.902 & 0.012 & -1.239 & 0.024 \\
\hline WAST03 & 3() 33 & 566 & 6 & 500 & 75 & $7.19 \mathrm{E}+05$ & 1081.52 & $1.04 \mathrm{E}-(04$ & $4.98 \mathrm{E}+(155$ & 1607.00 & 0.399 & (1).007 & -0.815 & (0.0) 13 \\
\hline WAST03 & 3033 & 566 & 6 & 500 & 91 & $9.13 \mathrm{E}+05$ & 1213.75 & $9.97 \mathrm{E}-05$ & $5.64 \mathrm{E}+(155$ & 1771.77 & 0.740 & 0.008 & -1.001 & 0.014 \\
\hline WAST(0) & 3033 & 566 & 6 & 500 & 61 & $6.44 \mathrm{E}+(05$ & 1047.13 & $9.47 \mathrm{E}-(05$ & $4.44 E+(1) 5$ & 1605.59 & 0.464 & 0.015 & -0.922 & (0).025 \\
\hline WASTO3 & 3033 & 566 & 6 & 500 & 51 & $4.80 \mathrm{E}+05$ & 889.98 & 1.06E-(04 & $3.18 \mathrm{E}+(05$ & 1310.42 & 0.350 & (0). (1) 6 & -0.850 & (0.0.36 \\
\hline WASTO3 & 3033 & 566 & 6 & 500 & 95 & $9.85 E+05$ & 1288.55 & 9.64L-05 & $6.70 \mathrm{E}+05$ & 1987.50 & (0.577 & 0.013 & -0.635 & 0.019 \\
\hline WAST03 & 3033 & 566 & 6 & 500 & 144 & $1.05 E+(06$ & 1335.86 & $1.37 \mathrm{E}-(04$ & $7.95 \mathrm{E}+0.5$ & 2069.19 & 1.061 & 0.003 & -1.105 & 0.014 \\
\hline WAST03 & 3033 & 566 & 6 & 500 & 49 & 4.95E+05 & 921.89 & 9.90Е-(1)5 & $3.49 E+() 5$ & 1327.20 & 0.368 & 0.013 & -0.861 & (0.) (1)25 \\
\hline WAST()3 & 3033 & 566 & 6 & 500 & 86 & $7.57 \mathrm{E}+0.5$ & 1149.72 & $1.14 \mathrm{E}-(04$ & $5.89 \mathrm{E}+05$ & 1738.46 & (). 6661 & 0.007 & -0.938 & 0.020 \\
\hline WAST03 & 3033 & 566 & 6 & 500 & 115 & $8.41 E+05$ & 1207.16 & $1.37 \mathrm{E}-04$ & $6.89 \mathrm{E}+105$ & 1944.59 & 0.937 & 0.003 & -1.260 & 0.008 \\
\hline WAST03 & 3033 & 566 & 6 & 500 & 92 & $8.85 E+(05$ & 1217.73 & 1.04E-(04 & $6.03 E+05$ & 1947.74 & 0.864 & 0.006 & -1.053 & 0.018 \\
\hline WAST03 & 3033 & 566 & 6 & 500 & 84 & $6.28 \mathrm{E}+(05$ & 999.69 & $1.34 \mathrm{E}-(04$ & $4.98 E+05$ & 1591.12 & 0.915 & $0.0(14$ & -1.017 & 0.005 \\
\hline WAST03 & 3033 & 566 & 6 & 500 & 65 & $6.62 \mathrm{E}+(05$ & 1010.37 & $9.83 \mathrm{E}-05$ & $4.38 \mathrm{E}+05$ & 1607.96 & 0.206 & 0.015 & -0.726 & 0.020 \\
\hline WAST03 & 3033 & 579 & 7 & 250 & 48 & $4.67 \mathrm{E}+05$ & 859.82 & $1.03 \mathrm{E}-04$ & $3.82 \mathrm{E}+05$ & 1.377 .76 & 0.807 & 0.021 & -0.883 & 0.043 \\
\hline WAST03 & 3033 & 579 & 7 & 250 & 44 & $2.57 \mathrm{E}+05$ & 684.14 & $1.71 \mathrm{E}-04$ & $2.37 \mathrm{E}+05$ & 1019.41 & 0.617 & 0.017 & -0.904 & 0.004 \\
\hline WAST03 & 3033 & 579 & 7 & 500 & 95 & $6.68 E+05$ & 1062.89 & $1.42 \mathrm{E}-04$ & $5.79 E+05$ & 1651.00 & 1.016 & (0.008 & -1.238 & 0.018 \\
\hline WAST03 & 3033 & 579 & 7 & 500 & 68 & $6.25 E+05$ & 1041.66 & $1.09 \mathrm{E}-04$ & $4.76 E+05$ & 1527.45 & 0.851 & 0.006 & -0.918 & 0.014 \\
\hline WAST03 & 3033 & 591 & 8 & 250 & 18 & $3.70 \mathrm{E}+05$ & 777.38 & $4.87 \mathrm{E}-05$ & $1.74 \mathrm{E}+05$ & 760.18 & 0.502 & 0.019 & -0.367 & 0.054 \\
\hline WAST03 & 3033 & 591 & 8 & 250 & 14 & $5.92 E+(05$ & 996.50 & $2.37 \mathrm{E}-05$ & $2.51 E+05$ & 988.87 & 0.793 & 0.049 & -1.294 & 0.122 \\
\hline WAST03 & 3033 & 604 & 9 & 250 & 51 & $1.20 E+06$ & 1373.13 & $4.25 \mathrm{E}-05$ & $5.21 \mathrm{E}+05$ & 1396.72 & 0.304 & 0.006 & -1.526 & 0.004 \\
\hline WAST03 & 3033 & 604 & 9 & 250 & 33 & $1.08 E+06$ & 1349.28 & $3.06 \mathrm{E}-05$ & $3.24 E+05$ & 1363.70 & 0.108 & 0.005 & -0.132 & 0.053 \\
\hline WAST03 & 3033 & 604 & 9 & 250 & 46 & $1.03 E+06$ & 1363.44 & 4.47E-05 & $3.87 \mathrm{E}+(15$ & 1380.99 & 0.203 & 0.017 & -1.120 & 0.022 \\
\hline WAST03 & 3033 & 604 & 9 & 250 & 39 & $6.06 \mathrm{E}+05$ & 1010.17 & $6.43 \mathrm{E}-05$ & $2.56 \mathrm{E}+05$ & 999.13 & 0.141 & 0.016 & -1.527 & 0.033 \\
\hline WAST03 & 3033 & 604 & 9 & 250 & 41 & $7.06 \mathrm{E}+05$ & 1050.25 & $5.81 \mathrm{E}-05$ & $2.66 \mathrm{E}+05$ & 1037.83 & 0.031 & 0.018 & -1.103 & 0.049 \\
\hline WAST03 & 3033 & 604 & 9 & 250 & 49 & $5.49 E+05$ & 1020.59 & $8.93 \mathrm{E}-05$ & $2.72 E+05$ & 970.63 & 0.222 & 0.015 & -1.260 & 0.013 \\
\hline WAST03 & 3033 & 604 & 9 & 250 & 38 & $4.76 E+05$ & 904.99 & 7.99 E- 05 & $2.30 \mathrm{E}+(15$ & 916.99 & 0.407 & 0.011 & -1.110 & 0.054 \\
\hline WAST03 & 3033 & 604 & 9 & 250 & 42 & $3.96 E+05$ & 778.61 & $1.06 \mathrm{E}-04$ & $2.61 \mathrm{E}+05$ & 840.87 & 0.457 & 0.006 & -0.003 & 0.028 \\
\hline
\end{tabular}

Table 2. (cont'd) Morphometric and isotopic data for $G$. menardii from WAST03 


\begin{tabular}{|c|c|c|c|c|c|c|c|c|c|c|c|c|c|c|}
\hline Trap & $\begin{array}{l}\text { Depth } \\
\text { (meters) }\end{array}$ & $\begin{array}{l}\text { Julian } \\
\text { Day }\end{array}$ & Cup & $\begin{array}{c}\text { Size } \\
\text { fraction }\end{array}$ & $\begin{array}{l}\text { Mass } \\
(\mu g)\end{array}$ & Area $(\mu \mathrm{m})$ & $\begin{array}{l}\text { Max Length } \\
(\mu \mathrm{m})\end{array}$ & Mass/Area & $\begin{array}{l}\text { Area }(\mu \mathrm{m}) \\
\text { EDGE }\end{array}$ & $\begin{array}{l}\text { Max Ln } \\
\text { EDGE }\end{array}$ & $\delta^{13} \mathrm{C}(\% o)$ & $\begin{array}{l}\delta^{13} \mathrm{C} \\
\text { std dev }\end{array}$ & $\delta^{18} \mathrm{O}(\% o)$ & $\begin{array}{l}\delta^{18} \mathrm{O} \\
\text { sid dev }\end{array}$ \\
\hline WAST03 & 3033 & 604 & 9 & 250 & 31 & $4.28 \mathrm{E}+0.5$ & 936.87 & $7.24 \mathrm{E}-05$ & $2.09 E+05$ & 923.91 & 0.514 & 0.015 & -0.500 & 0.033 \\
\hline WAST03 & 3033 & 604 & 9 & 250 & 33 & $4.27 E+05$ & 842.25 & 7.74E-05 & $1.77 \mathrm{E}+05$ & 841.18 & 0.174 & 0.031 & -1.151 & 0.047 \\
\hline WAST03 & 3033 & 604 & 9 & 250 & 36 & $4.69 \mathrm{E}+(05$ & 919.57 & 7.67E-05 & $2.25 E+(05$ & 911.19 & 0.344 & 0.019 & -0.235 & 0.043 \\
\hline WAST(03 & 3033 & 604 & 9 & 250 & 36 & $3.92 \mathrm{E}+05$ & 810.60 & $9.18 \mathrm{E}-(05$ & $1.94 E+(05$ & 851.63 & 0.215 & 0.035 & -1.129 & 0.031 \\
\hline WAST03 & 3033 & 604 & 9 & 250 & $\cdots$ & $\cdots$ & $\cdots$ & $\cdots$ & $1.70 \mathrm{E}+05$ & 746.09 & $\cdots$ & .... & -... & .... \\
\hline WAST03 & 3033 & 616 & 10 & 250 & 49 & $8.44 E+05$ & 1183.40 & $5.81 \mathrm{E}-05$ & $3.00 \mathrm{E}+05$ & 1108.19 & 0.385 & 0.040 & -0.671 & 0.042 \\
\hline WAST03 & 3033 & 616 & 10 & 250 & 64 & $1.31 E+06$ & 1437.48 & $4.89 \mathrm{E}-05$ & $3.89 \mathrm{E}+(05$ & 1361.68 & 0.072 & 0.011 & -1.222 & 0.023 \\
\hline WAST03 & 3033 & 629 & 11 & 250 & 39 & $9.19 \mathrm{E}+05$ & 1228.50 & $4.24 \mathrm{E}-05$ & $2.70 \mathrm{E}+05$ & 1212.04 & 0.366 & 0.008 & -0.342 & 0.014 \\
\hline WAST()3 & 3033 & 629 & 11 & 250 & 36 & $7.23 E+(05$ & 1093.12 & $4.98 E-05$ & $2.84 \mathrm{E}+(15)$ & 1013.72 & 0. .334 & 0.023 & -0.685 & 0.013 \\
\hline WAST03 & 3033 & 629 & 11 & 250 & 33 & $6.85 E+05$ & 1062.16 & $4.82 \mathrm{E}-05$ & $2.82 \mathrm{E}+05$ & 1084.05 & 0.727 & (0.024 & -0.954 & 0.018 \\
\hline WAST03 & 3033 & 629 & 11 & 500 & 86 & $1.76 \mathrm{E}+06$ & 1675.21 & $4.89 \mathrm{E}-05$ & $6.46 \mathrm{E}+05$ & 1668.78 & 0.634 & 0.011 & -0.565 & 0.011 \\
\hline
\end{tabular}

Table 2. (cont'd) Morphometric and isotopic data for $G$. menardii from WAST03 


\begin{tabular}{|c|c|c|c|c|c|c|c|c|c|c|c|}
\hline Trap & Depth (m) & Julian Day & Cup & Mass $(\mu \mathrm{g})$ & Area $(\mu \mathrm{m})$ & Max Length $(\mu \mathrm{m})$ & Mass/Area & $\delta^{13} \mathrm{C}(\%)$ & $\delta^{13} \mathrm{C}$ std dev & $\delta^{18} \mathrm{O}(\%)$ & $\delta^{18} \mathrm{O}$ std dev \\
\hline WAST01 & 3024 & 163 & 3 & 44 & $2.20 \mathrm{E}+05$ & 610.24 & $2.00 \mathrm{E}-04$ & 1.982 & 0.009 & -1.358 & 0.014 \\
\hline WAST01 & 1023 & 189 & 5 & 38 & $1.67 E+05$ & 509.06 & $2.28 \mathrm{E}-() 4$ & $-\cdots$ & -... & --.- & -... \\
\hline WAST0I & 1023 & 189 & 5 & 21 & $1.79 E+(05$ & 551.34 & $1.18 \mathrm{E}-(1) 4$ & $\cdots$ & -..- & --- & $\cdots$ \\
\hline WAST0I & 3024 & 189 & 5 & 66 & $3.18 \mathrm{E}+05$ & 726.05 & 2.07E-()4 & 0.759 & 0.003 & -1.211 & 0.008 \\
\hline WAST01 & 3024 & 189 & 5 & 31 & $1.91 \mathrm{E}+05$ & 550.24 & 1.63E-()4 & 0.439 & 0.010 & -0.984 & 0.032 \\
\hline WAST()I & 3024 & 189 & 5 & 35 & $1.35 \mathrm{E}+(05$ & 462.50 & $2.59 \mathrm{E}-(1) 4$ & 1.141 & ().(1)20 & -1.139 & 0.0 .37 \\
\hline WAST01 & 3024 & 189 & 5 & 53 & $2.91 \mathrm{E}+05$ & 678.76 & $1.82 \mathrm{E}-(04$ & 0.948 & 0.009 & -1.118 & 0.017 \\
\hline WAST01 & 3024 & 189 & 5 & 45 & $2.77 \mathrm{E}+05$ & 669.25 & $1.62 \mathrm{E}-(04$ & 0.784 & 0.004 & -1.185 & 0.019 \\
\hline WASIOI & 3024 & 189 & 5 & 52 & $2.90 \mathrm{E}+05$ & 680.52 & 1.79E:-(04 & (0.730 & 0.010 & -1.389 & 0.008 \\
\hline WAST01 & 3024 & 189 & 5 & 27 & $2.42 \mathrm{E}+(05$ & 641.00 & $1.11 \mathrm{E}-(04$ & 0.275 & (0.0)11 & -1.118 & (0.0)23 \\
\hline WAST()I & 3024 & 189 & 5 & 45 & $2.83 E+() 5$ & $7(05.52$ & $1.59[-(1) 4$ & (). 653 & ().0(1)9 & -1.165 & (0.019 \\
\hline WAST0I & 3024 & 189 & 5 & 35 & $2.83 \mathrm{E}+05$ & 689.73 & 1.24E-()4 & 0.519 & 0.012 & -1.206 & 0.012 \\
\hline WAST0I & 3024 & 189 & 5 & 59 & $3.33 E+05$ & 729.09 & $1.77 \mathrm{E}-(1) 4$ & 1.090 & 0.014 & -1.429 & (0.005 \\
\hline WAST01 & 3024 & 189 & 5 & 43 & $2.82 E+05$ & 664.22 & I.52E-(1)4 & 0.753 & 0.011 & -1.142 & (0.027 \\
\hline WAST01 & 3024 & 189 & 5 & 42 & $2.55 E+05$ & 629.04 & $1.65 E-(14$ & 0.480 & 0.023 & -0.839 & (). ()24 \\
\hline WAST01 & 3024 & 189 & 5 & 44 & $2.38 \mathrm{E}+05$ & 616.90 & $1.85 \mathrm{E}-(04$ & (). 945 & 0.006 & -1.296 & 0.008 \\
\hline WAST0I & 3024 & 189 & 5 & 41 & $2.64 \mathrm{E}+05$ & 652.19 & $1.55 \mathrm{E}-(04$ & 0.672 & 0.008 & -1.253 & 0.026 \\
\hline WAST0I & 3024 & 189 & 5 & 48 & $3.15 E+05$ & 701.16 & $1.52 \mathrm{E}-(\mathrm{)} 4$ & (). 645 & 0.009 & -1.201 & 0.008 \\
\hline WAST01 & 3024 & 189 & 5 & 41 & $2.34 \mathrm{E}+05$ & 603.82 & $1.75 E-(1) 4$ & 0.552 & 0.005 & -1.054 & 0.021 \\
\hline WAST01 & 3024 & 189 & 5 & 26 & $2.36 \mathrm{E}+05$ & 614.74 & 1.10E-(1)4 & 0.390 & 0.030 & -1.021 & 0.009 \\
\hline WASTOI & 3() 24 & 189 & 5 & 23 & $1.68 \mathrm{E}+05$ & 521.98 & $1.37 \mathrm{E}-() 4$ & (0.390 & 0.013 & -1.008 & ().()28 \\
\hline WAST01 & 3024 & 189 & 5 & 43 & $2.73 E+05$ & 660.61 & $1.58 \mathrm{E}-04$ & 0.877 & 0.012 & -1.152 & 0.012 \\
\hline WAST01 & 3024 & 189 & 5 & 38 & $2.42 \mathrm{E}+05$ & 623.91 & $1.57 \mathrm{E}-(04$ & 0.604 & 0.013 & -1.003 & 0.031 \\
\hline WASTOI & 3024 & 189 & 5 & 34 & $2.08 \mathrm{E}+05$ & 574.47 & $1.64 \mathrm{E}-(04$ & 0.866 & 0.009 & -1.225 & 0.031 \\
\hline WAST(01 & 3() 24 & 189 & 5 & 29 & $1.75 E+05$ & 520.11 & $1.66 \mathrm{E}-() 4$ & (0. 454 & 0.020 & -0.631 & 0.015 \\
\hline WAST01 & 3024 & 189 & 5 & 53 & $3.28 \mathrm{E}+05$ & 689.97 & $1.62 \mathrm{E}-() 4$ & 1.334 & 0.009 & -1.396 & 0.014 \\
\hline WAST01 & 3024 & 189 & 5 & 78 & $3.88 \mathrm{E}+05$ & 746.76 & $2.01 \mathrm{E}-(04$ & 0.926 & 0.008 & -1.461 & 0.012 \\
\hline WAST01 & 3024 & 189 & 5 & 60 & $2.92 \mathrm{E}+05$ & 673.42 & $2.06 \mathrm{E}-(1) 4$ & 1.107 & 0.008 & -1.263 & 0.020 \\
\hline WAST01 & 3024 & 189 & 5 & 61 & $3.29 E+05$ & 715.25 & $1.85 \mathrm{E}-(04$ & 0.833 & 0.014 & -1.189 & 0.020 \\
\hline WAST01 & 3024 & 189 & 5 & 66 & $3.46 \mathrm{E}+05$ & 741.84 & $1.91 \mathrm{E}-(04$ & 1.248 & 0.006 & -1.480 & 0.010 \\
\hline WASTOI & 3024 & 189 & 5 & 61 & $3.38 \mathrm{E}+05$ & 715.57 & $1.80 \mathrm{E}-(14$ & 1.036 & 0.008 & -1.488 & 0.022 \\
\hline
\end{tabular}

Table 3. Morphometric and isotopic data for Neogloboquadrina dutertrei from three western Arabian Sea traps (WAST01, 02, 03) 


\begin{tabular}{|c|c|c|c|c|c|c|c|c|c|c|c|}
\hline Trap & Depth (m) & Julian Day & Cup & Mass $(\mu \mathrm{g})$ & Area $(\mu \mathrm{m})$ & Max Length $(\mu \mathrm{m})$ & Mass/Area & $\delta^{13} \mathrm{C}(\%)$ & $\delta^{13} \mathrm{C}$ std dev & $\delta^{18} \mathrm{O}(\% \circ)$ & $\delta^{18} \mathrm{O}$ std dev \\
\hline WAST01 & 3024 & 189 & 5 & 59 & $3.11 \mathrm{E}+05$ & 726.25 & $1.90 \mathrm{E}-04$ & 0.863 & 0.007 & -1.213 & 0.009 \\
\hline WAST01 & 3() 24 & 189 & 5 & 32 & -..- & -..- & -..- & -..- & -... & -..- &.--- \\
\hline WAST0I & 3024 & 202 & 6 & 55 & $2.82 \mathrm{E}+05$ & 645.73 & $1.95 \mathrm{E}-(04$ & 0.956 & 0.014 & -1.063 & (0.)(022 \\
\hline WAST01 & 3024 & 202 & 6 & 43 & $2.59 \mathrm{E}+05$ & 641.35 & $1.66 \mathrm{E}-04$ & 0.257 & 0.007 & -1.001 & 0.013 \\
\hline WAST01 & 3024 & 202 & 6 & 53 & $3.11 \mathrm{E}+(05$ & 677.97 & 1.7()$E-(04$ & 0.687 & 0. 008 & -1.188 & 0.008 \\
\hline WAST(01 & 3024 & 202 & 6 & 44 & $2.80 \mathrm{E}+05$ & 646.02 & $1.57 \mathrm{E}-(04$ & 0.889 & 0.011 & -1.170 & 0.026 \\
\hline WAST01 & 3024 & 202 & 6 & 49 & $2.75 E+05$ & 667.17 & $1.78 \mathrm{E}-04$ & 0.354 & 0.013 & -0.989 & 0.016 \\
\hline WAST0I & 3024 & 202 & 6 & 47 & $2.81 E+05$ & 641.43 & $1.67 \mathrm{E}-(04$ & 0.875 & 0.004 & -1.322 & 0.019 \\
\hline WAST()I & 3024 & 202 & 6 & 50 & $2.99 \mathrm{E}+05$ & 672.73 & $1.67 \mathrm{E}-(04)$ & 0.672 & $0.0(1) 3$ & -1.206 & (0.).026 \\
\hline WAST01 & 3024 & 202 & 6 & 38 & $2.65 \mathrm{E}+05$ & 636.35 & $1.43 \mathrm{E}-(04$ & 0.576 & 0.011 & -1.304 & 0.018 \\
\hline WAST0I & 3() 24 & 202 & 6 & 47 & $2.82 \mathrm{E}+05$ & 657.49 & $1.67 \mathrm{E}-(04$ & 0.843 & 0.009 & -1.120 & 0.012 \\
\hline WAST01 & 3024 & 202 & 6 & 46 & $2.53 \mathrm{E}+05$ & 649.95 & $1.82 \mathrm{E}-(04$ & 0.367 & 0.008 & -0.960 & 0.029 \\
\hline WAST01 & 3024 & 202 & 6 & 55 & $2.77 \mathrm{E}+05$ & 651.23 & $1.99 \mathrm{E}-04$ & 0.577 & 0.014 & -1.222 & 0.012 \\
\hline WAST01 & 3024 & 202 & 6 & 52 & $3.05 E+05$ & 682.43 & $1.71 \mathrm{E}-(04$ & 1.147 & 0.006 & -1.453 & 0.013 \\
\hline WAST01 & 3024 & 202 & 6 & 41 & $2.47 \mathrm{E}+05$ & 620.57 & $1.66 \mathrm{E}-() 4$ & 0.560 & 0.012 & -0.940 & 0.027 \\
\hline WAST01 & 3024 & 202 & 6 & 30 & $2.03 E+05$ & 573.13 & $1.48 \mathrm{E}-04$ & 0.239 & 0.009 & -0.990 & 0.017 \\
\hline WAST01 & 3024 & 202 & 6 & 32 & $1.95 E+05$ & 547.71 & $1.64 \mathrm{E}-04$ & 0.233 & 0.012 & -1.049 & 0.026 \\
\hline WAST01 & 3() 24 & 202 & 6 & 43 & $2.88 \mathrm{E}+(05$ & 667.35 & 1.49E-(04 & 0.411 & 0.012 & -1.098 & 0.026 \\
\hline WAST0I & 3024 & $2(12$ & 6 & 40) & $2.61 \mathrm{E}+05$ & 644.26 & $1.53 \mathrm{E}-() 4$ & 0.202 & 0.004 & -1.300 & (0.015 \\
\hline $\begin{array}{l}\text { WAST01 } \\
\text { WAST01 }\end{array}$ & 3024 & $\begin{array}{l}202 \\
202\end{array}$ & $\begin{array}{l}6 \\
6\end{array}$ & 42 & $2.67 \mathrm{E}+05$ & 656.88 & $1.57 \mathrm{E}-() 4$ & 0.343 & 0.006 & -1.278 & 0.001 \\
\hline $\begin{array}{l}\text { WAST01 } \\
\text { WAST01 }\end{array}$ & $\begin{array}{l}3024 \\
3(024\end{array}$ & $\begin{array}{l}202 \\
202\end{array}$ & $\begin{array}{l}6 \\
6\end{array}$ & 46 & $2.76 \mathrm{E}+(05$ & 649.86 & 1.67E-(04 & 0.367 & 0.002 & -1.257 & 0.008 \\
\hline WASTOI & 3024 & 202 & $\begin{array}{l}6 \\
6\end{array}$ & $\begin{array}{l}49 \\
31\end{array}$ & $2.59 \mathrm{E}+05$ & 656.91 & 1.89E-()4 & (0.671 & $\begin{array}{l}0.010 \\
0010\end{array}$ & $\begin{array}{r}-1.234 \\
-0774\end{array}$ & $\begin{array}{l}0.010 \\
0(027\end{array}$ \\
\hline WAST01 & 3024 & 202 & 6 & $\begin{array}{l}31 \\
38\end{array}$ & $2.58 \mathrm{E}+(05$ & 658.11 & 1.20E-()4 & (0.278 & $\begin{array}{l}0.010 \\
0.009\end{array}$ & $\begin{array}{l}-0.779 \\
-0.772\end{array}$ & $\begin{array}{l}0 .(1) 27 \\
0.020\end{array}$ \\
\hline WAST01 & 3024 & 202 & 6 & $\begin{array}{l}38 \\
39\end{array}$ & $2.28 \mathrm{E}+05$ & 598.46 & 1.67E-04 & 0.373 & $\begin{array}{l}0.009 \\
0.011\end{array}$ & $\begin{array}{l}-0.112 \\
-1.279\end{array}$ & $\begin{array}{l}0.020 \\
0.012\end{array}$ \\
\hline WAST01 & 3024 & 202 & 6 & $\begin{array}{l}39 \\
42\end{array}$ & $2.68 \mathrm{E}+05$ & 663.82 & 1.46E-(04 & $\begin{array}{l}0.871 \\
0.632\end{array}$ & $\begin{array}{l}0.011 \\
0.007\end{array}$ & -1.209 & $\begin{array}{l}0.012 \\
0.008\end{array}$ \\
\hline WAST01 & 3024 & 202 & 6 & $\begin{array}{l}42 \\
32\end{array}$ & $\begin{array}{l}2.59 \mathrm{E}+05 \\
212 \mathrm{~F}+05\end{array}$ & $\begin{array}{l}631.75 \\
599.76\end{array}$ & $\begin{array}{l}1.62 \mathrm{E}-(04 \\
1.51 \mathrm{E}-04\end{array}$ & $\begin{array}{l}0.632 \\
0.158\end{array}$ & 0.005 & -0.980 & $\begin{array}{l}0.008 \\
0.020\end{array}$ \\
\hline WAST01 & 3024 & 202 & 6 & $\begin{array}{l}32 \\
35\end{array}$ & $\begin{array}{l}2.12 \mathrm{E}+05 \\
1.96 \mathrm{E}+05\end{array}$ & 544.56 & $1.78 \mathrm{E}-(04$ & 0.599 & 0.012 & -0.655 & 0.029 \\
\hline WAST0I & 3024 & 202 & 6 & 32 & $1.99 E+05$ & 556.21 & $1.61 \mathrm{E}-(04$ & 0.650 & 0.008 & -0.952 & 0.031 \\
\hline WAST01 & 3024 & 202 & 6 & 45 & $2.84 \mathrm{E}+05$ & 658.38 & $1.58 \mathrm{E}-04$ & 0.200 & 0.008 & -1.041 & 0.026 \\
\hline WAST0I & 3024 & 202 & 6 & 43 & $2.48 \mathrm{E}+05$ & 605.04 & $1.74 \mathrm{E}-04$ & 0.226 & 0.003 & -1.021 & 0.014 \\
\hline
\end{tabular}

Table 3. (cont'd) Morphometric and isotopic data for $N$. dutertrei from WAST01 


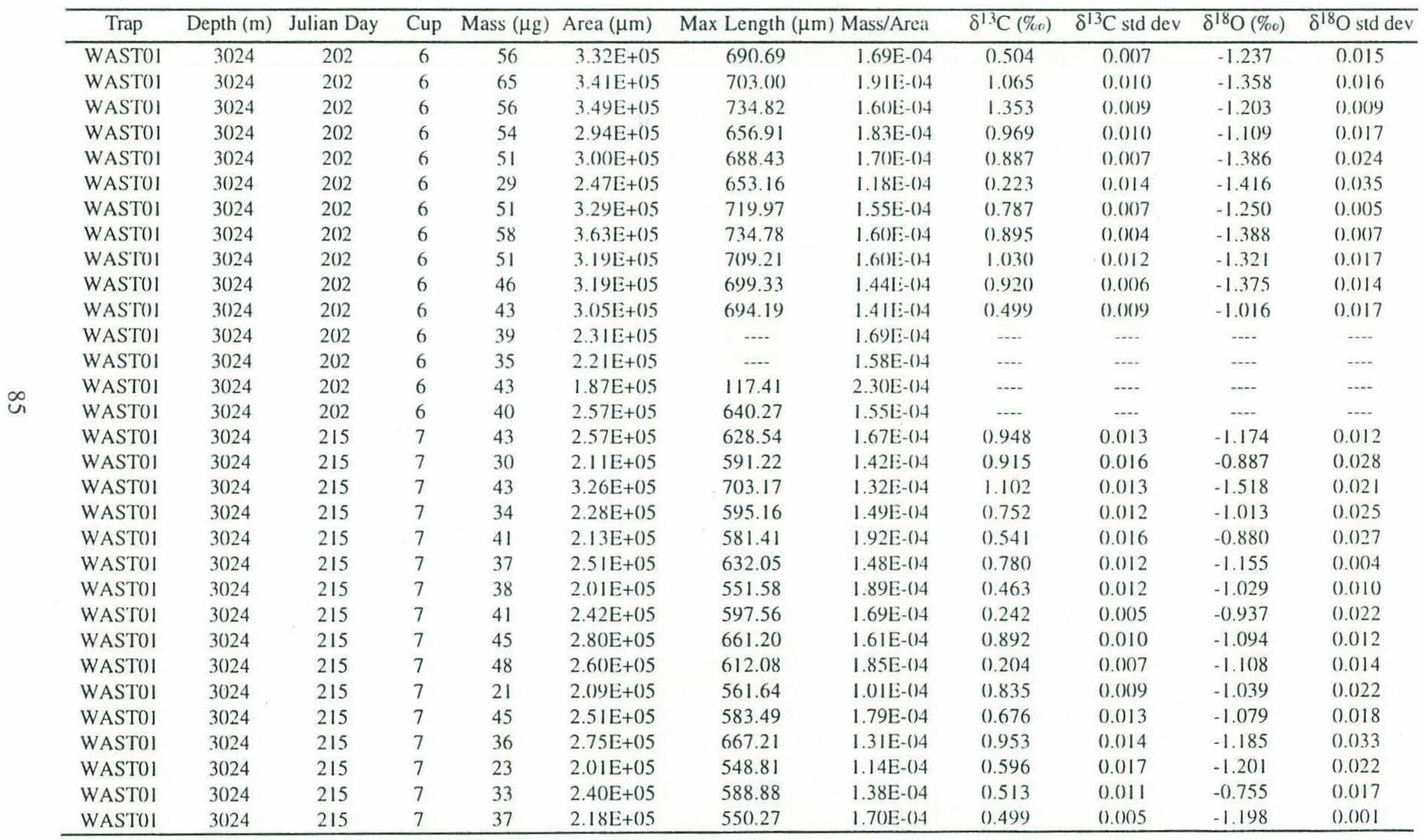

Table 3. (cont'd) Morphometric and isotopic data for $N$. dutertrei from WAST01 


\begin{tabular}{|c|c|c|c|c|c|c|c|c|c|c|c|}
\hline Trap & Depth (m) & Julian Day & Cup & Mass $(\mu \mathrm{g})$ & Area $(\mu \mathrm{m})$ & Max Length $(\mu \mathrm{m})$ & Mass/Area & $\delta^{1,3} \mathrm{C}(\% \circ)$ & $\delta^{13} \mathrm{C}$ std dev & $\delta^{18} \mathrm{O}(\%(1)$ & $\delta^{18} \mathrm{O}$ std dev \\
\hline WAST01 & 3024 & 215 & 7 & 43 & $2.71 E+05$ & 659.30 & $1.59 \mathrm{E}-04$ & 0.889 & 0.015 & -0.803 & 0.025 \\
\hline WAST01 & 3024 & 215 & 7 & 24 & $1.80 E+05$ & 514.00 & $1.34 \mathrm{E}-() 4$ & 0.456 & 0.010 & -0.788 & 0.026 \\
\hline WAST01 & 3024 & 215 & 7 & 49 & $2.73 E+(05$ & 649.27 & 1.8()$E-() 4$ & 0.901 & 0.010 & $-(0.982$ & (0.018 \\
\hline WAST01 & 3() 24 & 215 & 7 & 28 & $1.85 E+05$ & 510.73 & $1.51 \mathrm{E}-() 4$ & (0.313 & (0.010 & -1.040 & 0.006 \\
\hline WASTOI & 3024 & 215 & 7 & 34 & $1.81 \mathrm{E}+(05$ & 513.85 & $1.88 \mathrm{E}-(1) 4$ & (0.586 & 0.011 & -1.096 & 0.012 \\
\hline WASTO1 & 3024 & 215 & 7 & 36 & $2.47 \mathrm{E}+(05$ & 609.90 & $1.46 \mathrm{E}-() 4$ & (0.687 & 0.006 & -0.991 & (). () 23 \\
\hline WASTOI & 3024 & 215 & 7 & 37 & $2.13 E+05$ & 559.43 & $1.74 \mathrm{E}-() 4$ & 0.624 & 0.022 & -0.922 & (0.014 \\
\hline WAST01 & 3024 & 215 & 7 & 31 & $1.95 E+05$ & 541.94 & $1.59 \mathrm{E}-(1) 4$ & (0.242 & 0.018 & -0.825 & 0.010 \\
\hline WAST0I & 3024 & 215 & 7 & 26 & $1.89 E+05$ & 519.15 & $1.38 \mathrm{E}-() 4$ & (0.665 & 0.004 & -0.776 & 0.031 \\
\hline WASTOI & 3() 24 & 215 & 7 & 22 & $1.64 \mathrm{E}+05$ & 498.70 & 1.35E-(14 & (0.551 & (). () 24 & -0.883 & (0.0.36 \\
\hline WASTOI & 3024 & 215 & 7 & 39 & $2.41 \mathrm{E}+() 5$ & 608.96 & 1.62E-(1)4 & (0. 408 & 0.009 & -0.910 & (0.0)18 \\
\hline WAST0I & 3024 & 215 & 7 & 21 & $1.35 E+05$ & 460.09 & $1.56 \mathrm{E}-(04$ & (). 493 & 0.011 & -0.605 & 0.014 \\
\hline WAST0I & 3024 & 215 & 7 & 27 & $1.76 E+05$ & 533.93 & $1.53 \mathrm{E}-(04$ & (0.673 & 0.009 & -1.121 & $0 .(040$ \\
\hline WASTOI & 3() 24 & 215 & 7 & 40 & $2.52 E+05$ & 605.26 & 1.59E-(04 & (0.549 & 0.016 & -1.238 & 0.015 \\
\hline WAST0I & 3024 & 215 & 7 & 27 & $1.70 \mathrm{E}+05$ & 515.26 & $1.58 \mathrm{E}-(04$ & 0.635 & 0.009 & -0.334 & 0.039 \\
\hline WAST0I & 3024 & 215 & 7 & 25 & $1.70 \mathrm{E}+05$ & 498.91 & $1.47 \mathrm{E}-(1) 4$ & 0.469 & 0.020 & -0.859 & 0.031 \\
\hline WAST0I & 3024 & 215 & 7 & 41 & $2.03 E+05$ & 538.75 & $2.02 \mathrm{E}-(14$ & 0.669 & 0.008 & -0.965 & 0.032 \\
\hline WAST01 & 3024 & 215 & 7 & 22 & $1.44 E+05$ & 462.52 & $1.53 \mathrm{E}-() 4$ & -..- & --.- & --- & -... \\
\hline WASTOI & 3024 & 215 & 7 & 26 & $2.03 \mathrm{E}+05$ & 553.85 & $1.28 \mathrm{E}-(04$ & $\cdots$ & $\cdots$ & $\cdots$ & --.- \\
\hline WAST01 & 3024 & 215 & 7 & 13 & $1.65 E+05$ & 489.70 & $7.89 \mathrm{E}-(05$ & --.- & -.. & -..- & --.. \\
\hline WAST01 & 3024 & 228 & 8 & 36 & $2.06 E+05$ & 548.53 & $1.75 E-(04$ & 0.064 & 0.008 & -0.972 & 0.020 \\
\hline WASTOI & 3024 & 228 & 8 & 14 & $1.58 \mathrm{E}+05$ & 486.64 & $8.85 E-(05$ & 0.213 & 0.023 & -0.595 & 0.017 \\
\hline WAST0I & 3024 & 228 & 8 & 35 & $2.09 E+05$ & 582.37 & $1.68 \mathrm{E}-(04$ & 0.155 & 0.010 & -0.720 & 0.025 \\
\hline WASTOI & 3024 & 228 & 8 & 50 & $2.42 \mathrm{E}+05$ & 632.84 & $2.06 \mathrm{E}-(1) 4$ & 0.337 & 0.007 & -1.227 & 0.013 \\
\hline WAST01 & 3024 & 228 & 8 & 34 & 2.(04E+(05 & 553.01 & $1.67 \mathrm{E}-(1) 4$ & 0.888 & 0.018 & -0.465 & 0.031 \\
\hline WAST0I & 3024 & 228 & 8 & 38 & $1.92 \mathrm{E}+05$ & 541.58 & $1.98 \mathrm{E}-(04$ & 0.072 & 0.004 & -1.023 & 0.014 \\
\hline WAST01 & 3024 & 228 & 8 & 42 & $2.13 \mathrm{E}+05$ & 600.40 & $1.97 \mathrm{E}-() 4$ & 0.309 & 0.016 & -0.851 & 0.024 \\
\hline WAST01 & 3() 24 & 228 & 8 & 38 & $1.97 \mathrm{E}+05$ & 542.78 & $1.93 \mathrm{E}-() 4$ & 0.463 & 0.021 & -0.635 & 0.031 \\
\hline WAST01 & 3024 & 228 & 8 & 45 & $2.57 \mathrm{E}+05$ & 639.92 & $1.75 E-(14$ & 0.434 & 0.011 & -1.160 & 0.017 \\
\hline WAST0I & 3024 & 228 & 8 & 34 & $1.92 \mathrm{E}+05$ & 554.56 & $1.77 \mathrm{E}-(04$ & 0.481 & 0.026 & -0.671 & 0.017 \\
\hline WAST01 & 3024 & 228 & 8 & 43 & $2.09 \mathrm{E}+05$ & 551.36 & $2.06 \mathrm{E}-(14$ & 0.336 & 0.017 & -1.149 & 0.016 \\
\hline
\end{tabular}

Table 3. (cont'd) Morphometric and isotopic data for $N$. dutertrei from WAST01 


\begin{tabular}{|c|c|c|c|c|c|c|c|c|c|c|c|}
\hline Trap & Depth (m) & Julian Day & Cup & Mass $(\mu \mathrm{g})$ & Area $(\mu \mathrm{m})$ & Max Length $(\mu \mathrm{m})$ & Mass/Area & $\delta^{1.3} \mathrm{C}(\%)$ & $\delta^{13} \mathrm{C}$ std dev & $\delta^{18} \mathrm{O}(\%)$ & $\delta^{18} \mathrm{O}$ sid dev \\
\hline WAST01 & 3024 & 228 & 8 & 37 & $2.02 \mathrm{E}+05$ & 544.18 & $1.83 \mathrm{E}-(04$ & 0.192 & 0.007 & -0.752 & 0.053 \\
\hline WAST01 & 3024 & 228 & 8 & 44 & $2.39 E+(05$ & 615.01 & $1.84 \mathrm{E}-(04$ & 0.413 & 0.018 & $-(0.749$ & 0.024 \\
\hline WAST0I & 3024 & 228 & 8 & 41 & $1.97 \mathrm{E}+(05$ & 555.64 & $2.08 \mathrm{E}-(0) 4$ & 0.570 & 0.012 & $-(0.807$ & 0.(1)24 \\
\hline WAST01 & 3024 & 228 & 8 & 37 & $1.87 \mathrm{E}+(05$ & 523.24 & $1.98 \mathrm{E}-(04$ & 0.296 & 0.013 & -0.963 & 0.015 \\
\hline WAST0I & 3024 & 228 & 8 & 23 & $1.42 \mathrm{E}+05$ & 470.22 & $1.62 \mathrm{E}-04$ & 0.241 & 0.016 & -0.414 & 0.031 \\
\hline WAST0I & 3024 & 228 & 8 & 41 & $2.12 \mathrm{E}+05$ & 565.02 & $1.93 \mathrm{E}-(04$ & (0.254 & 0.009 & -0.989 & 0.020 \\
\hline WAST01 & 3024 & 228 & 8 & 33 & $2.02 \mathrm{E}+05$ & 553.50 & $1.64 \mathrm{E}-04$ & 0.362 & 0.013 & -0.837 & 0.009 \\
\hline WAST01 & 3024 & 228 & 8 & 29 & $1.68 \mathrm{E}+(05$ & 515.11 & $1.73 E-() 4$ & 0.292 & 0.016 & -0.708 & 0.009 \\
\hline WAST01 & 3024 & 228 & 8 & 36 & $2.03 \mathrm{E}+(05$ & 537.16 & 1.77E-(04 & (0.190 & 0.008 & -1.022 & 0.028 \\
\hline WAST0I & 3024 & 228 & 8 & 41 & $2.13 \mathrm{E}+05$ & 579.54 & 1.92E-(04 & (). 079 & (0.012 & -1.103 & 0.(1)24 \\
\hline WAST01 & 3024 & 228 & 8 & 27 & $1.81 \mathrm{E}+(05$ & 521.62 & 1.49E-()4 & (0.243 & 0.008 & -0.430 & 0.042 \\
\hline WAST01 & 3024 & 228 & 8 & 35 & $1.89 \mathrm{E}+05$ & 538.86 & $1.85 \mathrm{E}-(04$ & 0.755 & 0.007 & -1.152 & 0.009 \\
\hline WAST0I & 3024 & 228 & 8 & 31 & $2.06 \mathrm{E}+05$ & 551.63 & $1.51 \mathrm{E}-(04$ & 0.479 & 0.013 & -0.661 & 0.009 \\
\hline WAST01 & 3024 & 228 & 8 & 20 & $1.50 \mathrm{E}+05$ & 479.93 & $1.34 \mathrm{E}-(04$ & (). 224 & 0.016 & -0.853 & 0.026 \\
\hline WAST01 & 3024 & 228 & 8 & 37 & $1.89 \mathrm{E}+05$ & 540.44 & $1.96 \mathrm{E}-04$ & 0.087 & 0.013 & -0.695 & 0.032 \\
\hline WAST01 & 3024 & 228 & 8 & 40 & $1.93 E+05$ & 559.00 & $2.08 \mathrm{E}-(04$ & 0.530 & 0.003 & -0.889 & 0.020 \\
\hline WAST(01 & 3024 & 228 & 8 & 21 & $1.30 \mathrm{E}+05$ & 446.05 & 1.62E-(04 & 0.317 & 0.029 & -0.326 & 0.046 \\
\hline WAST01 & 3024 & 228 & 8 & 35 & $1.79 E+05$ & 531.49 & $1.96 \mathrm{E}-() 4$ & 0.316 & 0.012 & -1.001 & 0.023 \\
\hline WAST01 & 3024 & 228 & 8 & 39 & $1.88 \mathrm{E}+05$ & 522.09 & 2.08E-(04 & (0.662 & 0.016 & -1.120 & 0.018 \\
\hline WAST01 & 3024 & 228 & 8 & 38 & $2.06 E+05$ & 566.42 & $1.85 \mathrm{E}-04$ & $-\cdots$ & $-\cdots$ & $-\cdot-\cdot$ & $-\cdots$ \\
\hline WAST()I & $3(1) 24$ & 228 & 8 & 43 & -..- & -..- & $\cdots$ & -..- & --.- & $\cdots$ & $\cdots$ \\
\hline WAST()I & 3024 & 241 & 9 & 51 & $2.47 \mathrm{E}+05$ & 638.67 & 2.07E-(04 & 0.543 & 0.012 & -1.127 & 0.043 \\
\hline WAST0I & 3024 & 241 & 9 & 39 & $2.14 \mathrm{E}+05$ & 553.53 & $1.82 \mathrm{E}-04$ & 0.367 & 0.011 & -0.757 & 0.017 \\
\hline WASTOI & 3024 & 241 & 9 & 39 & $1.74 \mathrm{E}+05$ & 495.80 & $2.25 \mathrm{E}-(04$ & 0.579 & 0.008 & -1.090 & 0.028 \\
\hline WAST01 & 3024 & 241 & 9 & 40 & $2.30 \mathrm{E}+05$ & 587.86 & $1.74 \mathrm{E}-(04$ & 0.583 & 0.019 & -0.959 & 0.030 \\
\hline WAST01 & 1023 & 273 & 11 & 47 & $2.42 \mathrm{E}+05$ & 605.31 & $1.94 \mathrm{E}-04$ & $\cdots$ & --- & $---\cdot$ & $-\cdots$ \\
\hline WAST01 & 1023 & 311 & 13 & 53 & -..- & --- & --- & --.- & --- & -..- & --.- \\
\hline WAST0I & 3024 & 311 & 13 & 39 & $2.34 E+05$ & 603.25 & $1.66 \mathrm{E}-(04$ & 0.816 & 0.016 & -0.986 & 0.041 \\
\hline WAST01 & 3024 & 311 & 13 & 27 & $1.33 E+05$ & 462.31 & $2.03 E-04$ & 0.580 & 0.016 & -0.970 & 0.030 \\
\hline WAST()! & 3024 & 311 & 13 & 27 & $1.35 \mathrm{E}+05$ & 449.04 & 2.00E-04 & 0.607 & 0.007 & -0.752 & 0.023 \\
\hline WAST01 & 3024 & 311 & 13 & 32 & $1.58 \mathrm{E}+05$ & 513.33 & 2.03E-(04 & 1.110 & 0.010 & -1.130 & 0.021 \\
\hline
\end{tabular}

Table 3. (cont'd) Morphometric and isotopic data for $N$. dutertrei from WAST01 


\begin{tabular}{|c|c|c|c|c|c|c|c|c|c|c|c|}
\hline Trap & Depth (m) & Julian Day & Cup & Mass $(\mu \mathrm{g})$ & Area $(\mu \mathrm{m})$ & Max Length $(\mu \mathrm{m})$ & Mass/Area & $\delta^{13} \mathrm{C}(\%)$ & $\delta^{13} \mathrm{C}$ std dev & $\delta^{18} \mathrm{O}(\% 0)$ & $\overline{\delta^{18} \mathrm{O} \text { std dev }}$ \\
\hline WAST02 & 3021 & 343 & 2 & 46 & $2.59 \mathrm{E}+05$ & 637.61 & $1.78 \mathrm{E}-04$ & 1.265 & 0.011 & -1.358 & 0.011 \\
\hline WAST02 & 3021 & 343 & 2 & 37 & $2.22 \mathrm{E}+05$ & 618.53 & 1.67E-()4 & 1.354 & 0.023 & -1.465 & 0.046 \\
\hline WAST02 & 3021 & 343 & 2 & 41 & $2.49 \mathrm{E}+05$ & 610.51 & 1.65E-()4 & 1.477 & 0.008 & -1.558 & ().()17 \\
\hline WAST02 & 3021 & 343 & 2 & 42 & $2.22 \mathrm{E}+05$ & 574.50 & $1.90 \mathrm{E}-() 4$ & 1.635 & 0.008 & -1.595 & 0.010 \\
\hline WAST02 & 3021 & 343 & 2 & 35 & 2.02E+05 & 553.97 & $1.73 \mathrm{E}-(04$ & 0.532 & 0.012 & -1.438 & 0.009 \\
\hline WAST02 & 3021 & 343 & 2 & 47 & $2.53 E+05$ & 592.35 & $1.86 \mathrm{E}-() 4$ & 1.820 & 0.012 & -1.635 & 0.014 \\
\hline WAST02 & 3021 & 343 & 2 & 36 & $2.10 E+05$ & 568.16 & $1.72 \mathrm{E}-(04$ & 1.512 & 0.014 & -1.589 & 0.010 \\
\hline WAST03 & 1085 & 541 & 4 & 53 & $2.68 E+(05$ & 670.60 & $1.98 \mathrm{E}-(04$ & 1.568 & 0.012 & -1.493 & (0.024 \\
\hline WAST03 & 1085 & 541 & 4 & 46 & $2.25 E+05$ & 600.77 & $2.04 \mathrm{E}-04$ & 1.839 & 0.007 & -1.452 & 0.012 \\
\hline WAST03 & 1085 & 541 & 4 & 45 & $2.36 \mathrm{E}+05$ & 609.99 & $1.91 \mathrm{E}-() 4$ & 1.563 & 0.005 & -1.289 & 0.020 \\
\hline WAST03 & 1085 & 541 & 4 & 30 & $2.05 E+05$ & 546.97 & $1.47 \mathrm{E}-(04$ & 1.479 & 0.005 & -1.296 & 0.024 \\
\hline WAST03 & 1085 & 541 & 4 & 47 & $2.19 E+05$ & 566.92 & 2. $14 \mathrm{E}-(04$ & 1.356 & 0.011 & -1.375 & 0.014 \\
\hline WAST03 & 1085 & 541 & 4 & 60 & $2.84 \mathrm{E}+05$ & 685.75 & $2.11 \mathrm{E}-(04$ & 1.518 & 0.009 & -1.412 & 0.016 \\
\hline WAST03 & 1085 & 541 & 4 & 42 & $2.28 \mathrm{E}+05$ & 568.39 & $1.85 \mathrm{E}-(04$ & 1.578 & 0.008 & -1.361 & 0.022 \\
\hline WAST03 & 1085 & 541 & 4 & 48 & $2.58 \mathrm{E}+05$ & 634.87 & $1.86 E-() 4$ & 1.591 & 0.011 & -1.331 & $0 .(022$ \\
\hline WAST03 & 1085 & 541 & 4 & 34 & $1.81 \mathrm{E}+05$ & 527.28 & $1.88 \mathrm{E}-() 4$ & 1.193 & 0.011 & -1.153 & 0.010 \\
\hline WAST03 & 1085 & 541 & 4 & 51 & $2.59 E+05$ & 640.91 & $1.97 \mathrm{E}-(04$ & 1.128 & 0.004 & -1.262 & 0.004 \\
\hline WAST03 & 1085 & 541 & 4 & 45 & $2.50 E+05$ & 627.24 & $1.80 \mathrm{E}-() 4$ & 1.344 & 0.007 & -1.352 & 0.013 \\
\hline WAST03 & 1085 & 541 & 4 & 47 & $2.75 E+(05$ & 661.43 & $1.71 \mathrm{E}-(04$ & 1.411 & (0.012 & -1.167 & 0.011 \\
\hline WAST03 & 1085 & 541 & 4 & 48 & $2.50 E+05$ & 657.09 & $1.92 \mathrm{E}-(04$ & 1.252 & 0.002 & -1.520 & 0.019 \\
\hline WAST03 & 1085 & 541 & 4 & 60 & $3.29 E+05$ & 719.59 & $1.82 \mathrm{E}-(04$ & 2.075 & (0.014 & -1.579 & (0.015 \\
\hline WAST03 & 1085 & 541 & 4 & 62 & $3.22 \mathrm{E}+05$ & 700.09 & $1.93 \mathrm{E}-(04$ & 1.626 & ().006 & -1.409 & 0.020 \\
\hline WAST03 & 1085 & 541 & 4 & 57 & $2.88 E+05$ & 659.82 & $1.98 \mathrm{E}-(04$ & 1.819 & 0.008 & -1.395 & 0.010 \\
\hline WAST03 & I085 & 541 & 4 & 66 & $3.51 E+(0.5$ & 747.23 & $1.88 \mathrm{E}-(04$ & 1.894 & (0.009 & -1.807 & ().007 \\
\hline WAST03 & 1085 & 541 & 4 & 32 & $1.67 \mathrm{E}+05$ & 501.30 & $1.92 \mathrm{E}-(1) 4$ & 1.133 & 0.017 & -0.886 & (0.045 \\
\hline WAST03 & 1085 & 541 & 4 & 56 & $2.84 \mathrm{E}+(05$ & 683.89 & $1.97 \mathrm{E}-() 4$ & 1.672 & 0.017 & -1.650 & 0.022 \\
\hline WAST03 & 1085 & 541 & 4 & 62 & $3.14 E+(05$ & 675.10 & $1.97 \mathrm{E}-(1) 4$ & 1.715 & 0.007 & -1.563 & 0.008 \\
\hline WAST03 & 1085 & 541 & 4 & 57 & $2.78 E+05$ & 646.66 & $2.05 \mathrm{E}-() 4$ & 1.954 & 0.009 & -1.580 & 0.025 \\
\hline WAST03 & 1085 & 541 & 4 & 37 & $1.93 E+05$ & 529.41 & $1.92 \mathrm{E}-(04$ & -... & --.- & $-\cdots$ & --.- \\
\hline WAST03 & 3033 & 541 & 4 & 55 & $2.74 E+05$ & 663.59 & 2.(01E-(1)4 & 1.555 & 0.008 & -1.490 & $0.0)(19$ \\
\hline
\end{tabular}

Table 3. (cont'd) Morphometric and isotopic data for $N$. dutertrei from WAST02 and WAST03 


\begin{tabular}{|c|c|c|c|c|c|c|c|c|c|c|c|}
\hline Trap & Depth (m) & Julian Day & Cup & Mass $(\mu g)$ & Area $(\mu \mathrm{m})$ & Max Length $(\mu \mathrm{m})$ & Mass/Area & $\delta^{1.3} \mathrm{C}(\%(\%)$ & $\delta^{1.3} \mathrm{C}$ std dev & $\delta^{18} \mathrm{O}(\% a)$ & $\delta^{18} \mathrm{O}$ std dev \\
\hline WAST03 & 3033 & 541 & 4 & 54 & $2.72 E+05$ & 643.43 & $1.98 \mathrm{E}-(04$ & 1.632 & 0.007 & -1.530 & 0.019 \\
\hline WAST03 & 3033 & 541 & 4 & 35 & $2.00 \mathrm{E}+(05$ & 573.34 & 1.75E-(1)4 & 1.845 & ().0)( $) 7$ & -1.544 & (0).035 \\
\hline WAST03 & 3033 & 541 & 4 & 43 & $2.17 \mathrm{E}+(05$ & 586.52 & 1.99E-(04 & 1.141 & ().(1)13 & -1.176 & (0.0)18 \\
\hline WAST03 & 3() 33 & 541 & 4 & 39 & $2.12 \mathrm{E}+05$ & 576.54 & $1.84 \mathrm{E}-() 4$ & 1.604 & 0.011 & -1.269 & 0.009 \\
\hline WAST03 & 3() 33 & 541 & 4 & 35 & $2.17 \mathrm{E}+(05$ & 579.85 & $1.61 \mathrm{E}-(04$ & 0.990 & 0.013 & -1.054 & 0.013 \\
\hline WASIO3 & 3033 & 541 & 4 & 35 & $1.73 \mathrm{E}+(1) 5$ & 527.56 & 2.(1)31:-(1)4 & 1.125 & ().(0)14 & -1.217 & (). 0.32 \\
\hline WASTO3 & 3033 & 541 & 4 & 41 & $2.15 \mathrm{E}+05$ & 556.59 & 1.91E-(1)4 & 1.373 & $0.0(1) 9$ & -1.198 & (). (1)24 \\
\hline WAST03 & 3() 33 & 541 & 4 & 30 & $1.59 \mathrm{E}+05$ & 484.15 & 1.89E-(1)4 & 0.873 & ().(1)11 & -1.019 & (). (1)21 \\
\hline WASTO3 & 3033 & 541 & 4 & 37 & $1.33 \mathrm{E}+05$ & 450.46 & $2.781 \mathrm{E}-104$ & 0.956 & 0.006 & -1.179 & ().(1)11 \\
\hline WAST03 & 3() 33 & 541 & 4 & 48 & $2.84 \mathrm{E}+05$ & 672.28 & 1.69E:-(1)4 & 1.861 & 0.011 & -1.644 & (). (1)22 \\
\hline WASTO3 & 3() .3 .3 & 541 & 4 & 59 & $3.11 \mathrm{~F}+(1) 5$ & 694.55 & 1.9()E:-(1)4 & 1.470 & ().(1) 13 & -1.468 & (0.0)13 \\
\hline WAST03 & 3033 & 541 & 4 & 32 & $1.96 \mathrm{E}+05$ & 561.34 & 1.63E-(1)4 & $\ldots$ & -... & -..- & .... \\
\hline WAST03 & 3033 & 541 & 4 & 48 & $-\cdots$ & -..- & .... & .... & .... & --.- & -..- \\
\hline WAST03 & 1085 & 554 & 5 & 27 & $1.52 \mathrm{E}+05$ & 468.92 & 1.77E-(04 & 1.414 & 0.017 & -1.447 & $0 .(127$ \\
\hline WAST03 & 1085 & 554 & 5 & 13 & $1.03 E+05$ & 399.67 & 1.26E-()4 & ...- & --.- & -.-- & -... \\
\hline WAST03 & 3033 & 554 & 5 & 28 & $1.61 \mathrm{E}+05$ & 477.08 & $1.74 \mathrm{E}-() 4$ & 1.052 & 0.028 & -1.035 & (0.0)14 \\
\hline WAST03 & 3033 & 554 & 5 & 23 & $1.25 \mathrm{E}+05$ & 423.06 & $1.84 \mathrm{E}-(1) 4$ & 1.061 & 0.013 & -0.722 & 0.040 \\
\hline WAST03 & 3033 & 554 & 5 & 50 & $2.12 \mathrm{E}+05$ & 595.98 & $2.36 \mathrm{E}-() 4$ & 1.039 & 0.017 & -1.043 & 0.027 \\
\hline WAST03 & 3033 & 554 & 5 & 14 & $1.36 \mathrm{E}+05$ & 479.95 & $1.03 \mathrm{E}-(04$ & -..- & -.-- & -.-- & -... \\
\hline WAST03 & 1085 & 566 & 6 & 54 & $2.58 \mathrm{E}+05$ & 625.24 & $2.09 \mathrm{E}-04$ & 1.540 & 0.013 & -1.514 & 0.005 \\
\hline WASTO3 & 1085 & 566 & 6 & 37 & $2.52 \mathrm{E}+05$ & 629.01 & $1.47 \mathrm{E}-(04$ & 1.157 & 0.014 & -1.426 & 0.035 \\
\hline WAST03 & 1085 & 566 & 6 & 33 & $1.82 \mathrm{E}+05$ & 529.92 & $1.81 \mathrm{E}-(14$ & 0.869 & 0.014 & -0.876 & 0.009 \\
\hline WAST03 & 1085 & 566 & 6 & 30 & $1.88 \mathrm{E}+05$ & 550.61 & 1.60E-(1)4 & 1.103 & 0.015 & -1.039 & 0.022 \\
\hline WAST03 & 1085 & 566 & 6 & 36 & $1.87 \mathrm{E}+05$ & 538.06 & $1.92 \mathrm{E}-(04$ & 1.238 & 0.015 & -1.275 & 0.013 \\
\hline WAST03 & 1085 & 566 & 6 & 39 & $2.59 \mathrm{E}+05$ & 637.44 & $1.51 \mathrm{E}-(1) 4$ & 1.115 & 0.014 & -1.133 & ().(1)25 \\
\hline WASTO3 & 1085 & 566 & 6 & 20 & $1.39 \mathrm{E}+05$ & 464.07 & $1.44 \mathrm{E}-(1) 4$ & 0.794 & 0.028 & -1.025 & 0.036 \\
\hline WAST03 & 1085 & 566 & 6 & 29 & $1.65 E+05$ & 502.89 & $1.76 \mathrm{E}-(04$ & 0.805 & 0.013 & -0.948 & 0.025 \\
\hline WAST03 & 1085 & 566 & 6 & 48 & $2.33 \mathrm{E}+(05$ & 586.72 & $2.06 \mathrm{E}-() 4$ & $\cdots$ & -... & -.-. & --.. \\
\hline WAST03 & 1085 & 566 & 6 & 30 & $1.59 \mathrm{E}+05$ & 496.58 & $1.89 \mathrm{E}-(04$ & $\cdots$ & -..- & -..- & -.- \\
\hline WAST03 & 1085 & 566. & 6 & 25 & $1.64 E+05$ & 504.36 & $1.52 \mathrm{E}-(04$ & -... & $\cdots-\cdot$ & -.-. & -... \\
\hline WAST03 & 1085 & 566 & 6 & 16 & $1.05 E+05$ & 403.55 & $1.52 \mathrm{E}-() 4$ & $\cdots$ & $\cdots$ & $\cdots$ & $\cdots$ \\
\hline
\end{tabular}

Table 3. (cont'd) Morphometric and isotopic data for $N$. dutertrei from WAST03 


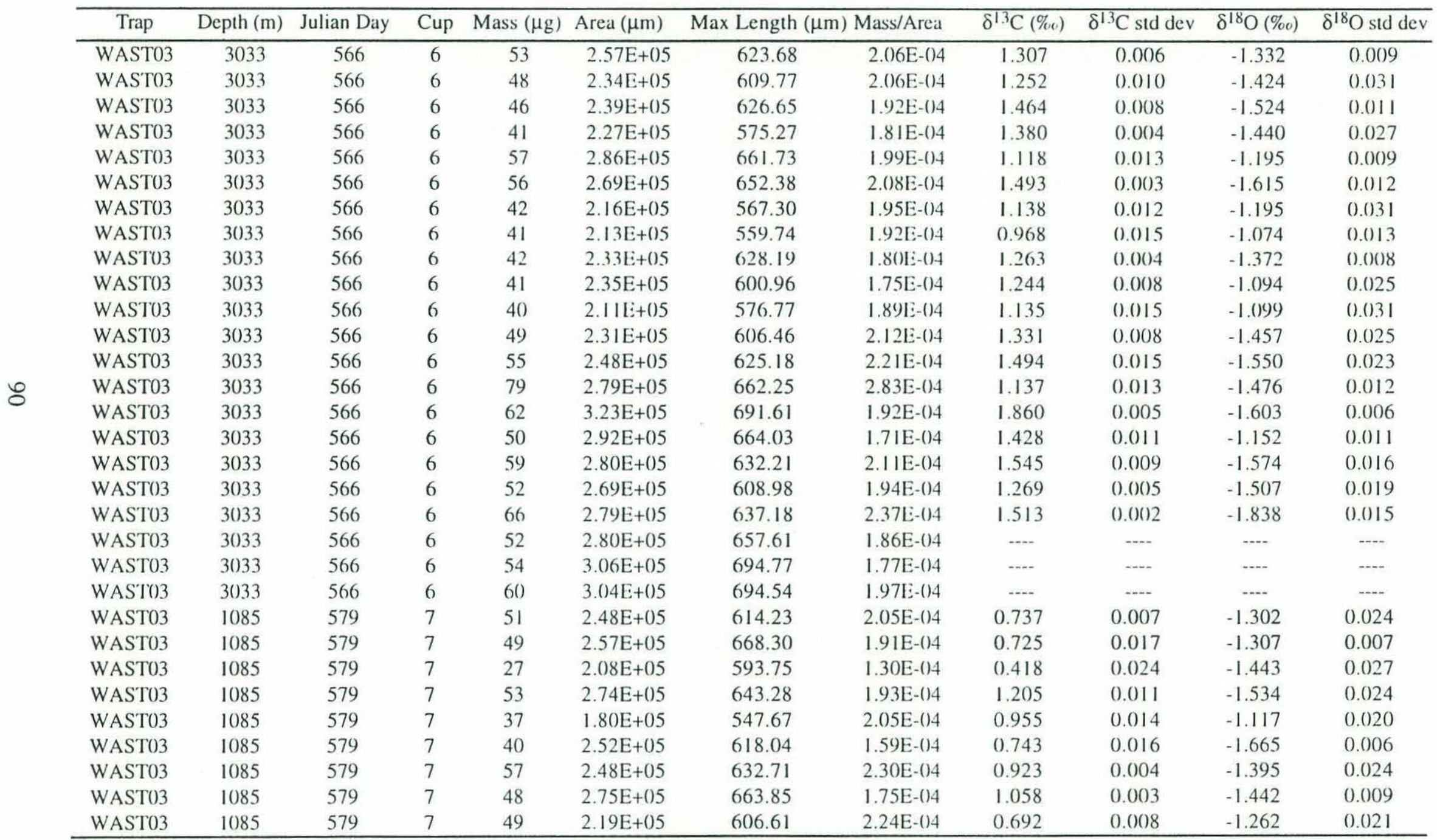

Table 3. (cont'd) Morphometric and isotopic data for $N$. dutertrei from WAST03 


\begin{tabular}{|c|c|c|c|c|c|c|c|c|c|c|c|}
\hline Trap & Depth (m) & Julian Day & Cup & Mass $(\mu \mathrm{g})$ & Area $(\mu \mathrm{m})$ & Max Length $(\mu \mathrm{m})$ & Mass/Area & $\delta^{1,3} \mathrm{C}(\%)$ & $\delta^{1,3} \mathrm{C}$ std dev & $\delta^{18} \mathrm{O}(\% 0)$ & $\delta^{18} \mathrm{O}$ std dev \\
\hline WAST03 & 1085 & 579 & 7 & 37 & $2.09 \mathrm{E}+05$ & 558.59 & $1.77 \mathrm{E}-(04$ & 1.104 & 0.007 & -1.630 & 0.020 \\
\hline WAST03 & 1085 & 579 & 7 & 48 & $2.28 \mathrm{E}+(15$ & 569.85 & 2.1IE-()4 & 0.70() & 0.015 & -1.539 & 0.028 \\
\hline WAST03 & 1085 & 579 & 7 & 44 & $2.25 E+05$ & 6() 4.89 & $1.95 \mathrm{E}-() 4$ & (0.568 & ().020 & -0.880 & 0.018 \\
\hline WAST03 & 1085 & 579 & 7 & 41 & $1.54 \mathrm{E}+05$ & 486.49 & 2.67E-(1)4 & (). 484 & 0.015 & -0.926 & 0.022 \\
\hline WAST(03 & 1085 & 579 & 7 & 28 & $1.58 E+05$ & 497.72 & $1.77 \mathrm{E}-(1) 4$ & (). 484 & 0.020 & -0.853 & 0.041 \\
\hline WAST03 & 1085 & 579 & 7 & 42 & $2.32 \mathrm{E}+05$ & 592.48 & $1.81 \mathrm{E}-(1) 4$ & 0.702 & 0.010 & -1.133 & 0.016 \\
\hline WAST03 & 1085 & 579 & 7 & 37 & $2.25 \mathrm{E}+05$ & 593.49 & 1.65E-04 & 0.739 & 0.010 & -1.365 & 0.028 \\
\hline WAST03 & 1085 & 579 & 7 & 29 & $1.46 E+05$ & 464.70 & $1.98 \mathrm{E}-() 4$ & (0.428 & 0.010 & -1.121 & (0.0)32 \\
\hline WAST03 & 1085 & 579 & 7 & 52 & $2.65 \mathrm{E}+(15)$ & 627.51 & $1.96 \mathrm{E}-() 4$ & 1.138 & 0.007 & -1.472 & 0.026 \\
\hline WAST03 & 1085 & 579 & 7 & 54 & $2.94 \mathrm{E}+05$ & 671.50 & $1.84 \mathrm{E}-(04$ & 1.439 & 0.003 & -1.513 & (0.0)11 \\
\hline WASTO3 & 1085 & 579 & 7 & 56 & $3.05 E+(05$ & 670.41 & $1.84 \mathrm{E}-(1) 4$ & 1.799 & (). .006 & -1.363 & ().015 \\
\hline WAST03 & 1085 & 579 & 7 & 50 & $2.00 \mathrm{E}+05$ & 536.72 & $2.50 \mathrm{E}-(04$ & -..- & --.. & -..- & --- \\
\hline WAST03 & 1085 & 579 & 7 & 13 & $1.53 \mathrm{E}+(05$ & 490.15 & 8.51E-(05 & $\cdots$ & .... & $\cdots$ & -... \\
\hline WAST03 & 1085 & 579 & 7 & 61 & $2.94 \mathrm{E}+05$ & 712.27 & $2.08 \mathrm{E}-(04$ & --.- & --- & $-\cdots$ & --- \\
\hline WAST03 & 1085 & 579 & 7 & 55 & $2.81 \mathrm{E}+05$ & 641.11 & $1.96 \mathrm{E}-(04$ & -..- & ---- & $\cdots$ & --- \\
\hline WAST03 & 3033 & 579 & 7 & 65 & $2.90 E+05$ & 694.11 & $2.24 \mathrm{E}-() 4$ & 1.296 & 0.004 & -1.387 & 0.020 \\
\hline WAST03 & 3033 & 579 & 7 & 38 & $2.22 \mathrm{E}+05$ & 595.33 & $1.71 \mathrm{E}-(04$ & 0.253 & 0.034 & -0.615 & 0.020 \\
\hline WAST03 & 3033 & 579 & 7 & 40 & $2.07 E+05$ & 579.92 & $1.93 \mathrm{E}-(04$ & 1.123 & 0.025 & -0.158 & 0.032 \\
\hline WAST03 & 3033 & 579 & 7 & 33 & $1.65 E+05$ & 484.53 & $2.01 \mathrm{E}-() 4$ & 0.580 & (0.016 & -1.241 & $0 .(134$ \\
\hline WAST03 & 3033 & 579 & 7 & 49 & $2.31 E+05$ & 608.88 & $2.12 E-() 4$ & 0.543 & $0 .(010$ & -1.305 & (0.()10 \\
\hline WAST03 & 3033 & 579 & 7 & 53 & $2.53 E+(05$ & 6.35 .02 & 2. $10 \mathrm{E}-(04$ & 0.886 & 0.004 & -1.352 & 0.016 \\
\hline WAST03 & 3033 & 579 & 7 & 51 & $2.56 \mathrm{E}+05$ & 610.69 & $1.99 \mathrm{E}-(04$ & 1.195 & 0.017 & -1.483 & 0.017 \\
\hline WAST03 & 3033 & 579 & 7 & 33 & $1.94 \mathrm{E}+05$ & 534.47 & $1.7(0 \mathrm{E}-(04$ & 0.696 & 0.011 & -1.141 & 0.028 \\
\hline WAST03 & 3033 & 579 & 7 & 34 & $1.83 E+05$ & 525.23 & $1.86 \mathrm{E}-(04$ & 0.548 & 0.012 & -0.415 & $0 .(040$ \\
\hline WAST03 & 3033 & 579 & 7 & 31 & $2.00 E+05$ & 548.06 & $1.55 \mathrm{E}-(04$ & (0.700 & 0.016 & -1.565 & 0.038 \\
\hline WAST03 & 3033 & 579 & 7 & 21 & $2.01 E+05$ & 546.90 & 1.05E-(04 & 2.496 & 0.010 & -1.674 & 0.040 \\
\hline WAST03 & 3033 & 579 & 7 & 49 & $2.35 E+05$ & 587.50 & 2.09E-04 & 0.941 & 0.004 & -1.478 & 0.034 \\
\hline WASTO3 & 3033 & 579 & 7 & 41 & $2.31 \mathrm{E}+(1) 5$ & 618.21 & 1.77E-(1)4 & 1.090 & $0 .(011$ & -1.356 & 0.015 \\
\hline WAST03 & 3033 & 579 & 7 & 34 & $1.95 E+05$ & 555.00 & $1.75 E-(04$ & 0.721 & 0.006 & -1.259 & 0.016 \\
\hline WAST03 & 3033 & 579 & 7 & 42 & $2.35 \mathrm{E}+05$ & 590.70 & $1.79 \mathrm{E}-04$ & 0.767 & 0.009 & -1.200 & 0.009 \\
\hline WASTO3 & 3033 & 579 & 7 & 37 & $1.9(0 \mathrm{E}+05$ & 530.68 & $1.941:-(1) 4$ & 0.636 & 0.003 & -1.158 & 0.008 \\
\hline
\end{tabular}

Table 3. (cont'd) Morphometric and isotopic data for $N$. dutertrei from WAST03 


\begin{tabular}{|c|c|c|c|c|c|c|c|c|c|c|c|}
\hline Trap & Depth (m) & Julian Day & Cup & Mass $(\mu \mathrm{g})$ & Area $(\mu \mathrm{m})$ & Max Length $(\mu \mathrm{m})$ & Mass/Area & $\delta^{1.3} \mathrm{C}(\%(c)$ & $\delta^{13} \mathrm{C}$ std dev & $\delta^{18} \mathrm{O}(\% 0)$ & $\overline{\delta^{18} \mathrm{O} \text { std dev }}$ \\
\hline WAST03 & 3033 & 579 & 7 & 27 & $1.81 \mathrm{E}+05$ & 545.43 & $1.49 \mathrm{E}-04$ & 0.780 & 0.015 & -0.938 & 0.023 \\
\hline WAST03 & 3033 & 579 & 7 & 51 & $2.56 \mathrm{E}+05$ & 621.96 & 2.0)E-(04 & 1.017 & 0.009 & -1.513 & 0.008 \\
\hline WAST03 & 3033 & 579 & 7 & 31 & $1.96 E+05$ & 540.08 & $1.58 \mathrm{E}-(1) 4$ & (). 647 & ().012 & -0.876 & (). () 48 \\
\hline WASTO3 & 3033 & 579 & 7 & 38 & 2.(1) $6 \mathrm{E}+(05$ & 561.56 & $1.85 \mathrm{E}-() 4$ & 0.985 & 0.009 & -1.145 & (). ()23 \\
\hline WAST03 & 3033 & 579 & 7 & 56 & $2.39 E+(05$ & 596.06 & $2.35 \mathrm{E}-() 4$ & 1.341 & 0.008 & -1.646 & 0.011 \\
\hline WAST03 & 3() 33 & 579 & 7 & 50 & $2.49 \mathrm{E}+() 5$ & 617.89 & 2.0()E:-(1)4 & 0.967 & $0.0(1) 5$ & -1.646 & 0.018 \\
\hline WAST03 & 3033 & 579 & 7 & 35 & $1.72 E+05$ & 518.12 & 2.(1)3E-()4 & 0.614 & 0.013 & -1.153 & (0.023 \\
\hline WAST03 & 3033 & 579 & 7 & 48 & $2.27 E+05$ & 611.36 & $2.12 \mathrm{E}-(04$ & 0.452 & 0.006 & -1.112 & 0.020 \\
\hline WAST03 & 3033 & 579 & 7 & 39 & $1.84 \mathrm{E}+05$ & 540.18 & 2.12E-()4 & (0.848 & 0.005 & -1.175 & 0.007 \\
\hline WAST03 & 3033 & 579 & 7 & 29 & $1.64 \mathrm{E}+05$ & 493.68 & $1.76 \mathrm{E}-() 4$ & 1.276 & 0.011 & -1.075 & 0.008 \\
\hline WAST03 & 3() 33 & 579 & 7 & 30 & $1.59 E+05$ & 512.50 & $1.88 \mathrm{E}-(1) 4$ & 0.735 & (0.0)14 & -0.366 & (). 026 \\
\hline WAST03 & 3033 & 579 & 7 & 32 & $1.80 \mathrm{E}+(05$ & 548.15 & $1.77 \mathrm{E}-(04$ & 0.673 & 0.012 & -0.913 & 0.029 \\
\hline WAST03 & 3033 & 579 & 7 & 54 & $2.81 \mathrm{E}+05$ & 640.16 & $1.92 \mathrm{E}-(04$ & 1.187 & 0.012 & -1.417 & (0.0)14 \\
\hline WAST03 & 3033 & 579 & 7 & 61 & $3.19 E+05$ & 680.04 & $1.91 \mathrm{E}-(1) 4$ & 1.427 & 0.007 & -1.494 & 0.024 \\
\hline WAST03 & 3033 & 579 & 7 & 56 & $3.15 E+05$ & 698.41 & $1.78 \mathrm{E}-() 4$ & 1.081 & 0.009 & -1.521 & 0.017 \\
\hline WAST03 & 3033 & 579 & 7 & 50 & $2.64 \mathrm{E}+05$ & 596.59 & 1.89E-()4 & 0.895 & 0.014 & -1.416 & 0.023 \\
\hline WAST03 & 3033 & 579 & 7 & 21 & $2.01 E+(05$ & 549.57 & $1.04 \mathrm{E}-04$ & ---- & -..- & -..- & --.- \\
\hline WAST03 & 3033 & 579 & 7 & 26 & $1.90 E+05$ & 535.48 & $1.37 \mathrm{E}-(04$ & -... & -..- & -... & -..- \\
\hline WAST03 & 3033 & 579 & 7 & 34 & --- & -... & -..- & -.-- & -.-. & $\ldots$ & -..- \\
\hline WAST03 & 3033 & 579 & 7 & 20 & $1.34 \mathrm{E}+05$ & 461.88 & 1.49E-(04 & -..- & -..- & --- & -... \\
\hline WAST03 & 1085 & 591 & 8 & 51 & $2.33 E+05$ & 592.24 & 2.19E-04 & 0.182 & 0.016 & -1.383 & 0.032 \\
\hline WAST03 & 1085 & 591 & 8 & 45 & $2.00 \mathrm{E}+05$ & 572.36 & $2.25 \mathrm{E}-(04$ & 0.290 & 0.004 & -1.233 & 0.026 \\
\hline WAST()3 & 1085 & 591 & 8 & 39 & $2.02 \mathrm{E}+05$ & 575.31 & $1.93 \mathrm{E}-(14$ & 0.591 & 0.015 & -1.084 & 0.030 \\
\hline WAST03 & 1085 & 591 & 8 & 47 & $2.34 \mathrm{E}+05$ & 597.90 & $2.00 \mathrm{E}-04$ & 0.779 & 0.009 & -1.145 & 0.020 \\
\hline WAST03 & 1085 & 591 & 8 & 38 & $2.62 \mathrm{E}+05$ & 653.99 & $1.45 \mathrm{E}-(04$ & 0.116 & 0.012 & -0.828 & 0.008 \\
\hline WAST03 & 1085 & 591 & 8 & 44 & $2.10 \mathrm{E}+05$ & 568.51 & 2.09E-(1)4 & 0.626 & 0.017 & -1.325 & 0.018 \\
\hline WAST03 & 1085 & 591 & 8 & 47 & $2.13 E+05$ & 584.26 & $2.21 \mathrm{E}-04$ & 0.641 & 0.008 & -1.044 & 0.035 \\
\hline WAST03 & 1085 & 591 & 8 & 35 & $1.83 E+05$ & 525.02 & $1.91 \mathrm{E}-(04$ & 0.631 & 0.011 & -1.280 & 0.037 \\
\hline WAST03 & 1085 & 591 & 8 & 46 & $2.65 E+05$ & 632.53 & $1.74 \mathrm{E}-() 4$ & -... & -..- & -..- & -..- \\
\hline WAST03 & 3033 & 591 & 8 & 34 & $1.87 \mathrm{E}+05$ & 546.32 & $1.82 \mathrm{E}-04$ & ().657 & 0.014 & -1.349 & 0.040 \\
\hline WAST03 & 3033 & 591 & 8 & 50 & $2.79 E+05$ & 639.50 & $1.79 \mathrm{E}-04$ & 0.495 & 0.005 & -1.415 & 0.018 \\
\hline
\end{tabular}

Table 3. (cont'd) Morphometric and isotopic data for $N$. dutertrei from WAST03 


\begin{tabular}{|c|c|c|c|c|c|c|c|c|c|c|c|}
\hline Trap & Depth (m) & Julian Day & Cup & Mass $(\mu \mathrm{g})$ & Area $(\mu \mathrm{m})$ & Max Length $(\mu \mathrm{m})$ & Mass/Area & $\delta^{13} \mathrm{C}(\%(c)$ & $\delta^{13} \mathrm{C}$ std dev & $\delta^{18} \mathrm{O}(\% o)$ & $\delta^{18} \mathrm{O}$ std dev \\
\hline WAST03 & 3033 & 591 & 8 & 25 & $1.4 .5 \mathrm{E}+(05$ & 471.15 & $1.72 \mathrm{E}-(04$ & 0.575 & 0.019 & $-1 .(043$ & 0.042 \\
\hline WAST03 & $30) 33$ & 591 & 8 & 33 & $1.83 \mathrm{E}+(05$ & 526.42 & $1.80 \mathrm{E}-(04$ & 0.347 & 0.004 & -1.301 & 0.026 \\
\hline WAST03 & 3033 & 591 & 8 & 24 & $1.61 \mathrm{E}+(05$ & 486.30 & $1.49 \mathrm{E}-(1) 4$ & 0.667 & 0.015 & -1.424 & 0.033 \\
\hline WAST03 & 3033 & 591 & 8 & 42 & $1.90 \mathrm{E}+05$ & 534.60 & $2.21 \mathrm{E}-() 4$ & 0.664 & 0.006 & -1.575 & 0.029 \\
\hline WAST03 & 3033 & 591 & 8 & 49 & $2.63 E+05$ & 647.32 & 1.86E-()4 & 0.911 & 0.015 & -1.465 & 0.031 \\
\hline WAST03 & 3033 & 591 & 8 & 38 & $2.14 \mathrm{E}+05$ & 590.46 & $1.78 \mathrm{E}-(1) 4$ & 0.526 & 0.010 & -1.392 & ().0.32 \\
\hline WAST03 & 3033 & 591 & 8 & 38 & $2.30 \mathrm{E}+(05$ & 583.67 & $1.66 \mathrm{E}-(04$ & $\cdots$ & $\cdots$ & --.- & --.. \\
\hline WAST03 & 3033 & 591 & 8 & 28 & 1. $6(0 \mathrm{E}+05$ & 507.60 & $1.75 \mathrm{E}-(04.4$ & ... & -... & --.- & $\cdots$ \\
\hline WAST03 & 3033 & 591 & 8 & 21 & $1.52 \mathrm{E}+(05$ & 509.81 & 1.38E-(04 & $-\cdots$. &.--- & --.- & $\cdots$ \\
\hline WAST03 & 1085 & 604 & 9 & 34 & $2.15 \mathrm{E}+(05$ & 573.94 & $1.58 \mathrm{E}-(14$ & 1.296 & 0.013 & -1.395 & 0.014 \\
\hline WAST03 & 1085 & 604 & 9 & 30 & $1.84 \mathrm{E}+(05$ & 545.39 & $1.63[\mathrm{E}-(04$ & 0.956 & 0.010 & -0.942 & 0.030 \\
\hline WAST03 & 1085 & 604 & 9 & 25 & $1.52 E+(05$ & 476.62 & $1.65 E-() 4$ & -... & --- & -... & $\cdots$ \\
\hline WAST03 & 1085 & $6(14$ & 9 & 22 & $1.09 \mathrm{E}+05$ & 414.64 & $2.01 \mathrm{E}-(04$ & $\cdots$ & $-\cdots$ & -..- & $-\cdots$ \\
\hline WAST03 & 3033 & 604 & 9 & 33 & $1.93 E+05$ & 538.84 & $1.71 \mathrm{E}-(04$ & 0.278 & 0.013 & -1.278 & 0.016 \\
\hline WAST03 & 3033 & $6(04$ & 9 & 37 & $2.19 \mathrm{E}+05$ & 579.97 & $1.69 \mathrm{E}-(04$ & 0.831 & 0.015 & -1.260 & 0.018 \\
\hline WAST03 & 3033 & 604 & 9 & 26 & $1.66 \mathrm{E}+05$ & 502.42 & $1.56 \mathrm{E}-(04$ & 0.359 & 0.009 & -1.363 & 0.033 \\
\hline WAST03 & 3033 & 604 & 9 & 41 & $1.76 E+05$ & 530.17 & $2.33 \mathrm{E}-() 4$ & 1.138 & 0.005 & -1.017 & 0.012 \\
\hline WAST(03 & 3033 & 604 & 9 & 21 & $1.48 E+05$ & 496.74 & $1.42 \mathrm{E}-() 4$ & $-\cdots \cdot$ & $-\cdots$ & -..- & --.- \\
\hline WAST(03 & 3033 & 604 & 9 & 28 & $1.23 \mathrm{E}+(05$ & 439.30 & $2.28 \mathrm{E}-(04$ & $\cdots$ & -... & --.. & -... \\
\hline WAST03 & 3033 & 604 & 9 & 26 & $1.33 \mathrm{E}+05$ & 444.13 & $1.95 \mathrm{E}-(04$ & $\ldots-$ & -... & $\cdots$ & --.- \\
\hline WAST03 & 1085 & 616 & 10 & 35 & $2.20 \mathrm{E}+05$ & 619.43 & $1.59 \mathrm{E}-(04$ & 1.100 & 0.014 & -1.054 & 0.016 \\
\hline WAST(03 & 1085 & 616 & 10 & 46 & $2.46 \mathrm{E}+(05$ & 633.24 & $1.87 \mathrm{E}-(04$ & 1.044 & 0.009 & -1.107 & 0.027 \\
\hline WAST03 & 1085 & 616 & 10 & 51 & $2.52 \mathrm{E}+(0) 5$ & 607.35 & 2.02E-(1)4 & 1.419 & 0.007 & -1.312 & 0.010 \\
\hline WAST03 & 1085 & 616 & 10 & 39 & $1.96 \mathrm{E}+05$ & 575.21 & $1.99 \mathrm{E}-04$ & 0.443 & 0.012 & -1.456 & 0.023 \\
\hline WAST03 & 1085 & 616 & 10 & 22 & $1.72 E+05$ & 538.30 & 1.28E-(1)4 & 1.291 & 0.031 & -1.404 & 0.031 \\
\hline WAST03 & 1085 & 616 & 10 & 36 & $1.75 E+05$ & 550.43 & $2.06 \mathrm{E}-(1) 4$ & 0.752 & 0.019 & -1.087 & 0.025 \\
\hline WAST03 & 1085 & 616 & 10 & 21 & $1.31 \mathrm{E}+05$ & 461.88 & $1.60 \mathrm{E}-(04$ & --. & -... & --- & --.. \\
\hline WAST03 & 1085 & 616 & 10 & 21 & $1.14 E+05$ & 435.58 & $1.85 \mathrm{E}-04$ & $\cdots$ & $\cdots$ & --.- & $\cdots$ \\
\hline WAST03 & 3033 & 616 & 10 & 37 & $2.27 \mathrm{E}+05$ & 600.03 & 1.63E-()4 & 0.610 & 0.011 & -1.347 & 0.020 \\
\hline WAST03 & 3033 & 616 & 10 & 31 & $1.68 \mathrm{E}+05$ & 487.72 & $1.84 \mathrm{E}-(04$ & 0.418 & 0.019 & -1.078 & 0.046 \\
\hline WAST03 & 3033 & 616 & 10 & 43 & $2.28 \mathrm{E}+05$ & 591.35 & $1.89 \mathrm{E}-(04$ & (0.165 & 0.011 & -0.861 & 0.040 \\
\hline
\end{tabular}

Table 3. (cont'd) Morphometric and isotopic data for $N$. dutertrei from WAST03 


\begin{tabular}{|c|c|c|c|c|c|c|c|c|c|c|c|}
\hline Trap & Depth (m) & Julian Day & Cup & Mass $(\mu \mathrm{g})$ & Area $(\mu \mathrm{m})$ & Max Length $(\mu \mathrm{m})$ & Mass/Area & $\delta^{13} \mathrm{C}(\%(\%)$ & $\delta^{1,3} \mathrm{C}$ std dev & $\delta^{18} \mathrm{O}(\%)$ & $\overline{\delta^{18} \mathrm{O} \text { std dev }}$ \\
\hline WAST03 & 3033 & 616 & 10 & 37 & $2.18 \mathrm{E}+05$ & 583.39 & $1.70 \mathrm{E}-(04$ & 0.663 & 0.011 & -1.247 & 0.010 \\
\hline WAST03 & 3033 & 616 & 10 & 29 & $1.66 \mathrm{E}+05$ & 520.88 & $1.75 E-(1) 4$ & 0.236 & (0.0)14 & -1.270 & (0.)(0) 4 \\
\hline WAST03 & 3033 & 616 & 10) & 29 & -... & ...- & -..- & ... & -... & $-\ldots$ & -... \\
\hline WAST03 & 3() 33 & 616 & 10) & 20 & $1.16 E+(05$ & 435.45 & $1.72 \mathrm{E}-() 4$ & .... & .... & -..- & $\ldots$ \\
\hline WASTO3 & 1085 & 629 & 11 & 30 & $1.57 \mathrm{E}+05$ & 500.75 & 1.91E-()4 & (). 5.36 & (0.010 & -0.675 & $0.0(1) 8$ \\
\hline WAST03 & 3033 & 629 & 11 & 34 & $2.05 \mathrm{E}+(05$ & 579.08 & $1.66 \mathrm{E}-() 4$ & 0.890 & 0.008 & -1.041 & 0.032 \\
\hline WAST03 & 3033 & 629 & 11 & 33 & $1.87 \mathrm{E}+05$ & 554.10 & $1.76 \mathrm{E}-(1) 4$ & $(0.691$ & 0.005 & -0.915 & (). ()28 \\
\hline WAST03 & 3033 & 629 & 11 & 32 & $1.72 E+(05$ & 497.26 & $1.86 E-() 4$ & ().655 & 0.013 & -0.790 & (0.0.37 \\
\hline WAST03 & 3033 & 629 & 11 & 31 & $1.62 \mathrm{E}+() 5$ & 491.57 & $1.91 \mathrm{E-(1)4}$ & 0.194 & (0.(0)19 & $-(0.939$ & (0.0.32 \\
\hline WASTO3 & 3033 & 641 & 12 & 35 & $1.74 \mathrm{E}+05$ & 508.65 & 2.(01E-(1)4 & (). 707 & 0.0111 & -0.782 & (0.0)18 \\
\hline WAST()3 & 3033 & 641 & 12 & 30 & $1.92 \mathrm{E}+(05$ & 537.05 & $1.57 \mathrm{E}-(1) 4$ & (). 284 & (0.0)17 & -0.958 & (0.027 \\
\hline WAST03 & 3033 & 641 & 12 & 41 & $2.09 \mathrm{E}+05$ & 587.67 & $1.96 \mathrm{E}-() 4$ & 1.538 & 0.005 & -1.489 & (0.028 \\
\hline WAST03 & 3033 & 654 & 13 & 23 & $1.32 \mathrm{E}+05$ & 434.70 & $1.74 \mathrm{E}-(04$ & 0.325 & 0.022 & -1.146 & 0.037 \\
\hline
\end{tabular}

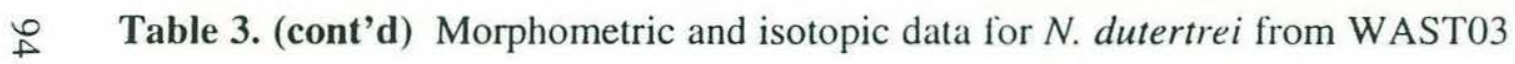




\begin{tabular}{|c|c|c|c|c|c|c|c|c|c|c|c|c|}
\hline Trap & $\begin{array}{c}\text { Depth } \\
\text { (meters) }\end{array}$ & $\begin{array}{c}\text { Julian } \\
\text { Day }\end{array}$ & Cup & $\begin{array}{c}\text { Size } \\
\text { fraction }\end{array}$ & $\begin{array}{l}\text { Mass } \\
(\mu \mathrm{g})\end{array}$ & $\begin{array}{l}\text { Area } \\
(\mu \mathrm{m})\end{array}$ & $\begin{array}{l}\text { Max Length } \\
(\mu \mathrm{m})\end{array}$ & Mass/Area & $\delta^{1.3} \mathrm{C}(\% / 6)$ & $\delta^{13} \mathrm{C}$ std dev & $\delta^{18} \mathrm{O}(\%)$ & $\delta^{18} \mathrm{O}$ std dev \\
\hline WAST01 & 3024 & 150 & 2 & 250 & 55 & $2.95 \mathrm{E}+05$ & 741.722 & $1.87 \mathrm{E}-(14$ & 2.093 & 0.011 & -1.808 & 0.034 \\
\hline WASTOI & 3024 & 163 & 3 & 250 & 48 & $1.52 \mathrm{E}+05$ & 512.814 & $3.15 \mathrm{E}-04$ & 1.203 & 0.017 & -1.918 & 0.020 \\
\hline WASTOI & 3024 & 163 & 3 & 500 & 57 & $3.04 E+05$ & 669.212 & $1.87 \mathrm{E}-(04$ & 2.405 & 0.017 & -2.030 & 0.009 \\
\hline WAST0I & 3024 & 176 & 4 & 250 & 25 & $1.76 \mathrm{E}+05$ & 569.134 & $1.42 \mathrm{E}-(04$ & 0.855 & 0.011 & -0.947 & 0.043 \\
\hline WAST0I & 3024 & 189 & 5 & 250 & 41 & $2.65 \mathrm{E}+05$ & 674.362 & $1.55 \mathrm{E}-(04$ & 1.303 & 0.006 & -2.086 & 0.016 \\
\hline WAST0I & 3024 & 189 & 5 & 250 & 33 & $2.76 \mathrm{E}+05$ & 762.581 & $1.20 \mathrm{E}-(04$ & 0.716 & 0.011 & -1.298 & 0.026 \\
\hline WAST0I & 3024 & 202 & 6 & 250 & 29 & $3.06 \mathrm{E}+05$ & 736.663 & 9.49E-()5 & 0.905 & 0.021 & -1.452 & 0.025 \\
\hline WAST()I & 3024 & 202 & 6 & 250 & 43 & $3.28 \mathrm{E}+(05$ & 764.623 & $1.31 \mathrm{E}-04$ & 1.190 & 0.012 & -1.558 & 0.011 \\
\hline WASTOI & 3024 & 202 & 6 & 250 & 23 & $2.04 \mathrm{E}+05$ & 584.004 & 1.13E-()4 & 0.724 & 0.014 & -1.300 & 0.015 \\
\hline WAST0I & 3024 & 202 & 6 & 250 & 25 & $2.20 \mathrm{E}+(0) 5$ & 622.532 & $1.14 \mathrm{E}-(04$ & 1.003 & 0.008 & -1.821 & 0.046 \\
\hline WAST()I & 3() 24 & 202 & 6 & 250 & 27 & $3.26 \mathrm{E}+() 5$ & 774.684 & $8.291 \mathrm{E}-105$ & (1).624 & ().(1)20 & -1.589 & (). ()2.3 \\
\hline WAST0I & 3024 & 202 & 6 & 500 & 68 & $5.07 \mathrm{E}+05$ & 1036.030 & $1.34 \mathrm{E}-04$ & 1.368 & 0.009 & -2.015 & 0.020 \\
\hline WAST0I & 3024 & 202 & 6 & 250 & 10 & $1.17 \mathrm{E}+05$ & 440.874 & $8.58 \mathrm{E}-(05$ & -... & -... & -... & $\cdots$ \\
\hline WASTOI & 3024 & 215 & 7 & 250 & 11 & $7.95 E+(1) 4$ & 355.877 & $1.38 \mathrm{E}-04$ & 0.196 & 0.066 & -0.669 & 0.130 \\
\hline WASTOI & 3024 & 215 & 7 & 250 & 14 & $8.79 E+04$ & 386.114 & $1.59 \mathrm{E}-(1) 4$ & (0.626 & 0.017 & -0.287 & 0.036 \\
\hline WAST01 & 3024 & 215 & 7 & 500 & 116 & $4.53 E+05$ & 993.934 & $2.56 \mathrm{E}-04$ & 2.483 & 0.007 & 0.207 & 0.023 \\
\hline WAST01 & 3024 & 215 & 7 & 500 & 82 & $4.19 \mathrm{E}+05$ & 897.624 & $1.96 \mathrm{E}-(1) 4$ & 2.458 & 0.008 & -0.152 & 0.010 \\
\hline WAST01 & 3024 & 215 & 7 & 500 & 91 & $4.66 \mathrm{E}+05$ & 900.385 & $1.95 \mathrm{E}-(04$ & 2.866 & 0.008 & -0.055 & (0.012 \\
\hline WASTOI & 3024 & 215 & 7 & 500 & 69 & $2.89 \mathrm{E}+05$ & 692.247 & $2.39 \mathrm{E}-04$ & 2.884 & 0.007 & 0.142 & 0.023 \\
\hline WAST01 & 3024 & 228 & 8 & 250 & 21 & $1.51 \mathrm{E}+05$ & 509.568 & $1.39 \mathrm{E}-(04$ & 0.687 & 0.009 & -1.036 & 0.025 \\
\hline WAST0I & 3024 & 228 & 8 & 500 & 94 & $3.80 \mathrm{E}+05$ & 837.847 & $2.47 \mathrm{E}-(1) 4$ & 2.583 & (0.0)10 & 0.317 & 0.018 \\
\hline WAST01 & 3024 & 241 & 9 & 250 & 33 & $2.09 \mathrm{E}+05$ & 596.437 & $1.58 \mathrm{E}-(04$ & 0.746 & 0.017 & -1.165 & 0.029 \\
\hline WAST01 & 3024 & 311 & 13 & 250 & 64 & $3.55 E+05$ & 827.787 & $1.80 \mathrm{E}-(04$ & 1.728 & 0.014 & -1.811 & 0.014 \\
\hline WAST01 & 3024 & 311 & 13 & 250 & 39 & $1.80 \mathrm{E}+05$ & 558.391 & $2.16 \mathrm{E}-04$ & 1.037 & 0.022 & -1.273 & 0.015 \\
\hline WAST01 & 3024 & 311 & 13 & 250 & 37 & $1.45 \mathrm{E}+05$ & 515.671 & $2.54 \mathrm{E}-04$ & 0.786 & 0.023 & -1.265 & 0.068 \\
\hline WAST01 & 3024 & 311 & 13 & 250 & 32 & $1.32 E+05$ & 452.307 & $2.42 \mathrm{E}-(04$ & (0.865 & 0.018 & -1.899 & $0 .(129$ \\
\hline WAST01 & 3024 & 311 & 13 & 250 & 44 & $1.90 \mathrm{E}+05$ & 579.551 & $2.31 \mathrm{E}-04$ & 1.629 & 0.024 & -1.716 & 0.019 \\
\hline WAST01 & 3024 & 311 & 13 & 250 & 36 & $1.48 \mathrm{E}+05$ & 507.179 & $2.44 \mathrm{E}-04$ & 1.016 & 0.011 & -1.905 & 0.031 \\
\hline
\end{tabular}

Table 4. Morphometric and isotopic data for Globigerinoides sacculifer from three Western Arabian Sea traps (WAST01, 02, 03) 


\begin{tabular}{|c|c|c|c|c|c|c|c|c|c|c|c|c|}
\hline Trap & $\begin{array}{c}\text { Depth } \\
\text { (meters) }\end{array}$ & $\begin{array}{c}\text { Julian } \\
\text { Day }\end{array}$ & Cup & $\begin{array}{c}\text { Size } \\
\text { fraction }\end{array}$ & $\begin{array}{l}\text { Mass } \\
(\mu \mathrm{g})\end{array}$ & $\begin{array}{l}\text { Area } \\
(\mu \mathrm{m})\end{array}$ & $\begin{array}{l}\text { Max Length } \\
\quad(\mu \mathrm{m})\end{array}$ & Mass/Area & $\delta^{13} \mathrm{C}(\%)$ & $\delta^{13} \mathrm{C}$ std dev & $\delta^{18} \mathrm{O}(\% \circ)$ & $\delta^{18} \mathrm{O}$ std dev \\
\hline WAST02 & 3021 & 331 & 1 & 250 & 34 & $1.28 \mathrm{E}+(05$ & 443.849 & $2.65 E-(04$ & 1.182 & 0.006 & -1.692 & 0.029 \\
\hline WAST02 & 3021 & 331 & 1 & 250 & 17 & $1.23 \mathrm{E}+05$ & 454.808 & $1.38 \mathrm{E}-04$ & 0.952 & 0.012 & -1.618 & 0.013 \\
\hline WAST02 & 3021 & 331 & 1 & 500 & 67 & $4.04 E+05$ & 840.164 & $1.66 \mathrm{E}-04$ & 2.254 & 0.009 & -2.163 & 0.010 \\
\hline WAST02 & 3021 & 331 & 1 & 500 & 64 & $3.72 E+(05$ & 842.967 & $1.72 \mathrm{E}-04$ & 2.040 & 0.003 & -2.158 & 0.023 \\
\hline WAST02 & 3021 & 331 & 1 & 5()() & 63 & $4.15 \mathrm{E}+(1) 5$ & 927.980 & $1.52 \mathrm{E}-04$ & 2.138 & 0.012 & -2.053 & 0.011 \\
\hline WAST02 & 3021 & 331 & 1 & 250 & 20 & $7.90 \mathrm{E}+04$ & 365.050 & $2.53 \mathrm{E}-04$ & $\cdots$ & -.. & -.- & --.- \\
\hline WAST02 & 3021 & 343 & 2 & 250 & 62 & $3.81 \mathrm{E}+05$ & 916.466 & $1.63 \mathrm{E}-(04$ & 2.324 & 0.004 & -2.120 & 0.011 \\
\hline WAST02 & 3021 & 343 & 2 & 250 & 16 & $1.57 \mathrm{E}+05$ & 522.981 & 1.02E-(04 & 1.004 & 0.023 & -1.569 & 0.024 \\
\hline WAST02 & 3021 & 343 & 2 & 250 & 18 & $1.59 \mathrm{E}+05$ & 557.506 & $1.13 \mathrm{E}-(04$ & 1.067 & 0.023 & -1.529 & 0.031 \\
\hline WAST02 & 3021 & 343 & 2 & 250 & 46 & $2.73 E+05$ & 696.977 & 1.69E-(04 & 1.719 & 0.012 & -2.147 & 0.016 \\
\hline WAST02 & 3021 & 343 & 2 & 250 & 61 & $4.34 \mathrm{E}+05$ & 930.739 & $1.41 \mathrm{E}-(04$ & 2.366 & 0.012 & -2.195 & 0.020 \\
\hline WAST02 & 3021 & 343 & 2 & 250 & 20 & $1.97 \mathrm{E}+05$ & 594.961 & $1.01 \mathrm{E}-04$ & 0.651 & 0.024 & -1.739 & 0.036 \\
\hline WAST02 & 3021 & 343 & 2 & 250 & 30 & $2.33 E+05$ & 649.264 & 1.29E-(04 & 1.443 & 0.021 & -1.947 & 0.034 \\
\hline WAST02 & 3021 & 343 & 2 & 250 & 27 & $2.31 \mathrm{E}+05$ & 631.296 & 1.17E-04 & 1.386 & 0.017 & -1.744 & 0.027 \\
\hline WAST02 & 3021 & 343 & 2 & 250 & 21 & $1.55 E+05$ & 529.883 & $1.36 \mathrm{E}-04$ & 0.582 & 0.031 & -1.625 & 0.027 \\
\hline WAST02 & 3021 & 343 & 2 & 250 & 20 & $1.96 \mathrm{E}+05$ & 635.951 & $1.02 \mathrm{E}-04$ & 0.926 & 0.005 & -1.704 & 0.026 \\
\hline WAST02 & 3021 & 343 & 2 & 250 & 26 & $2.16 \mathrm{E}+05$ & 606.162 & $1.20 \mathrm{E}-04$ & 1.050 & 0.017 & -1.785 & 0.037 \\
\hline WAST02 & 3021 & 343 & 2 & 250 & 14 & $1.43 E+05$ & 503.478 & 9.76E-(05 & 0.320 & 0.024 & -1.590 & 0.024 \\
\hline WAST02 & 3021 & 343 & 2 & 500 & 51 & $2.33 \mathrm{E}+05$ & 661.593 & 2.19E-04 & 1.755 & 0.013 & -2.088 & 0.008 \\
\hline WAST02 & 3021 & 343 & 2 & 500 & 72 & $3.83 \mathrm{E}+05$ & 894.966 & $1.88 \mathrm{E}-04$ & 2.225 & 0.013 & -2.147 & 0.028 \\
\hline WASTO2 & 3021 & 356 & 3 & 250 & 58 & $3.26 E+05$ & 752.912 & $1.78 \mathrm{E}-(04$ & 1.703 & 0.015 & -2.094 & (). $(120$ \\
\hline WAST02 & 3021 & 356 & 3 & 250 & 54 & $2.81 \mathrm{E}+05$ & 669.335 & $1.92 \mathrm{E}-(04$ & 1.467 & 0.008 & -2.049 & 0.022 \\
\hline WAST02 & 3021 & 356 & 3 & 250 & 20 & $1.22 \mathrm{E}+05$ & 456.031 & $1.65 \mathrm{E}-04$ & 1.073 & 0.036 & -1.934 & 0.040 \\
\hline WAST02 & 3021 & 356 & 3 & 250 & 55 & $3.42 \mathrm{E}+05$ & 824.466 & $1.61 \mathrm{E}-04$ & 1.248 & 0.007 & -2.012 & 0.011 \\
\hline WAST02 & 3021 & 356 & 3 & 500 & 56 & $5.88 \mathrm{E}+05$ & 1124.650 & $9.53 \mathrm{E}-05$ & 1.047 & 0.007 & -1.924 & 0.011 \\
\hline WAST02 & 3021 & 356 & 3 & 500 & 69 & $5.04 \mathrm{E}+05$ & 1005.210 & 1.37E-04 & 1.480 & 0.013 & -1.833 & 0.017 \\
\hline WAST02 & 3021 & 356 & 3 & 500 & 53 & $3.87 \mathrm{E}+05$ & 827.918 & 1.37E-04 & 1.158 & 0.006 & -1.928 & 0.024 \\
\hline WAST02 & 3021 & 369 & 4 & 250 & 16 & $1.31 \mathrm{IE}+05$ & 483.174 & $1.22 \mathrm{E}-04$ & 1.171 & 0.012 & -1.770 & 0.019 \\
\hline WAST02 & 3021 & 369 & 4 & 250 & 22 & $1.91 \mathrm{E}+05$ & 577.877 & $1.15 \mathrm{E}-04$ & 0.722 & 0.021 & -1.669 & 0.073 \\
\hline WAST02 & 3021 & 382 & 5 & 250 & 13 & $1.33 \mathrm{E}+05$ & 484.399 & $9.74 \mathrm{E}-05$ & 0.737 & 0.017 & -0.636 & 0.020 \\
\hline
\end{tabular}

Table 4. (cont'd) Morphometric and isotopic data for G. sacculifer from WAST02 


\begin{tabular}{|c|c|c|c|c|c|c|c|c|c|c|c|c|}
\hline Trap & $\begin{array}{c}\text { Depth } \\
\text { (meters) }\end{array}$ & $\begin{array}{l}\text { Julian } \\
\text { Day }\end{array}$ & Cup & $\begin{array}{c}\text { Size } \\
\text { fraction }\end{array}$ & $\begin{array}{l}\text { Mass } \\
(\mu \mathrm{g})\end{array}$ & $\begin{array}{l}\text { Area } \\
(\mu \mathrm{m})\end{array}$ & $\begin{array}{c}\text { Max Length } \\
(\mu \mathrm{m})\end{array}$ & Mass/Area & $\delta^{13} \mathrm{C}(\%(c)$ & $\delta^{13} \mathrm{C}$ std dev & $\delta^{18} \mathrm{O}(\%)$ & $\delta^{18} \mathrm{O}$ std dev \\
\hline WAST02 & 3021 & 382 & 5 & 250 & 33 & $1.71 E+05$ & 543.209 & $1.93 \mathrm{E}-(04$ & 1.449 & 0.023 & -0.791 & 0.063 \\
\hline WAST02 & 3021 & 382 & 5 & 250 & 16 & $1.23 E+05$ & 459.467 & $1.30 \mathrm{E}-04$ & -... & --.- & .... & -..- \\
\hline WAST02 & 3021 & 395 & 6 & 250 & 20 & $1.40 E+05$ & 490.968 & $1.42 \mathrm{E}-04$ & (0.873 & ().()20 & -1.185 & 0.033 \\
\hline WAST02 & 3021 & 395 & 6 & 250 & 22 & $1.65 E+05$ & 512.150 & $1.33 \mathrm{E}-() 4$ & 0.704 & 0.017 & -1.385 & 0.032 \\
\hline WAST02 & 3021 & 395 & 6 & 5() 0 & 46 & $3.50 \mathrm{E}+(05$ & 801.571 & $1.31 \mathrm{E}-(04$ & 1.377 & 0.007 & -1.529 & 0.004 \\
\hline WAST03 & 3033 & 541 & 4 & 250 & 40 & $2.81 \mathrm{E}+(05$ & 692.358 & $1.42 \mathrm{E}-() 4$ & 1.822 & 0.016 & -2.044 & 0.030 \\
\hline WAST03 & 3033 & 541 & 4 & 250 & 21 & $1.35 E+05$ & 483.740 & $1.56 \mathrm{E}-04$ & 1.588 & 0.007 & -2.205 & 0.033 \\
\hline WAST03 & 3033 & 541 & 4 & 250 & 44 & $2.84 E+(15$ & 700.889 & $1.55 \mathrm{E}-(04$ & 1.464 & (0.0)15 & -1.891 & ().013 \\
\hline WAST03 & 3033 & 541 & 4 & 250 & 46 & $2.78 E+05$ & 689.392 & 1.66E-()4 & 1.394 & 0.013 & -2.529 & 0.009 \\
\hline WAST(03 & 3033 & 541 & 4 & 500 & 77 & $4.24 E+(05$ & 841.863 & $1.82 \mathrm{E}-(04$ & 2.324 & 0.010 & -2.235 & 0.018 \\
\hline WAST03 & 3033 & 541 & 4 & 500 & 80 & $5.29 \mathrm{E}+05$ & 1028.000 & $1.51 \mathrm{E}-(04$ & 2.199 & 0.009 & -2.020 & (0.0)15 \\
\hline WAST03 & 3033 & 541 & 4 & 500 & 84 & $4.95 E+05$ & 943.102 & $1.70 \mathrm{E}-04$ & 2.417 & 0.003 & -2.167 & 0.004 \\
\hline WAST03 & 3033 & 541 & 4 & 500 & 56 & $3.59 \mathrm{E}+05$ & 858.744 & $1.56 \mathrm{E}-04$ & 1.762 & 0.006 & -2.026 & 0.011 \\
\hline WAST03 & 3033 & 541 & 4 & 500 & 68 & $4.14 E+05$ & 819.630 & $1.64 \mathrm{E}-(04$ & 1.914 & 0.007 & -2.456 & 0.013 \\
\hline WAST03 & 3033 & 541 & 4 & 500 & 20 & $1.43 \mathrm{E}+05$ & 482.265 & $1.40 \mathrm{E}-(04$ & 2.043 & 0.018 & -2.478 & 0.025 \\
\hline WAST03 & 3033 & 541 & 4 & 250 & 8 & $9.21 \mathrm{E}+04$ & 395.669 & $8.68 \mathrm{E}-05$ & --.- & -..- & -..- & ---- \\
\hline WAST03 & 3033 & 554 & 5 & 500 & 62 & $3.67 \mathrm{E}+05$ & 826.661 & $1.69 \mathrm{E}-04$ & 2.033 & 0.008 & -2.121 & 0.008 \\
\hline WAST03 & 3033 & 566 & 6 & 250 & 60 & $3.35 E+05$ & 817.741 & 1.79E-(04 & 1.553 & 0.011 & -1.943 & 0.019 \\
\hline WAST03 & 3033 & 566 & 6 & 250 & 45 & $2.36 \mathrm{E}+05$ & 685.633 & $1.91 \mathrm{E}-(04$ & 0.784 & 0.016 & -1.600 & 0.042 \\
\hline WAST03 & 3033 & 566 & 6 & 500 & 38 & $1.64 \mathrm{E}+05$ & 567.687 & $2.32 \mathrm{E}-() 4$ & 1.336 & 0.017 & -1.257 & $0 .(1) 42$ \\
\hline WAST03 & 3033 & 566 & 6 & 500 & 58 & $2.68 E+(15$ & 663.767 & $2.17 \mathrm{E}-04$ & -... & -.-- & -.-- & -..- \\
\hline WASTO3 & 3033 & 579 & 7 & 250 & 28 & $1.19 \mathrm{E}+05$ & 465.445 & $2.36 \mathrm{E}-(04$ & 0.634 & 0.064 & -1.160 & 0.068 \\
\hline WAST03 & 3033 & 579 & 7 & 250 & 49 & $2.64 \mathrm{E}+05$ & 676.499 & $1.86 \mathrm{E}-04$ & 1.200 & 0.035 & -1.635 & 0.042 \\
\hline WAST03 & 3033 & 579 & 7 & 250 & 35 & $1.92 \mathrm{E}+05$ & 624.019 & $1.82 \mathrm{E}-() 4$ & 0.511 & (0.049 & -1.766 & 0.059 \\
\hline WASI().3 & 30.33 & 579 & 7 & 250 & 46 & $2.52 \mathrm{~L}+1) 5$ & 677.255 & 1.82L-(14 & 0.615 & (). (1) 30 & -1.744 & (). 052 \\
\hline WAST03 & 3033 & 579 & 7 & 250 & 27 & $9.46 \mathrm{E}+04$ & 381.665 & $2.86 \mathrm{E}-04$ & -0.094 & 0.042 & -3.202 & 0.199 \\
\hline WAST03 & 3033 & 579 & 7 & 250 & 57. & $1.87 \mathrm{E}+05$ & 556.263 & 3.05E-(04 & 1.909 & 0.039 & -2.243 & 0.068 \\
\hline WAST03 & 3033 & 579 & 7 & 500 & 88 & $3.96 E+05$ & 839.667 & 2.22E-(04 & 1.666 & 0.006 & -1.958 & 0.014 \\
\hline WAST03 & 3033 & 579 & 7 & 500 & 90 & $4.13 E+05$ & 945.884 & $2.18 \mathrm{E}-04$ & 1.423 & 0.010 & -2.165 & 0.018 \\
\hline
\end{tabular}

Table 4. (cont'd) Morphometric and isotopic data for G. sacculifer from WAST02 and WAST03 


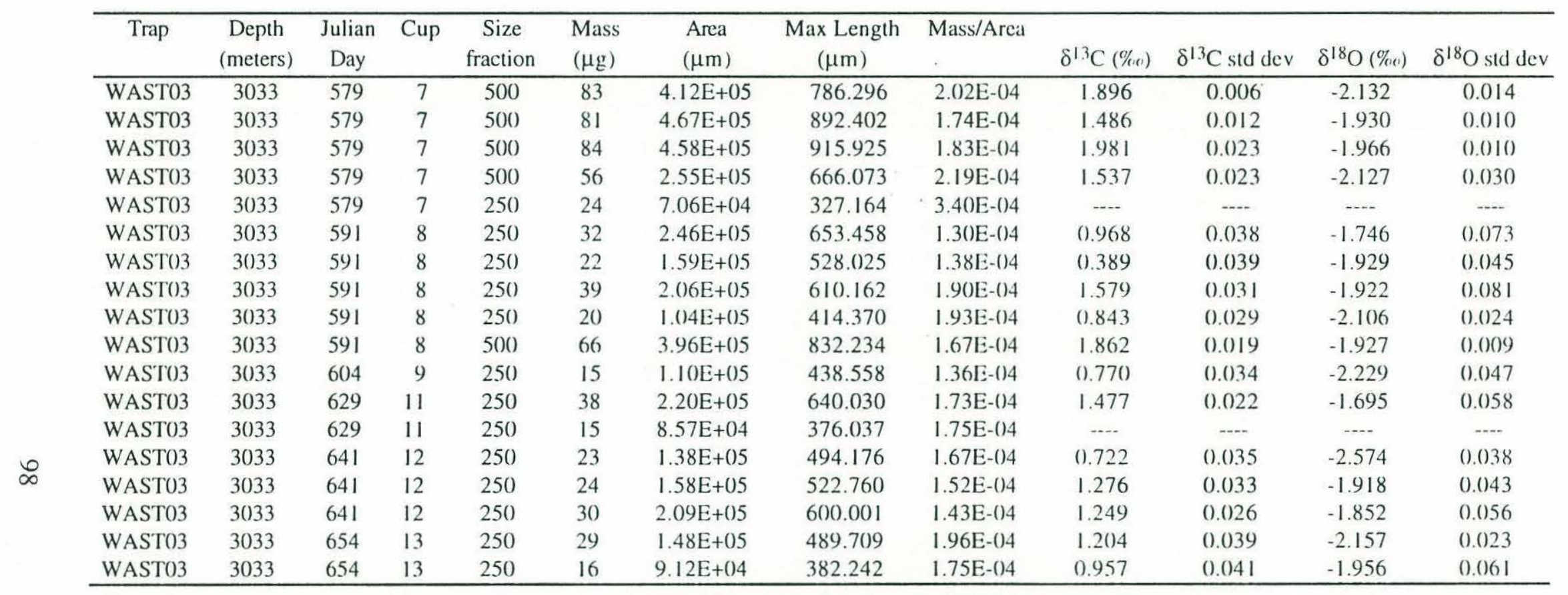

Table 4. (cont'd) Morphometric and isotopic data for G. sacculifer from WAST03 


\begin{tabular}{|c|c|c|c|c|c|c|c|c|c|c|c|c|}
\hline Trap & $\begin{array}{c}\text { Depth } \\
\text { (meters) }\end{array}$ & $\begin{array}{c}\text { Julian } \\
\text { Day }\end{array}$ & Cup & $\begin{array}{c}\text { Size } \\
\text { fraction }\end{array}$ & $\begin{array}{l}\text { Mass } \\
(\mu g)\end{array}$ & $\begin{array}{l}\text { Area } \\
(\mu \mathrm{m})\end{array}$ & $\begin{array}{l}\text { Max Length } \\
(\mu \mathrm{m})\end{array}$ & Mass/Area & $\delta^{1,3} \mathrm{C}(\%(c)$ & $\delta^{13} \mathrm{C}$ std dev & $\delta^{18} \mathrm{O}(\%(\%)$ & $\delta^{18} \mathrm{O}$ std dev \\
\hline WAST01 & 3024 & 189 & 5 & 250 & 10 & 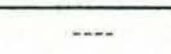 & $\ldots$ & $\ldots$ & -2.348 & 0.071 & -2.357 & 0.130 \\
\hline WAST01 & 3024 & 189 & 5 & 250 & 13 & $-\cdots$ & $\cdots$ & -... & -1.740 & 0.054 & -2.112 & 0.095 \\
\hline WAST0I & 3024 & 189 & 5 & 250 & 22 & $\cdots$ & $\cdots$ & $\cdots$ & -1.485 & 0.062 & -2.266 & 0.099 \\
\hline WAST01 & 3024 & 189 & 5 & 250 & 22 & ---. & $-\cdots$ & -... & -1.891 & 0.044 & -2.261 & 0.077 \\
\hline WAST(01 & 3024 & 189 & 5 & 250 & 18 & -..- & --- & --- & -2.546 & 0.019 & -2.768 & 0.029 \\
\hline WAST0I & 3024 & 189 & 5 & 250 & 16 & $\cdots$ & -.-- & $\cdots$ & -3.015 & (0.069 & -3.987 & 0.148 \\
\hline WAST01 & 3024 & 189 & 5 & 250 & 25 & $-\cdots$ & $-\cdots$ & $\ldots$ & -1.575 & 0.064 & -1.678 & 0.052 \\
\hline WAST01 & 3024 & 189 & 5 & 250 & 22 & -.- & --.- & -- & -1.752 & (). 052 & -2.307 & 0.118 \\
\hline WAST01 & 3024 & 202 & 6 & 250 & 34 & $1.32 \mathrm{E}+05$ & 457.48 & $2.57 \mathrm{E}-04$ & (). 147 & (0.011 & -0.909 & 0.060 \\
\hline WAST01 & 3024 & 202 & 6 & 250 & 26 & $1.26 \mathrm{E}+05$ & 468.79 & $2.06 \mathrm{E}-04$ & -1.226 & (0.034 & -1.253 & (0.102 \\
\hline WAST01 & 3024 & 202 & 6 & 250 & 27 & $1.63 E+05$ & 526.96 & $1.66 \mathrm{E}-(04$ & -0.697 & 0.026 & -0.369 & 0.057 \\
\hline WAST0I & 3024 & 202 & 6 & 250 & 30 & $1.51 \mathrm{E}+05$ & 524.00 & $1.98 \mathrm{E}-04$ & -2.023 & 0.025 & -1.444 & (0.044 \\
\hline WAST01 & 3024 & 202 & 6 & 250 & 27 & $1.45 \mathrm{E}+05$ & 500.28 & $1.86 \mathrm{E}-() 4$ & -1.153 & (0.030 & -0.707 & (0.031 \\
\hline WAST01 & 3024 & 202 & 6 & 250 & -... & -..- & -..- & -..- & -1.100 & 0.039 & -0.809 & 0.048 \\
\hline WAST0I & 3024 & 202 & 6 & 250 & 29 & $1.57 \mathrm{E}+05$ & 512.88 & $1.85 \mathrm{E}-(04$ & -1.180 & 0.018 & -1.065 & 0.038 \\
\hline WAST01 & 3024 & 202 & 6 & 250 & -... & -..- & -..- & -..- & -0.821 & 0.080 & -0.172 & 0.064 \\
\hline WAST()I & 3024 & 202 & 6 & 250 & 27 & 1. $35 E+05$ & 503.23 & 2.01E-04 & -1.202 & 0.073 & -1.084 & 0.066 \\
\hline WAST0I & 3024 & 202 & 6 & 250 & 28 & $1.24 \mathrm{E}+05$ & 460.25 & $2.26 \mathrm{E}-04$ & -1.240 & 0.075 & -0.880 & 0.144 \\
\hline WASTOI & 3024 & 202 & 6 & 250 & 30 & $1.40 \mathrm{E}+05$ & 471.85 & $2.14 \mathrm{E}-(1) 4$ & -1.312 & 0.018 & -0.824 & 0.022 \\
\hline WASTOI & 3() 24 & 202 & 6 & 250 & 30 & $1.41 \mathrm{E}+05$ & 481.24 & $2.13 \mathrm{E}-(04$ & -1.104 & 0.037 & -0.950 & 0.067 \\
\hline WAST0I & 3024 & 202 & 6 & 250 & 34 & $1.61 \mathrm{E}+05$ & 564.91 & $2.11 \mathrm{E}-04$ & -1.685 & 0.026 & -1.377 & 0.042 \\
\hline WAST0I & 3024 & 202 & 6 & 250 & 23 & -... & .... & -... & -1.280 & 0.059 & -1.359 & 0.083 \\
\hline WAST0I & 3024 & 202 & 6 & 250 & 25 & -.-- & --.. & -.-- & -1.426 & 0.025 & -1.156 & 0.091 \\
\hline WAST01 & 3024 & 202 & 6 & 250 & 26 & -..- & --- & --- & -1.805 & 0.060 & -2.060 & 0.023 \\
\hline WAST01 & 3024 & 202 & 6 & 250 & 26 & --- & --- & --- & -1.652 & 0.029 & -1.548 & 0.066 \\
\hline WAST01 & 3024 & 202 & 6 & 250 & 19 & -... & -... & -..- & -2.258 & 0.056 & -1.975 & 0.110 \\
\hline WASTOI & 3024 & 202 & 6 & 250 & 21 & $-\cdots$ & --- &.-- & -2.050 & 0.029 & -1.812 & 0.044 \\
\hline WASTOI & 3024 & 202 & 6 & 250 & 23 & -..- & $\cdots$ & $\cdots$ & -1.608 & 0.068 & -2.400 & 0.110 \\
\hline WAST01 & 3024 & 202 & 6 & 250 & 31 & -... & -..- & $-\cdots$ & -1.852 & 0.024 & -1.549 & 0.035 \\
\hline WAST01 & 3024 & 202 & 6 & 250 & 23 & --- & $\cdots$ & $\cdots$ & -2.282 & (0.044 & -1.640 & 0.113 \\
\hline
\end{tabular}

Table 5. Morphometric and isotopic data for Globigerina bulloides from three Western Arabian Sea traps (WAST01, 02, 03) 


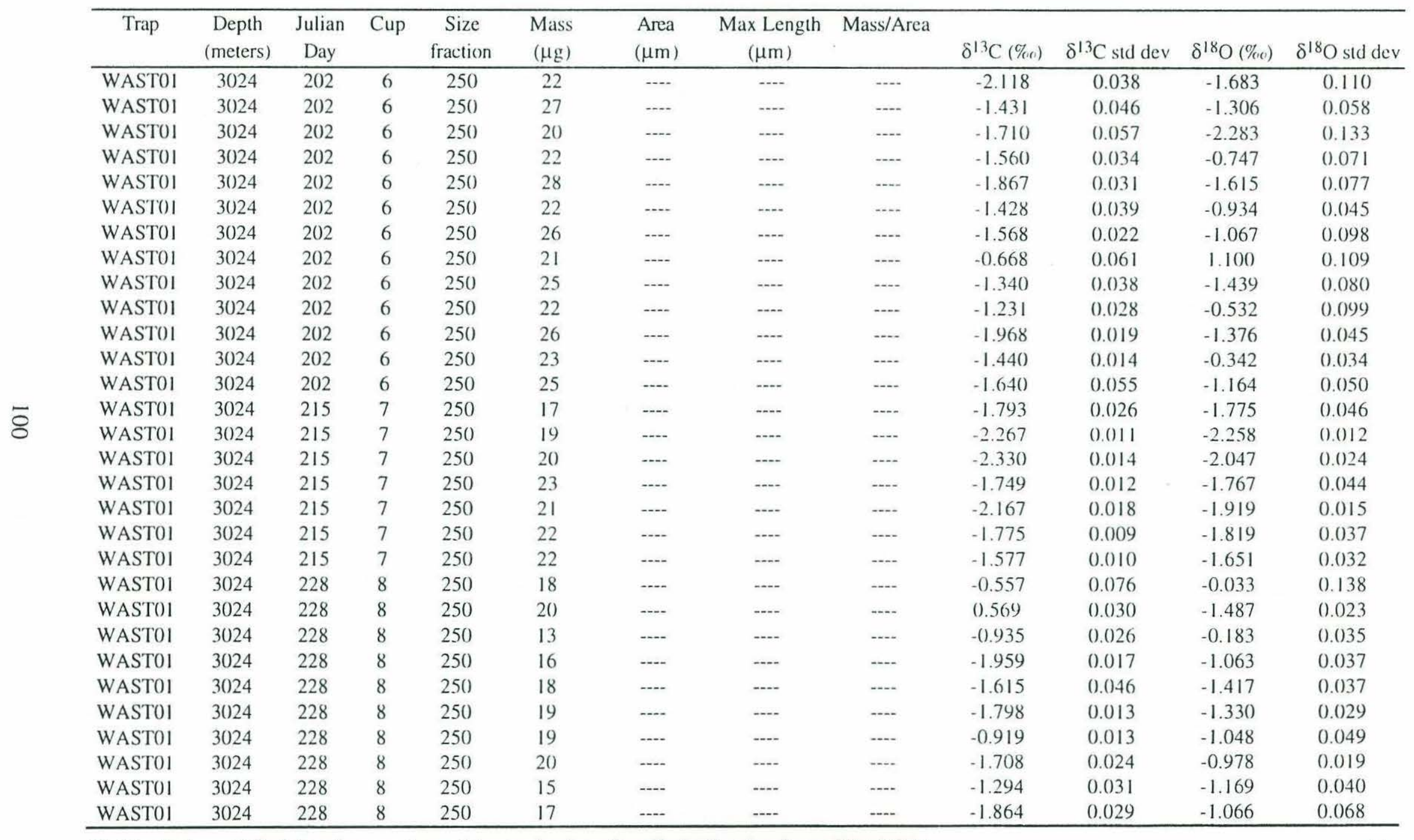

Table 5. (cont'd) Morphometric and isotopic data for G. bulloides from WAST01 


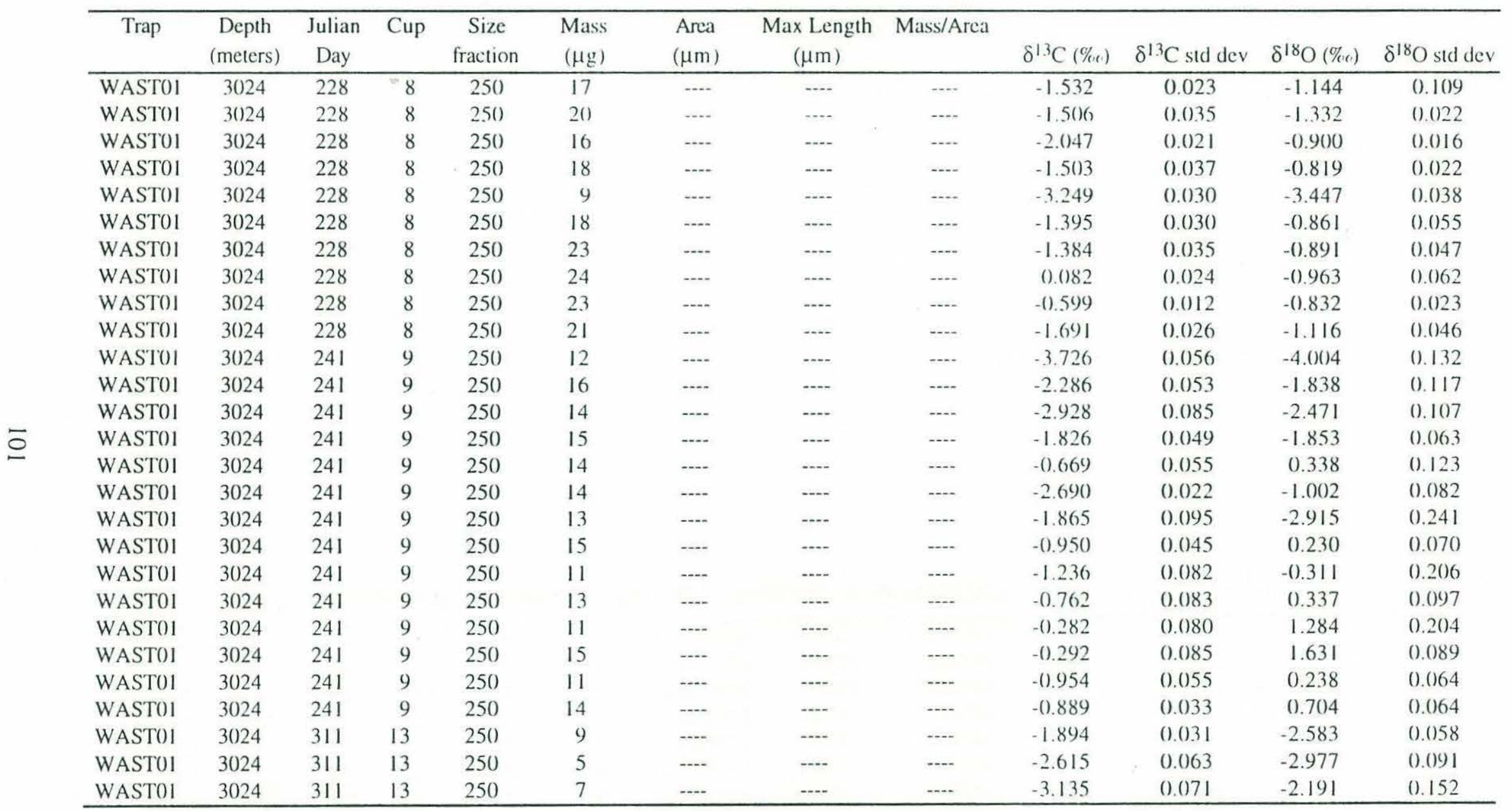

Table 5. (cont'd) Morphometric and isotopic data for G. bulloides from WAST01 


\begin{tabular}{|c|c|c|c|c|c|c|c|c|c|c|c|c|}
\hline Trap & $\begin{array}{c}\text { Depth } \\
\text { (meters) }\end{array}$ & $\begin{array}{c}\text { Julian } \\
\text { Day }\end{array}$ & Cup & $\begin{array}{c}\text { Size } \\
\text { fraction }\end{array}$ & $\begin{array}{l}\text { Mass } \\
(\mu \mathrm{g})\end{array}$ & $\begin{array}{l}\text { Area } \\
(\mu \mathrm{m})\end{array}$ & $\begin{array}{l}\text { Max Length } \\
\qquad(\mu \mathrm{m})\end{array}$ & Mass/Area & $\delta^{13} \mathrm{C}(\%(\%)$ & $\delta^{13} \mathrm{C}$ std dev & $\delta^{18} \mathrm{O}(\%(\%)$ & $\delta^{18} \mathrm{O}$ std dev \\
\hline WAST02 & 3021 & 343 & 2 & 250 & 13 & $1.44 \mathrm{E}+05$ & 495.81 & 9.02E-(1)5 & -..- & $\cdots$ & --- & --.- \\
\hline WAST02 & 3021 & 343 & 2 & 250 & 15 & $1.77 \mathrm{E}+05$ & 57.3 .25 & $8.47 \mathrm{E}-(05$ & -... & .... & $\cdots$ & -... \\
\hline WAST02 & 3021 & 343 & 2 & 250 & 10 & $1.22 \mathrm{E}+(05$ & 429.56 & $8.17 \mathrm{E}-(05$ & $\cdots$. & $\cdots$ & $\cdots$ & -... \\
\hline WASTO2 & 3() 21 & 369 & 4 & 250 & 10 & $8.39 \mathrm{E}+(1) 4$ & 373.20 & 1.19E-(04 & -..- & .... & 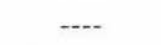 & -... \\
\hline WAST(1)2 & 3() 21 & 382 & 5 & 250 & 10) & $9.16 \mathrm{E}+(04$ & 395.74 & 1.091:-(1)4 & $\cdots$ & --.. & $\cdots$ & --.- \\
\hline WAST(02 & 3021 & 382 & 5 & 250 & 10) & $8.60 \mathrm{E}+(04$ & 390.59 & $1.16 \mathrm{E}-(04)$ & $\ldots$ & -..- & -... & -..- \\
\hline WAST02 & 3021 & 382 & 5 & 250 & 11 & $1.02 \mathrm{E}+(05$ & 407.53 & $1.08 \mathrm{E}-(04$ & --. & --- & --- & --.. \\
\hline WAST(1) 2 & 3021 & 382 & 5 & 25() & 12 & 1.02E+(1)5 & 4.30 .45 & $1.18 \mathrm{E}-(04$ & $\cdots$ & --.. & -... & $\cdots$ \\
\hline WAST()2 & $302 \mathrm{I}$ & 382 & 5 & 250 & 10 & $8.60 \mathrm{E}+(1) 4$ & 367.64 & $1.16 \mathrm{E}-(04$ & $\cdots$ & $\cdots$. & $\cdots$ & -..- \\
\hline WAST02 & 3021 & 395 & 6 & 250 & 10) & $9.58 E+(04$ & 423.04 & $1.04 \mathrm{E}-04$ & $\cdots \cdot$ & $\cdots$ & $\cdots$ & $\cdots$ \\
\hline WAST'() 2 & 3021 & 407 & 7 & 250 & 10 & $1.02 \mathrm{E}+(05$ & 417.01 & $9.83 \mathrm{E}-(0.5$ & $\cdots$ & $\cdots$ & $\cdots$ & $\cdots$ \\
\hline
\end{tabular}

Table 5. (cont'd) Morphometric and isotopic data for G. bulloides from WAST02 


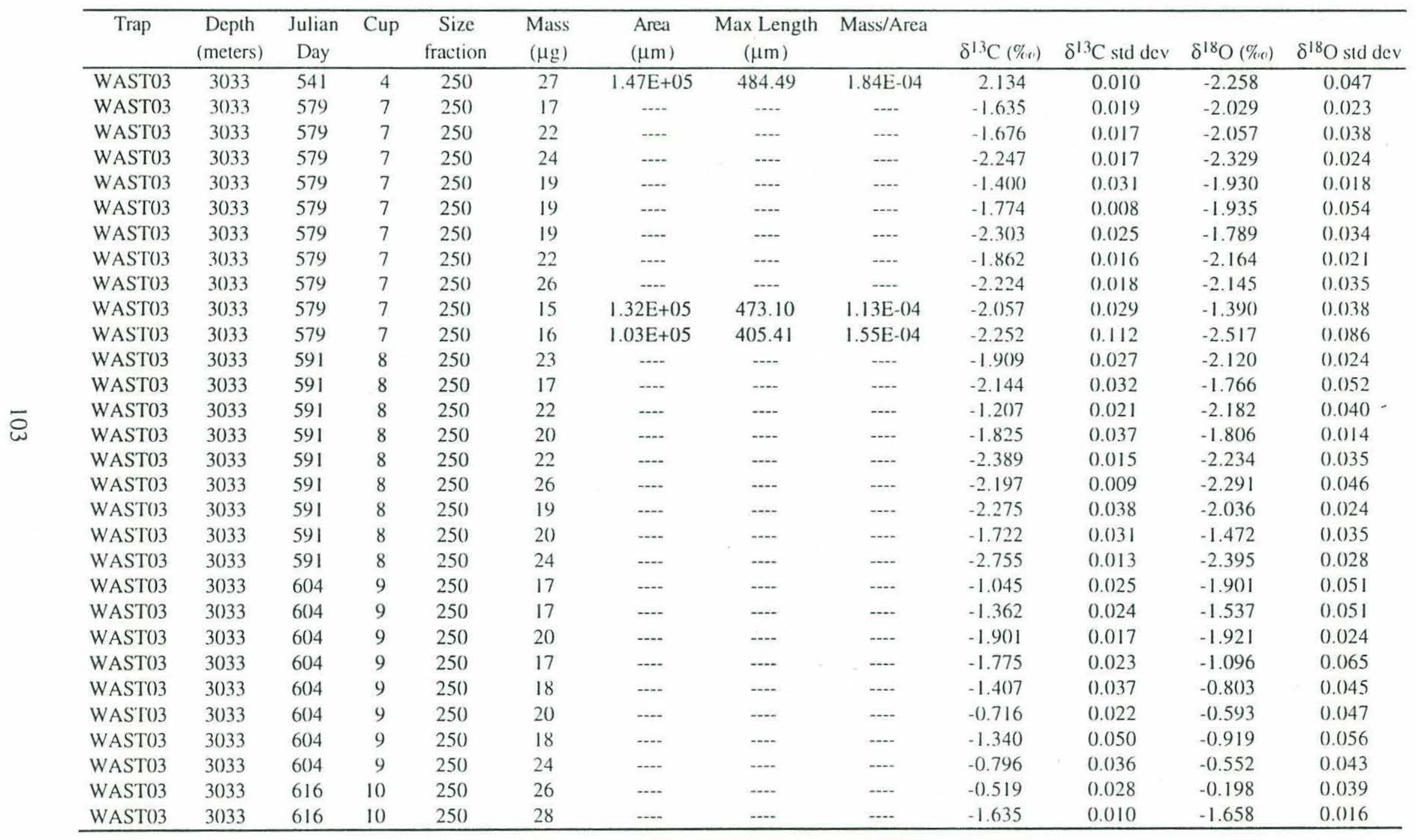

Table 5. (cont'd) Morphometric and isotopic data for G. bulloides from WAST03 


\begin{tabular}{|c|c|c|c|c|c|c|c|c|c|c|c|c|}
\hline Trap & $\begin{array}{c}\begin{array}{c}\text { Depth } \\
\text { (meters) }\end{array} \\
\end{array}$ & $\begin{array}{c}\text { Julian } \\
\text { Day }\end{array}$ & Cup & $\begin{array}{c}\text { Size } \\
\text { fraction }\end{array}$ & $\begin{array}{l}\text { Mass } \\
(\mu \mathrm{g}) \\
\end{array}$ & $\begin{array}{l}\text { Area } \\
(\mu \mathrm{m})\end{array}$ & $\begin{array}{l}\text { Max Length } \\
(\mu \mathrm{m})\end{array}$ & Mass/Area & $\delta^{1.3} \mathrm{C}(\%(c)$ & $\delta^{13} \mathrm{C}$ std dev & $\delta^{18} \mathrm{O}(\%)$ & $\delta^{18} \mathrm{O}$ std dev \\
\hline WAST03 & 3033 & 616 & 10 & 250 & 27 & $-\cdots-$ & -..- & $\cdots$ & -1.210 & 0.033 & -1.347 & 0.057 \\
\hline WAST03 & 3033 & 616 & 10 & 250 & 23 & -... & ... & -... & -1.586 & 0.010 & -1.585 & 0.027 \\
\hline WAST03 & 3033 & 616 & 10 & 250 & 26 & -..- & -..- & -... & -1.312 & 0.029 & -1.386 & 0.026 \\
\hline WAST03 & 3033 & 616 & 10 & 250 & 27 & -.- & $\cdots$ &.-- & -1.202 & 0.031 & -1.285 & 0.015 \\
\hline WAST()3 & 3033 & 616 & 10 & 250 & 24 & $\cdots$ & -..- & -..- & -1.30() & 0.097 & -0.913 & 0.160 \\
\hline WASTO3 & 3033 & 616 & 10 & 250 & 22 & -..- & -... & -..- & -0.913 & 0.029 & -0.656 & 0.066 \\
\hline WAST03 & 3033 & 616 & 10 & 250 & 15 & $1.19 E+05$ & 447.06 & $1.26 \mathrm{E}-04$ & -2.762 & 0.172 & -4.112 & 0.050 \\
\hline WAST03 & 3033 & 616 & 10 & 250 & 19 & $1.46 \mathrm{E}+05$ & 521.49 & $1.30 \mathrm{E}-04$ & 0.178 & 0.021 & 0.645 & 0.021 \\
\hline WAST03 & 3033 & 629 & 11 & 250 & 16 & $1.96 \mathrm{E}+05$ & 607.29 & $8.16 \mathrm{E}-05$ & -0.391 & 0.015 & -0.514 & 0.025 \\
\hline WAST03 & 3033 & 629 & 11 & 250 & 17 & $1.25 \mathrm{E}+05$ & 494.02 & 1.35E-()4 & 1.039 & 0.050 & -1.559 & 0.127 \\
\hline WAST03 & 3033 & 629 & 11 & 250 & 25 & -... & -... & -..- & -1.232 & 0.021 & -1.410 & 0.044 \\
\hline WAST03 & 3033 & 629 & 11 & 250 & 22 & -... & .... & .... & -1.437 & 0.040 & -1.590 & 0.057 \\
\hline WAST03 & 3033 & 629 & 11 & 250 & 21 & 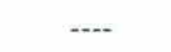 & -..- & -..- & -1.415 & 0.015 & -1.384 & 0.033 \\
\hline WAST03 & 3033 & 629 & 11 & 250 & 21 & $-\cdots$ & -.- & $\cdots$ & -1.315 & 0.014 & -1.442 & 0.050 \\
\hline WAST03 & 3033 & 629 & 11 & 250 & 17 & $\cdots$ & -..- & $\ldots$ & -1.014 & 0.015 & -0.768 & 0.066 \\
\hline WAST03 & 3033 & 629 & 11 & 250 & 22 & --.- & -.-. & $\cdots$ & -0.844 & 0.036 & -0.271 & 0.026 \\
\hline WAST03 & 3033 & 629 & 11 & 250 & 20 & $\cdots$ & $\cdots$ & $\cdots$ & -1.363 & 0.037 & -0.522 & 0.051 \\
\hline WAST03 & 3033 & 629 & 11 & 250 & 25 & --. & --- & --.- & -0.841 & 0.018 & -0.269 & 0.044 \\
\hline WAST03 & 3033 & 641 & 12 & 250 & 16 & --.- & --- & --. & -1.761 & 0.078 & -1.870 & 0.146 \\
\hline WAST03 & 3033 & 641 & 12 & 250 & 14 & -... & $\cdots$ & $\cdots$ & -0.988 & 0.036 & -0.498 & 0.069 \\
\hline WAST03 & 3033 & 641 & 12 & 250 & 18 & -.-- & $\ldots$ & -..- & -1.382 & 0.034 & -0.865 & 0.131 \\
\hline WAST03 & 3033 & 641 & 12 & 250 & 26 & -..- & --- & -..- & -1.756 & 0.011 & -2.048 & 0.041 \\
\hline WAST03 & 3033 & 654 & 13 & 250 & 17 & -.-- & --- & --. & -1.050 & 0.050 & -0.957 & 0.054 \\
\hline WAST03 & 3033 & 654 & 13 & 250 & 15 & -.- & $\cdots$ & --. & -1.351 & 0.028 & -1.002 & 0.043 \\
\hline WAST03 & 3033 & 654 & 13 & 250 & 21 & $\cdots$ & --.. & $\cdots$ & -1.955 & 0.026 & -1.292 & 0.036 \\
\hline WAST03 & 3033 & 654 & 13 & 250 & 18 & $-\cdots$ & $-\cdots$ & $--\cdot$ & -2.247 & 0.105 & -2.082 & 0.203 \\
\hline
\end{tabular}

Table 5. (cont'd) Morphometric and isotopic data for G. bulloides from WAST03 
APPENDICES 


\section{APPENDIX A}

SOURCES OF SEA SURFACE TEMPERATURE DATA AND WATER COLUMN DATA

Hydrographic data for this study came from several sources. Real-time sea surface temperatures (May 1986 to October 1987) are from the Advanced Very High Resolution Radiometer Multichannel Sea Surface Temperature satellite data set (AVHRR-MCSST). The AVHRR is a radiation detection imager that uses five detectors to collect different bands of radiation wavelengths. One channel monitors energy in the visible band, and another channel monitors energy in the near-infrared portion of the electromagnetic spectrum to observe vegetation. clouds, lakes, shorelines, snow, and ice. The other three channels operate entirely within the infrared band to detect the heat radiation from land, water, sea surfaces, and the clouds above them. The AVHRR Multichannel Sea Surface Temperature satellite raw data was processed at The University of Miami. Rosenstiel School of Marine and Atmospheric Science, and is available through the NASA Ocean Data System at the Jet Propulsion Laboratory (JPL). After processing, hydrologic, oceanographic, and meteorological parameters can be defined. Weekly averages of SST are calculated, and interpolated if necessary, using the satellite observations [SMITH. 1992].

Water column data for this study came from two sources, the 1994 World Ocean Atlas and the Geochemical Ocean Sections (GEOSECS) expedition results. The World Ocean Atlas 1994 data set (WOA 94) consists of a synthesis of temperature. salinity, oxygen and nutrients in the world ocean. It was prepared by Sydney Levitus. Timothy Boyer, Russell Burgett, and Margarita Conkright of the National Oceanographic Data Center (NODC) as a continuation of the 1982 Climatological Atlas compiled by Levitus. Ocean parameters have been analyzed on a one-degree latitude-longitude grid between the surface and ocean bottom [CONKRIGHT, 1994; LEVITUS, 1994]. Monthly means of water column temperature and salinity were obtained for an area between $10-20^{\circ} \mathrm{N}$ latitude and 55-65 E longitude using [http://ferret.wrc.noaa.gov/fbin/climate_server], which is a World Wide Web (WWW) visualization and data extraction server accessing the NOAA Pacific Marine Environmental Laboratory's gridded, climate data base [HANKIN, 1992]. This area was selected because it gives data for a localized region around the western Arabian Sea sediment trap ( $16^{\circ} 19^{\prime} \mathrm{N}$ latitude and $60^{\circ} 28^{\prime} \mathrm{E}$ longitude), yet contains a sufficient number of data points to represent the overall hydrography. 